\title{
Húrrezgések megfigyelési problémáinak vizsgálata
}

\author{
Doktori értekezés
}

\author{
SZIJÁRTÓ ANDRÁS LAJOS
}

Témavezető:

Dr. Móricz FerenC

Konzulens:

DR. HEGEDÚs JENÓ

Matematika- és Számítástudományok Doktori Iskola Szegedi Tudományegyetem

Természettudományi és Informatikai Kar

Bolyai Intézet

Szeged

2016 


\section{Tartalomjegyzék}

1. Bevezetés 2

1.1. Elôzmények, publikációk . . . . . . . . . . . . . . . . 2

1.2. A dolgozat felépítése és tartalma . . . . . . . . . . . . . . . 4

2. Húrrezgések megfigyelési problémái általánosított függvények köré$\begin{array}{ll}\text { ben } & 6\end{array}$

2.1. Egy egyszerú megfigyelési probléma a Klein-Gordon egyenletre . . . . . 6

2.2. Egy általános megfigyelési probléma változó együtthatós egyenletre . . 15

2.3. Példák . . . . . . . . . . . . . . . . . . . . . . . . 23

2.3.1. Rögzített balvégpontú és szabad jobbvégpontú rezgő húr . . . . 23

2.3.2. Rezgố húr szabad végpontokkal . . . . . . . . . . . . . . 25

2.3.3. Rezgő húr Sturm-Liouville peremfeltételekkel . . . . . . . . . . . 27

2.3.4. Megfigyelési eredmények tetszóleges megfigyelési időpontok esetén 28

3. A Duhamel-elv egy változata

4. Klasszikus kitüzésû megfigyelési problémák 46

4.1. A végtelen rezgố húr problémája külső erőhatás mellett . . . . . . . . . 46

4.2. Egy speciális eset . . . . . . . . . . . . . . . . . . . . 48

4.3. Kiterjesztés félvégtelen húrra . . . . . . . . . . . . . . . . . . . . 52

4.3.1. A rögzített végpont esete . . . . . . . . . . . . . . . . . . 52

4.3.2. A szabad végpont esete . . . . . . . . . . . . . . . . 55

4.4. Az általános megfigyelési feltételek esete . . . . . . . . . . . . . . 57

5. Összefoglalás $\quad 63$

$\begin{array}{ll}\text { 6. Summary } & 68\end{array}$

Köszönetnyilvánítás $\quad 73$

$\begin{array}{ll}\text { Irodalomjegyzék } & 74\end{array}$ 


\section{1. fejezet}

\section{Bevezetés}

\subsection{Elốzmények, publikációk}

A megfigyelési (avagy megfigyelhetôségi) problémák eredete az irányításelmélet témakörébe nyúlik vissza, ami kiterjedt irodalommal rendelkezik, lásd [1]-[11]. Az egyik leggyakoribb (és sikeresen megoldott) kontroll-probléma a következő: adott egy $T$ idôpont $(0<T<\infty)$, és elő van írva egy rendszer teljes állapota ebben a $T$ idôpontban:

$$
\left.u\right|_{t=T}=f_{1},\left.\quad u_{t}\right|_{t=T}=f_{2}
$$

ahol $\underline{u}$ egy másodrendú, hiperbolikus parciális differenciálegyenlet ismeretlen megoldása, $f_{1}$ és $f_{2}$ ismert függvények, és keresendók az $\left.u\right|_{t=0},\left.u_{t}\right|_{t=0}$ kezdeti adatok, ahonnan indulva a rendszer eléri az előírt $\left(f_{1}, f_{2}\right)$ állapotot a $t=T$ idôpillanatban.

Egy, a másodrendú, hiperbolikus típusú egyenletekre (a jelen értekezésben húrrezgés egyenletekre) kitúzött legegyszerúbb megfigyelhetôségi probléma a következô: megtalálni azon $\left.u\right|_{t=0},\left.u_{t}\right|_{t=0}$ kezdeti adatokat, ahonnan indulva valamely $t_{1}, t_{2}$ időpontokban előírt (avagy megfigyelt)

$$
\left.u\right|_{t=t_{1}}=f_{1},\left.\quad u\right|_{t=t_{2}}=f_{2}
$$

részleges állapotok előállnak.

Tehát a fentebb említett irányításelméletbeli kérdéshez képest a fő különbség, hogy nem egy késóbb idôpontbeli teljes állapotra, hanem több időpontbeli, de csak részleges állapotra van feltételünk. A megfigyelt részleges állapotokat megfigyelési feltételeknek, a hozzájuk kapcsolódó időpontokat megfigyelési időpontoknak fogjuk nevezni.

Elképzelhetô egy problémához kapcsolódóan számos megfigyelési idôpont is, de a jelen disszertáció során előkerülő problémákban mindig két megfigyelt részleges állapotról lesz szó, és az ehhez tartozó idôpontokat konzisztensen $t_{1}$-gyel és $t_{2}$-vel fogjuk jelölni. A szokásos feltételeket általánosítva tetszóleges előjelü $t_{1}, t_{2} \in \mathbb{R}$ megfigyelési 
időpontokat fogunk használni, és a tárgyalt húrrezgésegyenleteket is tetszőleges $t \in \mathbb{R}$ és tetszóleges $t_{0} \in \mathbb{R}$ kezdeti időpont esetén fogjuk vizsgálni.

$\mathrm{Az}$ értekezésben szereplő függvényeket gyakran argumentumukkal együtt adjuk meg. Pl. a kétváltozós

$$
u:\left\{\begin{array}{c}
(x, t) \rightarrow u(x, t) \\
{[0, l] \times \mathbb{R} \rightarrow \mathbb{R}}
\end{array} \in C^{2}([0, l] \times \mathbb{R})\right.
$$

függvényre - amennyiben az félreértést nem okoz $-u(x, t) \in C^{2}([0, l] \times \mathbb{R})$ formában is hivatkozunk ennek rövidsége és érthetősége miatt.

A disszertáció dr. Hegedûs Jenôvel közösen végzett kutatáson alapul ([14], [15], [17], [18]), melynek kezdete egészen e disszertáció szerzője [13] diplomamunkájáig nyúlik vissza.

A megfigyelési problémáknak nem túl széles a szakirodalma, az általunk vizsgált megfigyelési feladatokhoz talán a [12] munka áll legközelebb, melyben L. N. Znamenskaya a rezgő $[0, l]$ húrral kapcsolatosan négy alapvetô megfigyelhetôségi problémát vizsgált. Nevezetesen az

$$
u_{t t}(x, t)-a^{2} u_{x x}(x, t)=0, \quad(x, t) \in[0, l] \times[0, T]
$$

egyenlet azon megoldásait kereste homogén peremfeltételek mellett, melyek kielégítik a következô megfigyelési feltételek (azonos sorbeli feltételpárok) valamelyikét:

$$
\begin{aligned}
\left.u\right|_{t=t_{1}}=f_{1}, & \left.u\right|_{t=t_{2}}=f_{2}, \\
\left.u\right|_{t=t_{1}}=f_{1}, & \left.u_{t}\right|_{t=t_{2}}=f_{2}, \\
\left.u_{t}\right|_{t=t_{1}}=f_{1}, & \left.u\right|_{t=t_{2}}=f_{2}, \\
\left.u_{t}\right|_{t=t_{1}}=f_{1}, & \left.u_{t}\right|_{t=t_{2}}=f_{2} .
\end{aligned}
$$

A problémát sikerült megoldania, feltéve, hogy a megfigyelési idôpontok elég kicsik $\left(0<t_{1}<t_{2}<2 l / a\right)$, illetve ha az $\left.u\right|_{t=0}=\varphi,\left.u_{t}\right|_{t=0}=\psi$ kezdeti adatok ismertek egy $\left[h_{1}, h_{2}\right] \subset[0, l]$ részintervallumon.

Ezenkívül megemlítünk még néhány, az értekezés témájához hasonló munkát, amelyek rezgő rudakkal, lemezekkel és membránokkal kapcsolatos megfigyelési problémákat tárgyalnak. Ezek kronológiai sorrendben a következők: [19], [20] és részben [16]. Kiemeljük itt Ambroise Vest [16] dolgozatát, s annak fó eredményét, ami szerint (simaságvesztés mellett) azon $\left(t_{1}, t_{2}\right) \in \mathbb{R}^{2}$ párok halmazának a Lebesgue mértéke nulla, amelyekre nem áll fenn a $[0, l]$ húr standard rezgéseinek megfigyelhetôsége. 


\subsection{A dolgozat felépítése és tartalma}

A bevezetés után, a 2. Fejezetben általánosított függvények körében kitűzött megfigyelhetôségi problémákkal foglalkozunk. Előbb áttekintünk egy [14]-ben szereplő, az

$$
u_{t t}(x, t)=a^{2} u_{x x}(x, t)-c u(x, t), \quad(x, t) \in[0, l] \times \mathbb{R}, \quad 0<a, c \in \mathbb{R}
$$

Klein-Gordon egyenlettel kapcsolatos egyszerúbb problémát, majd rátérünk a [15]-ben megtalálható általános probléma tárgyalására. Ekkor a vizsgált egyenlet

$$
u_{t t}=\left(p(x) u_{x}\right)_{x}-q(x) u \equiv L u, \quad(x, t) \in[0, l] \times \mathbb{R}, \quad 0<p, q \in C^{\infty}([0, l])
$$

alakú, a peremfeltételek pedig az ismeretlen $u$ függvénynek, és annak $u_{x}$ deriváltjának az $x=0$ és $x=l$ végpontbeli értékének tetszóleges lineáris kombinációját tartalmazzák. A fố megszorításaink a sajátfrekvenciák aszimptotikus viselkedésére vonatkoznak, illetve egy diofantoszi feltételt jelentenek a megfigyelési idôpontokra vonatkozóan. Ezután áttekintünk három konkrét alkalmazást az előbbi eredmény illusztrálására.

A 3. Fejezet a végtelen húrra vonatkozó Duhamel-elv egy új változatát tartalmazza, ahol megmutatjuk, hogy a

$$
\begin{gathered}
v_{t t}(x, t)-a^{2} v_{x x}(x, t)=f(x, t), \quad(x, t) \in \mathbb{R}^{2}, \\
v(x, 0)=\varphi(x) \equiv 0, \quad v_{t}(x, 0)=\psi(x) \equiv 0
\end{gathered}
$$

kezdeti érték problémának $C^{2}$-beli megoldhatóságához az $f(x, t)$ erőfüggvényre tett szokásos, folytonos differenciálhatósági feltétel helyett elegendô azt megkövetelnünk, hogy $f$ folytonos, differenciálható a $t$ irány szerint, és az $f_{t}$ iránymenti derivált is folytonos. Ezen eredmények a [17] dolgozatban találhatóak meg.

A 4. Fejezetben végtelen húrok rezgéseire folytonosan differenciálható függvények körében kitûzött megfigyelhetôségi problémákkal foglalkozunk, zömében külső erô hatása mellett. Az élesebb megfigyelhetőségi tételek érdekében az előző fejezetben megkövetelt simaságot tesszük fel az $f$ erôfüggvényrôl, és mind $u$-tól, mind $u_{t}$-tôl függó megfigyelési feltételeket vizsgálunk a két $t=t_{1}, t_{2}$ megfigyelési időpontban. Előbb áttekintünk egy egyszerúbb esetet, amikor a megfigyelési feltételünkben bizonyos együtthatók nulla értéket vesznek fel, majd tükrözések módszerének segítségével állításunkat megfogalmazzuk félvégtelen húrokra is. Végül az általános esettel folytatjuk. A fejezet eredményei a [17] és [18] cikkekben találhatóak meg.

Kutatásunk során sikerült eredményeket elérni a téglalap, illetve kör alakú membránok rezgéseire vonatkozó megfigyelési feladatok kapcsán is, de csak az $f_{1}, f_{2}$ megfi- 
gyelési adatok speciális osztályai esetén, így ezek az értekezésben nem szerepelnek.

A disszertáció végén az eredményeinknek mind a magyar, mind az angol nyelvû összefoglalóját megadjuk. 


\section{2. fejezet}

\section{Húrrezgések megfigyelési problémái általánosított függvények körében}

\subsection{Egy egyszerü megfigyelési probléma a Klein-Gordon egyenletre}

Ebben az alfejezetben azt a viszonylag egyszerü megfigyelési problémát tárgyaljuk, amikor mindkét megfigyelt részleges állapot a húr pozíciója. Az itt használt metódus késôbb jó alapot szolgáltat a következő alfejezetbeli, általánosabb megfigyelési probléma vizsgálatához.

Tekintsük az $l$ hosszúságú húr rezgését, melyet a következő, Klein-Gordon egyenlet ír le:

$$
u_{t t}(x, t)=a^{2} u_{x x}(x, t)-c u(x, t), \quad(x, t) \in[0, l] \times \mathbb{R}, \quad 0<a, c \in \mathbb{R} .
$$

Itt $u(x, t)$ jelenti a rezgô húr $x$ koordinátájú pontjának transzverzális kitérését a $t$ idốpontban, továbbá a rezgés során jelen van egy, a kitéréssel arányos, azzal ellentétes irányú visszahúzó erô.

A húr rögzített végú, melyet a következő elsőfajú, homogén peremfeltételekkel fejezünk ki :

$$
u(0, t)=0, \quad u(l, t)=0, \quad t \in \mathbb{R} .
$$

A húr kezdeti helyzetét, illetve kezdeti sebességét pedig a következő függvényekkel adjuk meg:

$$
u(x, 0)=\varphi(x), \quad u_{t}(x, 0)=\psi(x), \quad 0 \leq x \leq l .
$$


A (2.1)-(2.3) probléma megoldását összehasonlítva ugyanezen probléma $c=0$ esetbeli megoldásával adódik (lásd [13]), hogy amennyiben

$$
\varphi \in C^{2}[0, l], \quad \psi \in C^{1}[0, l]
$$

adottak, és

$$
\varphi(0)=\varphi(l)=\varphi^{\prime \prime}(0)=\varphi^{\prime \prime}(l)=\psi(0)=\psi(l)=0
$$

akkor a (2.1)-(2.3) vegyes feladatnak pontosan egy klasszikus megoldása létezik, azaz található egyetlen olyan $u \in C^{2}([0, l] \times \mathbb{R})$ függvény, ami kielégíti (2.1)-(2.3)-at. A megoldás egyértelmûsége a [13]-ban bebizonyított energiabecslésból adódik. Az $u$ függvényt a Fourier módszer segítségével a következô alakban lehet előállítani:

$$
u(x, t)=\sum_{n=1}^{\infty}\left[\alpha_{n} \cos \left(t \omega_{n}\right)+\beta_{n} \sin \left(t \omega_{n}\right)\right] \sin \left(\frac{n \pi}{l} x\right), \quad(x, t) \in[0, l] \times \mathbb{R}
$$

ahol

$$
\begin{gathered}
\omega_{n}=\sqrt{\left(\frac{n \pi}{l} a\right)^{2}+c}, \quad n \in \mathbb{N}, \\
\varphi(x)=\sum_{n=1}^{\infty} \alpha_{n} \sin \left(\frac{n \pi}{l} x\right) \Rightarrow \alpha_{n}=\frac{2}{l} \int_{0}^{l} \varphi(x) \sin \left(\frac{n \pi}{l} x\right) d x, \quad n \in \mathbb{N}, \\
\psi(x)=\sum_{n=1}^{\infty} \omega_{n} \beta_{n} \sin \left(\frac{n \pi}{l} x\right) \Rightarrow \beta_{n}=\frac{1}{\omega_{n}} \frac{2}{l} \int_{0}^{l} \psi(x) \sin \left(\frac{n \pi}{l} x\right) d x, \quad n \in \mathbb{N} .
\end{gathered}
$$

Jelen értekezésben a (2.1)-(2.3) problémát, illetve a vele kapcsolatos megfigyelési problémákat általánosított függvények körében fogjuk vizsgálni.

Tetszőleges $s$ valós számra a $\sin \frac{n \pi}{l} x, n=1,2, \ldots$, függvények által kifeszített $D$ altéren tekintsük a következô euklideszi normát:

$$
\left\|\sum_{n=1}^{\infty} c_{n} \sin \left(\frac{n \pi}{l} x\right)\right\|_{s}:=\left(\sum_{n=1}^{\infty} n^{2 s}\left|c_{n}\right|^{2}\right)^{\frac{1}{2}} .
$$

Ha teljessé tesszük a $D$ teret erre a normára nézve, akkor egy Hilbert teret kapunk, melyet $D^{s}$-sel jelölünk. Könnyen ellenôrizhetô, hogy $s \geq 0$ esetén $D^{s}$ zárt altere a 
$H^{s}(0, l)$ Szoboljev térnek, azaz

$$
D^{s}=\left\{u \in H^{s}(0, l): u^{(2 i)}(0)=u^{(2 i)}(l)=0, i=0,1, \ldots,[(s-1) / 2]\right\} .
$$

Amennyiben azonosítjuk $D^{0}=L^{2}(0, l)$-et a duálisával, akkor azt kapjuk, hogy a $D^{-s}$ tér a $D^{s}$ tér duálisa. A [3] monográfia 1.3. és 2.2. fejezeteinek eredményei szerint tetszốleges $s$ valós számra $(\varphi, \psi) \in D^{s+1} \times D^{s}$ esetén a (2.1)-(2.3) vegyes feladatnak létezik pontosan egy $u$ megoldása, mely

$$
u \in C\left(D^{s+1}, \mathbb{R}\right) \cap C^{1}\left(D^{s}, \mathbb{R}\right) \cap C^{2}\left(D^{s-1}, \mathbb{R}\right)
$$

simaságú, továbbá érvényes a (2.5)-beli Fourier soros előállítás a (2.7) és (2.8)-beli $\alpha_{n}$ és $\beta_{n}$ együtthatókkal. Innentól kezdve ebben az alfejezetben $\varphi, \psi, f_{1}, f_{2}$ és $u$ függvények Fourier sorát a $D^{s}(0, l)$ terekben értjük. A $D^{s}$ terek tulajdonságairól a [4] könyvben található további információ.

Vizsgálatainkat a Klein-Gordon egyenlettel kapcsolatos négy olyan megfigyelési problémával kezdtük, amikor a $\varphi, \psi$ kezdeti függvények ismeretlenek, ellenben $f_{1}$ és $f_{2}$ adottak és olyan $u$ általánosított függvényeket keresünk, amelyekre a (2.10)-(2.13) megfigyelési feltételek valamelyike teljesül:

$$
\begin{array}{ll}
u\left(x, t_{1}\right)=f_{1}(x), \quad u\left(x, t_{2}\right)=f_{2}(x), & 0 \leq x \leq l, \\
u_{t}\left(x, t_{1}\right)=f_{1}(x), \quad u\left(x, t_{2}\right)=f_{2}(x), & 0 \leq x \leq l, \\
u\left(x, t_{1}\right)=f_{1}(x), \quad u_{t}\left(x, t_{2}\right)=f_{2}(x), & 0 \leq x \leq l, \\
u_{t}\left(x, t_{1}\right)=f_{1}(x), \quad u_{t}\left(x, t_{2}\right)=f_{2}(x), & 0 \leq x \leq l,
\end{array}
$$

ahol $u$ a (2.1)-(2.3) probléma megoldása. Tehát a $-\infty<t_{1}<t_{2}<\infty$ idôpontokban ismert a rezgố húr részleges állapota, melyet az $f_{1}$ és $f_{2}$ függvények fejeznek ki, a feladat pedig megtalálni a $\varphi, \psi$ kezdeti függvényeket ezen $f_{1}$ és $f_{2}$ segítségével.

Állításaink formalizálva a következők:

2.1. Tétel. Tegyük fel, hogy

$$
f_{1} \in D^{s+2}, \quad f_{2} \in D^{s+2}, \quad \text { valamely } s \in \mathbb{R} \text { számra, és }
$$




$$
t_{2}-t_{1}=\frac{p}{q} \frac{2 l}{a}, \quad p, q \in \mathbb{N},
$$

ahol $p$ és q relatív prímek. Továbbá tegyük fel, hogy

$$
\sin \left(\left(t_{2}-t_{1}\right) \sqrt{\left(\frac{n \pi}{l} a\right)^{2}+c}\right) \neq 0, \quad \forall n \in \mathbb{N}
$$

Ekkor a (2.1)-(2.3) problémához kapcsolódó, (2.10) feltételú megfigyelési probléma egyértelmüen megoldható a $(\varphi, \psi) \in D^{s+1} \times D^{s}$ kezdeti függvényekre. A bizonyítás konstruktiv, a kezdeti függvények Fourier soros reprezentációja a bizonyításban megtalálható.

2.2. Tétel. Tegyük fel, hogy

$$
f_{1} \in D^{s+1}, \quad f_{2} \in D^{s+2}, \quad \text { valamely } s \in \mathbb{R} \text { számra, }
$$

a (2.15) feltétel teljesül, továbbá

$$
\cos \left(\left(t_{2}-t_{1}\right) \sqrt{\left(\frac{n \pi}{l} a\right)^{2}+c}\right) \neq 0, \quad \forall n \in \mathbb{N}
$$

Ekkor a (2.1)-(2.3) problémához kapcsolódó, (2.11) feltételú megfigyelési probléma egyértelmúen megoldható a $(\varphi, \psi) \in D^{s+1} \times D^{s}$ kezdeti függvényekre.

2.3. Tétel. Tegyük fel, hogy

$$
f_{1} \in D^{s+2}, \quad f_{2} \in D^{s+1}, \quad \text { valamely } s \in \mathbb{R} \text { számra, }
$$

és a (2.15), (2.17) feltételek fennállnak.

Ekkor a (2.1)-(2.3) problémához kapcsolódó, (2.12) feltételú megfigyelési probléma egyértelmúen megoldható $a(\varphi, \psi) \in D^{s+1} \times D^{s}$ kezdeti függvényekre.

2.4. Tétel. Tegyük fel, hogy

$$
f_{1} \in D^{s+1}, \quad f_{2} \in D^{s+1}, \quad \text { valamely } s \in \mathbb{R} \text { számra, }
$$

és a (2.15), (2.16) feltételek teljesülnek.

Ekkor a (2.1)-(2.3) problémához kapcsolódó, (2.13) feltételú megfigyelési probléma egyértelmúen megoldható $a(\varphi, \psi) \in D^{s+1} \times D^{s}$ kezdeti függvényekre.

Jelen alfejezetben csak a 2.1. Tételt bizonyítjuk (tehát azt a megfigyelési problémát oldjuk meg, amikor a $t_{1}, t_{2}$ időpontokban a rezgő húr helyzetét figyeljük meg, és csak azt), de a másik három megfigyelési probléma (amikor a $t_{1}$ és $t_{2}$ idôpontokban a 
pozíció-sebesség, sebesség-pozíció vagy sebesség-sebesség ismert) tárgyalása is hasonló módon történik. Ezen eredmények bizonyításai [14]-ben megtalálhatóak, emellett a következô alfejezetbeli általánosabb tétel speciális eseteként is megkaphatóak, így a 2.2-2.4. Tételek bizonyításától itt eltekintünk,

Az 2.1. Tétel bizonyításához elôször is belátjuk a következô lemmát.

2.5. Lemma. Amennyiben a (2.15) feltétel teljesül, akkor létezik $N \in \mathbb{N}$ határszám és egy $m \in \mathbb{R}$ rögzített pozitív egész úgy, hogy

$$
\frac{1}{\left|\sin \left(\omega_{n}\left(t_{2}-t_{1}\right)\right)\right|}<\frac{n}{m}, \quad \forall n>N \text { esetén } .
$$

Bizonyítás. Elôször az egyenlőtlenség bal oldalának nevezôjén végzünk elemi átalakításokat:

$$
=\sin \left(\left(t_{2}-t_{1}\right) \frac{n \pi}{l} a+\left(t_{2}-t_{1}\right) \frac{\omega_{n}^{2}-\left(\frac{n \pi}{l} a\right)^{2}}{\omega_{n}+\frac{n \pi}{l} a}\right)=\sin \left(\left(t_{2}-t_{1}\right) \frac{n \pi}{l} a+\left(t_{2}-t_{1}\right) \frac{c}{\omega_{n}+\frac{n \pi}{l} a}\right) .
$$

A (2.15) feltételból következik, hogy

$$
\left(t_{2}-t_{1}\right) \frac{n \pi}{l} a=\frac{p}{q} 2 n \pi
$$

és ez legfeljebb $q$ darab különbözó értéket vehet fel $(\bmod 2 \pi)$, ahogy $n$-et változtatjuk.

Legyen

$$
z_{n}:=\left(t_{2}-t_{1}\right) \frac{n \pi}{l} a \quad \text { és } \quad d_{1}:=\min _{n, \sin z_{n} \neq 0}\left\{\left|\sin \left(z_{n}\right)\right|\right\} .
$$

Az abszolút érték képzés miatt létezik egy $d_{2}$ valós szám úgy, hogy

$$
\sin \left(d_{2}\right)=d_{1}, \quad 0<d_{2} \leq \frac{\pi}{2}
$$

Mivel $\omega_{n}$ értéke $n$ nagyságrendú, ezért könnyư látni, hogy

$$
\left(t_{2}-t_{1}\right) \frac{c}{\omega_{n}+\frac{n \pi}{l} a}=O\left(\frac{1}{n}\right) \quad \text { ha } n \rightarrow \infty .
$$

Ezért léteznek $N \in \mathbb{N}, m \in \mathbb{R}^{+}$konstansok úgy, hogy

$$
\frac{\pi m}{2 n}<\left|\left(t_{2}-t_{1}\right) \frac{c}{\omega_{n}+\frac{n \pi}{l} a}\right|<\frac{d_{2}}{2} \text { és } \frac{m}{n}<\sin \left(\frac{d_{2}}{2}\right), \quad \forall n>N .
$$


Tehát egyrészt, ha $\sin \left(\left(t_{2}-t_{1}\right) \frac{n \pi}{l} a\right) \neq 0$, akkor (2.19) következtében

$$
\left|\sin \left(\left(t_{2}-t_{1}\right) \frac{n \pi}{l} a+\left(t_{2}-t_{1}\right) \frac{c}{\omega_{n}+\frac{n \pi}{l} a}\right)\right|>\left|\sin \left(d_{2}-\frac{d_{2}}{2}\right)\right|=\sin \left(\frac{d_{2}}{2}\right)>\frac{m}{n},
$$

amint $n>N$.

Másrészt, ha $\sin \left(\left(t_{2}-t_{1}\right) \frac{n \pi}{l} a\right)=0$, akkor a (2.19) és a közismert

$$
|\sin t|>\frac{2}{\pi}|t|, \quad \text { ha } 0<|t|<\frac{\pi}{2}
$$

egyenlőtlenségek miatt azt kapjuk, hogy

$$
\begin{gathered}
\left|\sin \left(\left(t_{2}-t_{1}\right) \frac{n \pi}{l} a+\left(t_{2}-t_{1}\right) \frac{c}{\omega_{n}+\frac{n \pi}{l} a}\right)\right|=\left|\sin \left(\left(t_{2}-t_{1}\right) \frac{c}{\omega_{n}+\frac{n \pi}{l} a}\right)\right|> \\
>\frac{2}{\pi}\left|\left(t_{2}-t_{1}\right) \frac{c}{\omega_{n}+\frac{n \pi}{l} a}\right|>\frac{m}{n}, \quad \forall n>N \text { esetén. }
\end{gathered}
$$

Egy közös egyenlőtlenségbe írva az elóbbi két esetet pedig megkapjuk, hogy

$$
\left|\sin \left(\left(t_{2}-t_{1}\right) \frac{n \pi}{l} a+\left(t_{2}-t_{1}\right) \frac{c}{\omega_{n}+\frac{n \pi}{l} a}\right)\right|>\frac{m}{n}, \quad \forall n>N \text {-re, }
$$

és ez az amit a lemma állított.

A 2.1. Tétel bizonyítása. Mivel a (2.1)-(2.3) probléma bármely u megoldása felírható a (2.5) alakban valamilyen $\alpha_{n}, \beta_{n} ; n \in \mathbb{N}$ együtthatókkal, ezért a megfigyelési probléma visszavezethető ezen együtthatók olyan alkalmas megválasztására, melyekkel (2.10) fennáll.

Ehhez először helyettesítsük be a $t_{1}, t_{2}$ időpontokat a (2.5) elóállításba, majd követeljük meg a (2.10)-ben szereplő két feltétel teljesülését. Így a következô szükséges feltétételeket kapjuk az $\alpha_{n}, \beta_{n}$ együtthatókra:

$$
f_{1}(x)=u\left(x, t_{1}\right)=\sum_{n=1}^{\infty}\left[\alpha_{n} \cos \left(\omega_{n} t_{1}\right)+\beta_{n} \sin \left(\omega_{n} t_{1}\right)\right] \sin \left(\frac{n \pi}{l} x\right), \quad x \in[0, l],
$$

$$
f_{2}(x)=u\left(x, t_{2}\right)=\sum_{n=1}^{\infty}\left[\alpha_{n} \cos \left(\omega_{n} t_{2}\right)+\beta_{n} \sin \left(\omega_{n} t_{2}\right)\right] \sin \left(\frac{n \pi}{l} x\right), \quad x \in[0, l],
$$

ahol $\omega_{n}$ a (2.6)-ban megadott kifejezést jelöli.

A (2.14) feltétel biztosítja, hogy az $f_{1}(x), f_{2}(x)$ függvények egyértelmúen szinuszos 
Fourier sorba fejthetőek, amiket a (2.20), (2.21) egyenletekkel összevetve a következő szükséges feltételekhez jutunk $\alpha_{n}$-re és $\beta_{n}$-re:

$$
\begin{array}{ll}
\alpha_{n} \cos \left(\omega_{n} t_{1}\right)+\beta_{n} \sin \left(\omega_{n} t_{1}\right) & =\frac{2}{l} \int_{0}^{l} f_{1}(x) \sin \left(\frac{n \pi}{l} x\right) d x, \quad n \in \mathbb{N}, \\
\alpha_{n} \cos \left(\omega_{n} t_{2}\right)+\beta_{n} \sin \left(\omega_{n} t_{2}\right) & =\frac{2}{l} \int_{0}^{l} f_{2}(x) \sin \left(\frac{n \pi}{l} x\right) d x, \quad n \in \mathbb{N} .
\end{array}
$$

A (2.16) feltétel miatt ez a (2.22) egyenletrendszer egyértelműen megoldható az ismeretlen $\alpha_{n}, \beta_{n}$ együtthatókra, bármely $n \in \mathbb{N}$ esetén:

$$
\begin{aligned}
\alpha_{n} & =\frac{\sin \left(\omega_{n} t_{2}\right) \frac{2}{l} \int_{0}^{l} f_{1}(x) \sin \left(\frac{n \pi}{l} x\right) d x-\sin \left(\omega_{n} t_{1}\right) \frac{2}{l} \int_{0}^{l} f_{2}(x) \sin \left(\frac{n \pi}{l} x\right) d x}{\sin \left(\omega_{n}\left(t_{2}-t_{1}\right)\right)}, \\
\beta_{n}= & \frac{-\cos \left(\omega_{n} t_{2}\right) \frac{2}{l} \int_{0}^{l} f_{1}(x) \sin \left(\frac{n \pi}{l} x\right) d x+\cos \left(\omega_{n} t_{1}\right) \frac{2}{l} \int_{0}^{l} f_{2}(x) \sin \left(\frac{n \pi}{l} x\right) d x}{\sin \left(\omega_{n}\left(t_{2}-t_{1}\right)\right)} .
\end{aligned}
$$

Ez alapján pedig a keresett ismeretlen $\varphi, \psi$ függvényeket egyértelmúen fel tudjuk írni a (2.7), illetve a (2.8) alakban. Ezután már csak azt kell megmutatni, hogy az ezekkel az együtthatókkal felírt $\varphi$ és $\psi$ függvények rendre a $D^{s+1}$, illetve a $D^{s}$ osztályba tartoznak, azaz be kell látnunk, hogy a következô egyenlőtlenség fennáll:

$$
\max \left\{\|\varphi\|_{s+1}^{2},\|\psi\|_{s}^{2}\right\}<\infty
$$

Az átláthatóság kedvéért bevezetjük a következô jelöléseket:

$$
\begin{aligned}
& D_{n}:=\frac{2}{l} \int_{0}^{l} f_{1}(x) \sin \left(\frac{n \pi}{l} x\right) d x, \\
& E_{n}:=\frac{2}{l} \int_{0}^{l} f_{2}(x) \sin \left(\frac{n \pi}{l} x\right) d x .
\end{aligned}
$$

Mivel $\left(f_{1}, f_{2}\right) \in D^{s+2} \times D^{s+2}$, így tudjuk, hogy az $f_{1}$ és $f_{2}$ függvények $D^{s+2}$ normája véges, azaz

$$
\sum_{n=1}^{\infty} n^{2 s+4} \max \left\{\left|D_{n}\right|^{2},\left|E_{n}\right|^{2}\right\}<\infty .
$$

Behelyettesítve $E_{n}$-et és $D_{n}$-et (2.23)-ba, illetve használva a 2.5. Lemmát, a következő 
becsléseket kapjuk az $\alpha_{n}, \beta_{n}$ együtthatókra, minden $n>N$-re:

$$
\begin{gathered}
\left|\alpha_{n}\right|=\left|\frac{\sin \left(\omega_{n} t_{2}\right) D_{n}-\sin \left(\omega_{n} t_{1}\right) E_{n}}{\sin \left(\omega_{n}\left(t_{2}-t_{1}\right)\right)}\right|<\left|\frac{n}{m} D_{n}\right|+\left|\frac{n}{m} E_{n}\right|, \\
\left|\beta_{n}\right|=\left|\frac{-\cos \left(\omega_{n} t_{2}\right) D_{n}+\cos \left(\omega_{n} t_{1}\right) E_{n}}{\sin \left(\omega_{n}\left(t_{2}-t_{1}\right)\right)}\right|<\left|\frac{n}{m} D_{n}\right|+\left|\frac{n}{m} E_{n}\right| .
\end{gathered}
$$

Ezen becslések alapján tehát létezik olyan $c_{1}>0$ konstans, hogy

$$
\max \left\{\left|\alpha_{n}\right|,\left|\beta_{n}\right|\right\}<c_{1} n \max \left\{\left|D_{n}\right|,\left|E_{n}\right|\right\}, \quad n \in \mathbb{N} .
$$

Mivel $\omega_{n}$ (lásd (2.6)) $n$ nagyságrendú, ezért létezik olyan $M \geq 1$ szám, hogy $\omega_{n}<$ $<M n, \forall n \in \mathbb{N}$-re, így a (2.25) és (2.26) egyenlőtlenségekból, illetve a $\|\cdot\|_{s}$ norma definíciójából megkapjuk a kívánt (2.24) egyenlőtlenséget:

$$
\begin{gathered}
\max \left\{\|\varphi\|_{s+1}^{2},\|\psi\|_{s}^{2}\right\}=\max \left\{\sum_{n=1}^{\infty} n^{2 s+2}\left|\alpha_{n}\right|^{2}, \sum_{n=1}^{\infty} n^{2 s}\left|\omega_{n} \beta_{n}\right|^{2}\right\} \leq \\
\leq \sum_{n=1}^{\infty} M^{2} n^{2 s+2} \max \left\{\left|\alpha_{n}\right|^{2},\left|\beta_{n}\right|^{2}\right\}<c_{1}^{2} M^{2} \sum_{n=1}^{\infty} n^{2 s+4} \max \left\{\left|D_{n}\right|^{2},\left|E_{n}\right|^{2}\right\}<\infty .
\end{gathered}
$$

2.6. Megjegyzés. A 2.1. Tételbeli, általánosított függvények körében tett állításunkból a klasszikus esetre is tudunk következtetni. Ugyanis ha

$$
\begin{gathered}
u\left(x, t_{1}\right)=f_{1}(x) \in C^{4}[0, l], \quad u\left(x, t_{2}\right)=f_{2}(x) \in C^{4}[0, l] \\
\left.f_{1}\right|_{0, l}=\left.f_{2}\right|_{0, l}=\left.f_{1}^{\prime \prime}\right|_{0, l}=\left.f_{2}^{\prime \prime}\right|_{0, l}=0
\end{gathered}
$$

akkor $f_{1}, f_{2} \in D^{4}$, és alkalmazva a 2.1. Tételt (feltéve, hogy (2.15) és (2.16) fennállnak) azt kapjuk, hogy a megfigyelési probléma egyértelmúen megoldható, és erre az $u$ megoldásra

$$
u(x, 0)=\varphi(x) \in D^{3} \subset C^{2}, \quad u_{t}(x, 0)=\psi(x) \in D^{2} \subset C^{1},
$$

azaz $u$ a klasszikus megoldás.

2.7. Megjegyzés. A (2.18) átalakítás segítségével a (2.16) feltétel a következô alakot veszi fel:

$$
\sin \left(\left(t_{2}-t_{1}\right) \omega_{n}\right)=\sin \left(\left(t_{2}-t_{1}\right) \frac{n \pi}{l} a+\left(t_{2}-t_{1}\right) \frac{c}{\sqrt{\left(\frac{n \pi}{l} a\right)^{2}+c}+\frac{n \pi}{l} a}\right) \neq 0
$$


minden $n \in \mathbb{N}$-re. Megvizsgálva a 2.5. Lemmát azt láthatjuk, hogy az az itt szereplő kifejezés abszolút értékének reciprokára ad becslést. Emiatt elég nagy $n$ számokra $(n>$ $>N)$ a (2.15) feltétel teljesülése maga után vonja, hogy a fentebbi feltétel is teljesül. Így pedig, ha szeretnénk, a (2.16) feltétel helyett tehetünk könnyen ellenốrizhetô (de nem szükséges) kikötést. Például

$$
\left(t_{2}-t_{1}\right) \frac{c}{\sqrt{\left(\frac{\pi}{l} a\right)^{2}+c}+\frac{\pi}{l} a}<\frac{\pi}{q}
$$

egy ilyen feltétel. Ez a következóképpen látható be. A (2.27)-beli szinusz függvény argumentumának elsố tagja vagy $0(\bmod 2 \pi)$, vagy legalább $\pi / q$ távolságra van a szinusz zéróhelyeitől. A (2.27)-beli szinusz függvény argumentumának második tagja pedig pozitív csökkenő függvénye $n$-nek, így ha feltesszük, hogy a második tag már $n=$ $=1$ esetén is kisebb, mint $\pi / q$ - ami éppen (2.28) - akkor (2.27) teljesülni fog minden $n \geq 1$ egész számra.

Mindazonáltal ebból az egyszerúbb (2.28) feltételból látható, hogy amennyiben a vizsgált (2.1) egyenletben a $c$ paraméter elég kicsi, vagy az a paraméter elég nagy, akkor (2.27) mindig fennáll.

Amennyiben a 2.1. Tétellel analóg állítást szeretnénk megfogalmazni a standard rezgó húrral kapcsolatban ( $c=0$ eset), akkor azt tapasztaljuk, hogy a (2.16) feltétel szerint a $\left(t_{2}-t_{1}\right) a / l$ kifejezés irracionális kell legyen, különben a keresett $\varphi$, $\psi$ függvények csak speciális $f_{1}, f_{2}$ megfigyelési adatok esetén lennének meghatározhatóak. Amennyiben $\left(t_{2}-t_{1}\right) a / l$ irracionális, akkor - a 2.1. Tétel bizonyításához hasonló módon - elő tudjuk állítani a keresett $\varphi, \psi$ kezdeti függvények (2.7), (2.8) alakú Fourier soros reprezentációját, de ekkor nem áll rendelkezésünkre a (2.26) becslés, és így ezen sorok sem klasszikus, sem $D^{s}$-beli konvergenciáját, illetve a velük előállított függvények kellő simaságát sem tudjuk így garantálni.

Ambroise Vest késóbb részletesen vizsgálta a [16] munkájában ezt az esetet, melyre vonatkozóan a következő tételt sikerült bebizonyítania:

2.8. Tétel (A. Vest, [16], Theorem 3.3., p. 5). Legyen $(\varphi, \psi) \in D^{s} \times D^{s-1}$ és $\left(f_{1}, f_{2}\right) \in$ $\in D^{r} \times D^{r}$. Ekkor c $=0$ esetén a (2.1), (2.2), (2.3), (2.10) megfigyelési problémával kapcsolatban:

- ha $r-s<1$, akkor semmilyen $\left(t_{1}, t_{2}\right)$ megfigyelési idöpontok esetén nem oldható meg a megfigyelési probléma.

- ha $r-s=1$, akkor azon $\left(t_{1}, t_{2}\right)$ párok halmaza, melyekre a megfigyelési probléma megoldható 0 Lebesgue mértékú és teljes Hausdorff dimenziójú $\mathbb{R}^{2}$-ben. 
- ha $r-s>1$, akkor a megfigyelési probléma egy nulla Lebesgue mértékú halmazt leszámítva minden $\left(t_{1}, t_{2}\right)$ pár esetén megoldató.

\subsection{Egy általános megfigyelési probléma változó együtt- hatós egyenletre}

Ebben az alfejezetben a 2.1. Alfejezet eredményeit általánosítjuk. Mint azt majd látni fogjuk, mind a vizsgált egyenlet, mind a lehetséges peremfeltételek, mind a megfigyelt részleges állapotok terén a korábbiaknál általánosabb megfigyelési problémákat is sikerül megoldanunk.

Továbbra is általánosított függvények körében dolgozunk. A 2.1. Alfejezethez hasonlóan most is a $D^{s}(S), s \in \mathbb{R}$ tereket használjuk.

Legyen adva egy $\left\{X_{n}(x)\right\}_{n=0}^{\infty}$ teljes ortonormált bázis az $L_{2}(S)$ térben. Tetszóleges valós $s$ szám esetén tekintsük az $X_{n}(x)$ függvények által kifeszített lineáris $D$ alteret, ahol $n \in \mathbb{N}_{0}=\mathbb{N} \bigcup\{0\}, x \in \bar{S}$. Tekintsük ezen a téren a következő euklideszi normát:

$$
\left\|\sum_{n=0}^{\infty} c_{n} X_{n}(x)\right\|_{s}:=\left(\sum_{n=0}^{\infty} n^{2 s}\left|c_{n}\right|^{2}\right)^{\frac{1}{2}} .
$$

Teljessé téve a $D$ teret erre a normára nézve egy Hilbert teret kapunk, melyet $D^{s}$-sel jelölünk. A húrrezgésekkel kapcsolatban mi az $S=(0, l)$ intervallumot, bázisnak pedig majd a (2.34)-beli $\left\{X_{n}(x)\right\}_{n=0}^{\infty}$ rendszert fogjuk használni,

Az alábbi, (2.29)-(2.31) vegyes feladattal kapcsolatos megfigyelési problémát fogjuk vizsgálni.

$$
\begin{gathered}
u_{t t}=\left(p(x) u_{x}\right)_{x}-q(x) u \equiv L u, \quad(x, t) \in[0, l] \times \mathbb{R}, \quad 0<p, q \in C^{\infty}([0, l]), \\
\left.u\right|_{t=0}=\varphi(x),\left.\quad u_{t}\right|_{t=0}=\psi(x),
\end{gathered}
$$

ahol $\mathcal{U}_{1}, \mathcal{U}_{2}$ független, önadjungált, lineáris kifejezések, $u, \varphi, \psi$ függvények a $D^{s}$ általánosított függvénytérból származnak, és ennek megfelelően (2.31) és (a nemsokára következô) (2.32) feltételeket is az általánosított függvények körében értjük. 
Az általánosság megszorítása nélkül feltehetjük, hogy az

$$
y=y(x), \quad L \sim\left(p(x) y^{\prime}\right)^{\prime}-q(x) y
$$

közönséges differenciálegyenlethez tartozó

$$
L y=0, \quad \mathcal{U}_{i}[y]=0, \quad i=1,2,
$$

homogén peremérték feladatnak csak triviális megoldása van. Az L közönséges differenciáloperátor önadjungált, így az $\mathcal{L} \sim\left(L, \mathcal{U}_{1}, \mathcal{U}_{2}\right)$ operátor is önadjungált.

A célunk az előző alfejezetbelihez hasonló eredményt bizonyítani az ehhez a vegyes feladathoz kapcsolódó megfigyelési problémára. Ehhez pedig a következő megfigyelési feltételeket tesszük, melyek a $t_{1}$ és $t_{2}$ idôpontokban a pozíció és sebesség valamely ismert, tetszóleges lineáris kombinációját tartalmazzák:

$$
\begin{array}{ll}
\left.A_{1} u\right|_{t=t_{1}}+\left.B_{1} u_{t}\right|_{t=t_{1}}=f_{1}, & \left|A_{1}\right|+\left|B_{1}\right|>0, \\
\left.A_{2} u\right|_{t=t_{2}}+\left.B_{2} u_{t}\right|_{t=t_{2}}=f_{2}, & \left|A_{2}\right|+\left|B_{2}\right|>0,
\end{array}
$$

ahol $A_{1}, A_{2}, B_{1}, B_{2}, f_{1}$ és $f_{2}$ adottak. Vegyük észre, hogy amennyiben a megfelelő együtthatók nullák, akkor visszakaphatjuk a (2.10)-(2.13) megfigyelési feltételek valamelyikét.

Állításunk megfogalmazásához tegyük fel, hogy bármely $s \in \mathbb{R}$ és bármely $(\varphi, \psi) \in$ $\in D^{s+1}(0, l) \times D^{s}(0, l)$ esetén a $(2.29)-(2.31)$ vegyes feladat rendelkezik az alábbi jó tulajdonságokkal:

$$
\exists ! u \text { megoldás és } u \in C\left(D^{s+1}, \mathbb{R}\right) \cap C^{1}\left(D^{s}, \mathbb{R}\right) \cap C^{2}\left(D^{s-1}, \mathbb{R}\right),
$$

és $u$ felírható a következô alakban

$$
\begin{gathered}
u(x, t)=\sum_{n=0}^{\infty}\left[\alpha_{n} \cos \left(\omega_{n} t\right)+\beta_{n} \sin \left(\omega_{n} t\right)\right] X_{n}(x), \quad(x, t) \in[0, l] \times \mathbb{R}, \text { ahol } \\
L X_{n}=-\omega_{n}^{2} X_{n}, \quad \mathcal{U}_{i} X_{n}=0, \quad i=1,2 .
\end{gathered}
$$

2.9. Megjegyzés. Azon problémák halmaza melyek kielégítik $\left(L, \mathcal{U}_{1}, \mathcal{U}_{2}\right)$-re tett megszorításainkat és a (2.33), (2.34) feltételeinket nem üres. Tartalmazza például az előző alfejezetben részletesen megvizsgált problémát, a 2.3.1., 2.3.2. és 2.3.3. Szakaszbeli példákat, továbbá például a (2.29)-(2.31) problémát az

$$
\begin{array}{cc}
\mathcal{U}_{1}: & a_{11} y^{\prime}(0)+a_{12} y^{\prime}(l)=0, \\
\mathcal{U}_{2}: & a_{21} y(0)+a_{22} y(l)=0,
\end{array}
$$


peremfeltétel mellett, ha $a_{12} a_{22} p(0)=a_{11} a_{21} p(l)$. Ez utóbbi egyenlőség szükséges és elegendő feltétele annak, hogy ekkor az $\mathcal{L} \sim\left(L, \mathcal{U}_{1}, \mathcal{U}_{2}\right)$ operátor önadjungált legyen.

A későbbiekben szükségünk lesz a következô lemmára bizonyos becslésekhez.

2.10. Lemma. Legyen az $r_{n}$ számsorozat olyan, hogy $0<M / n<\left|r_{n}\right| \rightarrow 0$ valamely $M$ pozitiv valós konstanssal és legyen $x_{0}>0$ racionális szám. Ekkor bármely rögzített $d \in \mathbb{R}$ számra létezik egy $N$ határszám, hogy

$$
\left|\sin \left(n \pi x_{0}+d+r_{n}\right)\right|>\frac{M}{2 n}, \quad \forall n>N-r e .
$$

Bizonyítás. Mivel $x_{0}$ racionális, így felírható $x_{0}=p / q ; p, q \in \mathbb{N}$ alakban. Ez azt is jelenti, hogy $\sin \left(n \pi x_{0}+d\right)$ legfeljebb $q$ darab különbözô értéket vehet fel. Legyen $\mathbb{N}_{1}$ és $\mathbb{N}_{2}$ diszjunkt felbontása a természetes számoknak úgy, hogy

$$
\begin{gathered}
\mathbb{N}_{1} \bigcup \mathbb{N}_{2}=\mathbb{N}, \\
\sin \left(n \pi x_{0}+d\right)=0 \text { ha } n \in \mathbb{N}_{1}, \\
\sin \left(n \pi x_{0}+d\right) \neq 0 \text { ha } n \in \mathbb{N}_{2} .
\end{gathered}
$$

A lemma állításában szereplő egyenlőtlenséget ezen két számhalmazra külön-külön látjuk be.

Egyrészt, amennyiben $n \in \mathbb{N}_{1}$, akkor

$$
\left|\sin \left(n \pi x_{0}+d+r_{n}\right)\right|=\left|\sin \left(r_{n}\right)\right|>\frac{1}{2}\left|r_{n}\right|>\frac{M}{2 n}
$$

bármely elég nagy $\mathbb{N}_{1}$-beli $n$ természetes számra, mivel feltételeink szerint $r_{n} \rightarrow 0$ amint $n \rightarrow \infty$.

Másrészt, ha $n \in \mathbb{N}_{2}$, az azt jelenti, hogy létezik egy $d_{1}>0$ konstans úgy, hogy $\left|\sin \left(n \pi x_{0}+d\right)\right|>d_{1}$ minden $n \in \mathbb{N}_{2}$ esetén. A szinusz függvény egyenletes folytonosságából következik, hogy a

$$
\left|\sin \left(n \pi x_{0}+d+r_{n}\right)\right|>\frac{d_{1}}{2}>\frac{M}{2 n}
$$

egyenlőtlenség minden elég nagy $n \in \mathbb{N}_{2}$ számra teljesül.

Egyesítve a két esetet megkapjuk a 2.10. Lemma állítását.

Ennyi előkészület után fogalmazzuk meg tételünket a megfigyelési problémánk megoldhatóságáról. 
2.11. Tétel. Legyen

$$
f_{1} \in D^{s+2}, f_{2} \in D^{s+2}, \quad s \in \mathbb{R},
$$

és tegyük fel, hogy léteznek $0<A \in \mathbb{Q}, B \in \mathbb{R}, 0<M_{1} \in \mathbb{R}$ konstansok és $C_{n} \in \mathbb{R} \backslash\{0\}$ sorozat úgy, hogy

$$
\begin{gathered}
\omega_{n}\left(t_{2}-t_{1}\right)+\gamma_{n}-\delta_{n}=n \pi A+B+C_{n}, \\
0<\frac{M_{1}}{n}<\left|C_{n}\right|, \forall n \in \mathbb{N} \quad \text { és } \quad C_{n} \rightarrow 0 \text { amint } n \rightarrow \infty,
\end{gathered}
$$

és

$$
\sin \left(\omega_{n}\left(t_{2}-t_{1}\right)+\gamma_{n}-\delta_{n}\right) \neq 0, \quad n \in \mathbb{N}_{0}
$$

$A z$ itt szerepló $\gamma_{n}, \delta_{n} \in[0,2 \pi)$ szögek az alábbi egyenletek által egyértelmúen meghatározottak:

$$
\begin{aligned}
& \sin \gamma_{n}=\frac{A_{1}}{\sqrt{A_{1}^{2}+B_{1}^{2} \omega_{n}^{2}}}, \quad \cos \gamma_{n}=\frac{B_{1} \omega_{n}}{\sqrt{A_{1}^{2}+B_{1}^{2} \omega_{n}^{2}}}, \\
& \sin \delta_{n}=\frac{A_{2}}{\sqrt{A_{2}^{2}+B_{2}^{2} \omega_{n}^{2}}}, \quad \cos \delta_{n}=\frac{B_{2} \omega_{n}}{\sqrt{A_{2}^{2}+B_{2}^{2} \omega_{n}^{2}}} .
\end{aligned}
$$

Amennyiben a (2.29)-(2.31) vegyes feladat megoldása kielégíti a (2.33), (2.34) feltételeket és (2.35), (2.36), (2.37) fennállnak, akkor a (2.29)-(2.31) problémával kapcsolatos megfigyelési problémának a (2.32) megfigyelési feltétel mellett létezik pontosan egy $(\varphi, \psi) \in D^{s+1} \times D^{s}$ megoldása.

2.12. Megjegyzés. A (2.36) feltétel alapján használhatjuk a 2.10. Lemmát a

$$
\sin \left(\omega_{n}\left(t_{2}-t_{1}\right)+\gamma_{n}-\delta_{n}\right)=\sin \left(n \pi A+B+C_{n}\right),
$$

kifejezés becslésére, ami egyben azt is jelenti, hogy $\sin \left(\omega_{n}\left(t_{2}-t_{1}\right)+\gamma_{n}-\delta_{n}\right) \neq 0$ automatikusan teljesül minden elég nagy $n$ számra (amikor $n>N$ ). Tehát ha a gyakorlatban érdekel minket, hogy (2.37) fennáll -e, akkor nem kell végtelen sok egyenlőséget ellenőrizni.

A 2.11. Tétel bizonyítása. Nyilvánvaló, hogy a kezdeti függvények egyértelmúen Fourier sorba fejthetőek az $\left\{X_{n}\right\}_{n=0}^{\infty}$ rendszer szerint valamilyen - egyelőre ismeretlen - 
$\alpha_{n}, \omega_{n} \beta_{n} ; n \in \mathbb{N}_{0}$ együtthatókkal:

$$
\varphi(x)=u(x, 0)=\sum_{n=0}^{\infty} \alpha_{n} X_{n}(x)
$$

$$
\psi(x)=u_{t}(x, 0)=\sum_{n=0}^{\infty} \omega_{n} \beta_{n} X_{n}(x)
$$

Mivel a (2.29)-(2.31) vegyes feladat $u$ megoldása előállítható (2.34) alakban, ezért a megfigyelési probléma visszavezethető $\alpha_{n}$ és $\beta_{n}$ olyan alkalmas megválasztásaira, hogy a velük előállított $u$ függvényre (2.32) teljesüljön. Ehhez helyettesítsük be a (2.34) reprezentációba a $t_{1}, t_{2}$ megfigyelési időpontokat, és az így kapott kifejezéseket vessük össze a (2.32) megfigyelési feltételekkel. Ezáltal a következô szükséges feltételeket nyerjük $\alpha_{n}$-re és $\beta_{n}$-re:

$$
=\sum_{n=0}^{\infty}\left[\alpha_{n}\left(A_{1} \cos \left(\omega_{n} t_{1}\right)-B_{1} \omega_{n} \sin \left(\omega_{n} t_{1}\right)\right)+\beta_{n}\left(A_{1} \sin \left(\omega_{n} t_{1}\right)+B_{1} \omega_{n} \cos \left(\omega_{n} t_{1}\right)\right)\right] X_{n}(x),
$$

$$
f_{2}(x)=A_{2} u\left(x, t_{2}\right)+B_{2} u_{t}\left(x, t_{2}\right)=
$$

$$
=\sum_{n=0}^{\infty}\left[\alpha_{n}\left(A_{2} \cos \left(\omega_{n} t_{2}\right)-B_{2} \omega_{n} \sin \left(\omega_{n} t_{2}\right)\right)+\beta_{n}\left(A_{2} \sin \left(\omega_{n} t_{2}\right)+B_{2} \omega_{n} \cos \left(\omega_{n} t_{2}\right)\right)\right] X_{n}(x) .
$$

Mivel $f_{1} \in D^{s+2}$ és $f_{2} \in D^{s+2}$, ezért $f_{1}$ és $f_{2}$ Fourier sorainak az $\left\{X_{n}\right\}_{n=0}^{\infty}$ szerinti sorfejtésének együtthatói egyértelmúen meghatározottak. Ezen Fourier sorokat összevetve (2.40)-nel és (2.41)-gyel a következő feltételeket kapjuk az $\alpha_{n}, \beta_{n}$ együtthatókra:

$$
\begin{aligned}
& \alpha_{n}\left(A_{1} \cos \left(\omega_{n} t_{1}\right)-B_{1} \omega_{n} \sin \left(\omega_{n} t_{1}\right)\right)+\beta_{n}\left(A_{1} \sin \left(\omega_{n} t_{1}\right)+B_{1} \omega_{n} \cos \left(\omega_{n} t_{1}\right)\right)=D_{n}, \\
& \alpha_{n}\left(A_{2} \cos \left(\omega_{n} t_{2}\right)-B_{2} \omega_{n} \sin \left(\omega_{n} t_{2}\right)\right)+\beta_{n}\left(A_{2} \sin \left(\omega_{n} t_{2}\right)+B_{2} \omega_{n} \cos \left(\omega_{n} t_{2}\right)\right)=E_{n},
\end{aligned}
$$

ahol

$$
D_{n}=\int_{0}^{l} f_{1}(x) X_{n}(x) d x \quad \text { és } \quad E_{n}=\int_{0}^{l} f_{2}(x) X_{n}(x) d x .
$$

Behelyettesítve $\gamma_{n}$-et és $\delta_{n}$-et a (2.42) egyenletrendszerekbe - trigonometrikus azonos- 
ságok használata után - azt kapjuk, hogy

$$
\begin{aligned}
& -\alpha_{n} \sin \left(\omega_{n} t_{1}-\gamma_{n}\right)+\beta_{n} \cos \left(\omega_{n} t_{1}-\gamma_{n}\right)=\frac{D_{n}}{\sqrt{A_{1}^{2}+B_{1}^{2} \omega_{n}^{2}}} \\
& -\alpha_{n} \sin \left(\omega_{n} t_{2}-\delta_{n}\right)+\beta_{n} \cos \left(\omega_{n} t_{2}-\delta_{n}\right)=\frac{E_{n}}{\sqrt{A_{2}^{2}+B_{2}^{2} \omega_{n}^{2}}}
\end{aligned}
$$

Ezek a lineáris egyenletrendszerek egyértelmúen megoldhatóak az ismeretlen $\alpha_{n}, \beta_{n}$ együtthatókra, mivel a (2.37) feltétellel feltettük, hogy a determinánsa semmilyen $n$ esetén sem nulla:

$$
\begin{aligned}
\alpha_{n} & =\frac{\sqrt{A_{2}^{2}+B_{2}^{2} \omega_{n}^{2}} \cos \left(\omega_{n} t_{2}-\delta_{n}\right) D_{n}-\sqrt{A_{1}^{2}+B_{1}^{2} \omega_{n}^{2}} \cos \left(\omega_{n} t_{1}-\gamma_{n}\right) E_{n}}{\sqrt{A_{1}^{2}+B_{1}^{2} \omega_{n}^{2}} \sqrt{A_{2}^{2}+B_{2}^{2} \omega_{n}^{2}} \sin \left(\omega_{n}\left(t_{2}-t_{1}\right)+\gamma_{n}-\delta_{n}\right)}, \\
\beta_{n} & =\frac{\sqrt{A_{2}^{2}+B_{2}^{2} \omega_{n}^{2}} \sin \left(\omega_{n} t_{2}-\delta_{n}\right) D_{n}-\sqrt{A_{1}^{2}+B_{1}^{2} \omega_{n}^{2}} \sin \left(\omega_{n} t_{1}-\gamma_{n}\right) E_{n}}{\sqrt{A_{1}^{2}+B_{1}^{2} \omega_{n}^{2}} \sqrt{A_{2}^{2}+B_{2}^{2} \omega_{n}^{2}} \sin \left(\omega_{n}\left(t_{2}-t_{1}\right)+\gamma_{n}-\delta_{n}\right)} .
\end{aligned}
$$

Ezzel egyértelmúen meghatároztuk a keresett $\varphi$ és $\psi$ kezdeti függvényeket a (2.38) és (2.39) alakban. Már csak azt kell megmutatni, hogy $\varphi, \psi$ rendre a $D^{s+1}, D^{s}$ osztályból valóak, azaz hogy a következó egyenlótlenség fennáll:

$$
\max \left\{\|\varphi\|_{s+1},\|\psi\|_{s}\right\}=\max \left\{\sum_{n=0}^{\infty} n^{2 s+2}\left|\alpha_{n}\right|^{2}, \sum_{n=0}^{\infty} n^{2 s}\left|\omega_{n} \beta_{n}\right|^{2}\right\}<\infty
$$

Vegyük észre, hogy a (2.36) feltétel magában foglalja, hogy $\left|\omega_{n}\right|=O(n)$, tehát használva a 2.10. Lemmát és a (2.43) előállítást azt kapjuk, hogy létezik egy $M$ konstans, amire

$$
\begin{array}{ll}
\left|\alpha_{n}\right| \leq\left|M \frac{n}{1+B_{1} n} D_{n}\right|+\left|M \frac{n}{1+B_{2} n} E_{n}\right|, \quad & \forall n>N, \\
\left|\beta_{n}\right| \leq\left|M \frac{n}{1+B_{1} n} D_{n}\right|+\left|M \frac{n}{1+B_{2} n} E_{n}\right|, \quad \forall n>N,
\end{array}
$$

ez pedig azt jelenti, hogy

$$
\max \left\{\left|\alpha_{n}\right|,\left|\beta_{n}\right|\right\}<c_{1} n \max \left\{\left|D_{n}\right|,\left|E_{n}\right|\right\}, \quad n \in \mathbb{N}_{0},
$$

valamilyen $c_{1}$ konstanssal.

Világos, hogy ez a (2.45)-ös becslés (és így egyben a (2.35) feltétel) javítható, amennyiben $B_{1} \neq 0$ vagy $B_{2} \neq 0$ (lásd 2.15. Megjegyzés késóbb).

Használva a (2.45) egyenlőtlenséget arra jutunk, hogy 


$$
\begin{gathered}
\max \left\{\sum_{n=0}^{\infty} n^{2 s+2}\left|\alpha_{n}\right|^{2}, \sum_{n=0}^{\infty} n^{2 s}\left|\omega_{n} \beta_{n}\right|^{2}\right\} \leq \sum_{n=0}^{\infty} C^{2} n^{2 s+2} \max \left\{\left|\alpha_{n}\right|^{2},\left|\beta_{n}\right|^{2}\right\}< \\
<c_{1}^{2} C^{2} \sum_{n=0}^{\infty} n^{2 s+4} \max \left\{\left|D_{n}\right|^{2},\left|E_{n}\right|^{2}\right\},
\end{gathered}
$$

ahol

$$
\sum_{n=0}^{\infty} n^{2 s+4} \max \left\{\left|D_{n}\right|^{2},\left|E_{n}\right|^{2}\right\} \leq\left\|f_{1}\right\|_{s+2}^{2}+\left\|f_{2}\right\|_{s+2}^{2}<\infty
$$

az $s+2$ norma definíciója szerint, hiszen feltettük, hogy $\left(f_{1}, f_{2}\right) \in D^{s+2} \times D^{s+2}$.

2.13. Megjegyzés. A fentebbi vizsgálatok és becslések azt mutatják, hogy az az $\mathcal{A}$ operátor, ami a részleges, $t_{1}, t_{2}$ idôpontokban megfigyelt $\left(f_{1}, f_{2}\right)$ állapotokat hozzárendeli a $(\varphi, \psi)$ párhoz, egy folytonos (korlátos) lineáris operátor $D^{s+2} \times D^{s+2}$-ról $D^{s+1} \times$ $\times D^{s}$-be.

A (2.11). Tétel bizonyítását újra megvizsgálva, a (2.42) egyenletrendszerből kiindulva arra jutunk, hogy

$$
\begin{aligned}
& \alpha_{n} \sin \left(\omega_{n}\left(t_{2}-t_{1}\right)+\gamma_{n}-\delta_{n}\right)=\frac{D_{n} \cos \left(\omega_{n} t_{2}-\delta_{n}\right)}{v_{n}}-\frac{E_{n} \cos \left(\omega_{n} t_{1}-\gamma_{n}\right)}{w_{n}}, \\
& \beta_{n} \sin \left(\omega_{n}\left(t_{2}-t_{1}\right)+\gamma_{n}-\delta_{n}\right)=\frac{D_{n} \sin \left(\omega_{n} t_{2}-\delta_{n}\right)}{v_{n}}-\frac{E_{n} \sin \left(\omega_{n} t_{1}-\gamma_{n}\right)}{w_{n}},
\end{aligned}
$$

ahol

$$
v_{n}=\sqrt{A_{1}^{2}+B_{1}^{2} \omega_{n}^{2}}, \quad w_{n}=\sqrt{A_{2}^{2}+B_{2}^{2} \omega_{n}^{2}},
$$

és evidens, hogy

$$
\begin{gathered}
v_{n}=\left|A_{1}\right| \text {, ha } B_{1}=0, \quad w_{n}=\left|A_{2}\right| \text {, ha } B_{2}=0, \\
v_{n}=O(n) \text {, ha } B_{1} \neq 0, \quad w_{n}=O(n) \text {, ha } B_{2} \neq 0, \quad n \rightarrow \infty .
\end{gathered}
$$

Az $\alpha_{n}, \beta_{n}$ Fourier együtthatók végtelenben való viselkedése alapján azt kapjuk, hogy

$$
\begin{aligned}
& \sum_{n=0}^{\infty}\left(n^{2 s+4}\left|\alpha_{n}\right|^{2}+n^{2 s+2}\left|\omega_{n} \beta_{n}\right|^{2}\right) \sin ^{2}\left(\omega_{n}\left(t_{2}-t_{1}\right)+\gamma_{n}-\delta_{n}\right) \leq \\
& \leq C \sum_{n=0}^{\infty}\left(n^{2 s+4}\left|D_{n}\right|^{2}+n^{2 s+4}\left|E_{n}\right|^{2}\right) \leq C\left(\left\|f_{1}\right\|_{s+2}^{2}+\left\|f_{2}\right\|_{s+2}^{2}\right),
\end{aligned}
$$

ami azt mutatja, hogy a $(\varphi, \psi)=\mathcal{A}\left(f_{1}, f_{2}\right)$ párra kissé erősebb simaság is érvényes. Ez pedig azt sugallja, hogy a 2.11. Tételbelinél kissé élesebb állítás is tehetô.

Ehhez vezessük be a $D_{0}^{s} \subset D^{s}$ altereket, ami azon $f \in D^{s}$ függvényeket tartalmazza, amiknek az $f_{n}$ Fourier együtthatói $n \in \mathbb{N}_{1}$ esetén (az $\mathbb{N}_{1}$ halmaz a vizsgált problémától 
függ, a definícióját lásd a 2.10. Lemmában) a következő tulajdonsággal rendelkezik:

$$
\sum_{n \in \mathbb{N}_{1}}\left|f_{n}\right|^{2}|n|^{2 s+2}<\infty
$$

Természetesen ez a definíció maga után vonja, hogy $D^{s+1} \subset D_{0}^{s}$.

2.14. Tétel. Amennyiben a 2.11. Tétel feltételei teljesülnek, továbbá $f_{1}, f_{2} \in D_{0}^{s+1}$ ( $D^{s+2}$ helyett), akkor a (2.29)-(2.31) problémához kapcsolódó megfigyelési problémának a (2.32) megfigyelési feltétel mellett pontosan egy $(\varphi, \psi) \in D^{s+1} \times D^{s}$ megoldása létezik.

Más szavakkal, az $\mathcal{A}: \mathcal{A}(f, g):=(\varphi, \psi)$ operátor, ami $D_{0}^{s+1} \times D_{0}^{s+1}$-ról képez $D^{s+1} \times D^{s}$-be, folytonos (korlátos) operátor.

Bizonyítás. Ugyanazokat a lépéseket tehetjük, amiket a 2.11. Tétel bizonyítása során. Csak azt kell a korábbiakon felül megmutatnunk, hogy (2.44) abban az esetben is fennáll, ha $\left(f_{1}, f_{2}\right) \in D_{0}^{s+1} \times D_{0}^{s+1}$. Valóban, hiszen ekkor a következô érvényes:

$$
\begin{gathered}
\max \left\{\sum_{n=0}^{\infty} n^{2 s+2}\left|\alpha_{n}\right|^{2}, \sum_{n=0}^{\infty} n^{2 s}\left|\omega_{n} \beta_{n}\right|^{2}\right\} \leq \sum_{n=0}^{\infty} C^{2} n^{2 s+2} \max \left\{\left|\alpha_{n}\right|^{2},\left|\beta_{n}\right|^{2}\right\}= \\
=\sum_{n \in \mathbb{N}_{1}} C^{2} n^{2 s+2} \max \left\{\left|\alpha_{n}\right|^{2},\left|\beta_{n}\right|^{2}\right\}+\sum_{n \in \mathbb{N}_{2}} C^{2} n^{2 s+2} \max \left\{\left|\alpha_{n}\right|^{2},\left|\beta_{n}\right|^{2}\right\} .
\end{gathered}
$$

Használva a (2.44) egyenlőtlenséget az elsô szummára azt kapjuk, hogy

$$
\sum_{n \in \mathbb{N}_{1}} C^{2} n^{2 s+2} \max \left\{\left|\alpha_{n}\right|^{2},\left|\beta_{n}\right|^{2}\right\} \leq c_{1}^{2} C^{2} \sum_{n \in \mathbb{N}_{1}} n^{2 s+4} \max \left\{\left|D_{n}\right|^{2},\left|E_{n}\right|^{2}\right\}
$$

ami a $D_{0}^{s+1}$ terek definíciója miatt véges.

Viszont $n \in \mathbb{N}_{2}$ esetén javíthatunk a (2.44) egyenlőtlenségen. Ugyanis ezen $n$ értékekre (amennyiben $n$ elég nagy) teljesül, hogy

$$
\sin \left(\omega_{n}\left(t_{2}-t_{1}\right)+\gamma_{n}-\delta_{n}\right)>\frac{d_{1}}{2}
$$

ahogy azt a 2.10. Lemma bizonyítása során láthattuk. Ebből pedig az következik, hogy

$$
\max \left\{\left|\alpha_{n}\right|,\left|\beta_{n}\right|\right\}<c_{2} \max \left\{\left|D_{n}\right|,\left|E_{n}\right|\right\}, \quad \forall n \in \mathbb{N}_{2} \text {-re }
$$

valamilyen alkalmas $c_{2}$ konstanssal. Tehát így azt kapjuk, hogy

$$
\sum_{n \in \mathbb{N}_{2}} C^{2} n^{2 s+2} \max \left\{\left|\alpha_{n}\right|^{2},\left|\beta_{n}\right|^{2}\right\} \leq c_{2}^{2} C^{2} \sum_{n \in \mathbb{N}_{2}} n^{2 s+2} \max \left\{\left|D_{n}\right|^{2},\left|E_{n}\right|^{2}\right\}<\infty
$$

köszönhetôen annak, hogy $D_{0}^{s+1} \subset D^{s+1}$. 
2.15. Megjegyzés. Ahogy korábban említettük, a (2.45)-ös egyenlőtlenség javítható, amennyiben $B_{1} \neq 0$ vagy $B_{2} \neq 0$. Pontosabban, amikor $B_{1} \neq 0$, akkor $f_{1} \in D^{s+1}$; míg ha $B_{2} \neq 0$ akkor $f_{2} \in D^{s+1}$ simaságot elegendő megkövetelni a (2.35) feltételben.

Abban a speciális esetben, ha mind $A_{1}, B_{1}$ valamelyike, mind $A_{2}, B_{2}$ valamelyike nulla, akkor a (2.32) megfigyelési feltétel a (2.10)-(2.13) feltételek egyikére vezet az $A_{1}, A_{2}, B_{1}, B_{2}$ együtthatók közül a megfelelőekkel való osztás után. Ebben az esetben $\gamma_{n} \equiv 0$ vagy $\gamma_{n} \equiv \pi / 2$; illetve $\delta_{n} \equiv 0$ vagy $\delta_{n} \equiv \pi / 2$, és a (2.36), (2.37) feltételek is ennek megfelelően egyszerüsödnek.

2.16. Megjegyzés. A 2.11. Tétel (2.36) feltételét a 2.10. Lemma segítségével arra használtuk, hogy rendelkezzünk a következô típusú becsléssel:

$$
\frac{1}{\left|\sin \left(\omega_{n}\left(t_{2}-t_{1}\right)+\gamma_{n}-\delta_{n}\right)\right|}<\frac{n}{c_{3}}, \quad c_{3} \in \mathbb{R}^{+}, \forall n>N
$$

Viszont a (2.36) feltétel nem szükséges, helyettesíthetjük például azzal a feltevéssel, hogy $D_{n}=E_{n}=0$ minden $n \in \mathcal{K}(\epsilon)$ esetén, ahol tetszólegesen kis rögzített $\epsilon>0$ számra $\mathcal{K}(\epsilon) \subset \mathbb{N}$ azon $n$ természetes számok gyújteménye, melyekre

$$
-\epsilon<\omega_{n}\left(t_{2}-t_{1}\right)+\gamma_{n}-\delta_{n}<\epsilon \bmod (\pi) .
$$

\subsection{Példák}

Ebben az alfejezetben a 2.11. Tétel alkalmazhatóságának illusztrálására megadunk három példát. Mint látni fogjuk, a (2.33), (2.34), (2.36) megkötéseink konkrét feladat esetén gyakran nem jelentenek megszorítást, mert adott kitǔzés esetén automatikusan telesülhetnek. Végül áttekintjük, hogy mi a helyzet abban az esetben, ha a (2.36), (2.37) feltételeink nem teljesülnek.

\subsubsection{Rögzített balvégpontú és szabad jobbvégpontú rezgő húr}

Tekintsük ismét a 2.1. Alfejezetben is vizsgált Klein-Gordon egyenletet, azaz azon rezgô húr egyenletét, amikor jelen van egy, a kitéréssel arányos, azzal ellentétes irányú rugalmas visszahúzó erő. Az e jelenséget leíró

$$
u_{t t}(x, t)=a^{2} u_{x x}(x, t)-c u(x, t), \quad(x, t) \in[0, l] \times \mathbb{R}, \quad 0<a, c \in \mathbb{R}
$$

egyenletet a

$$
u(x, 0)=\varphi(x), \quad u_{t}(x, 0)=\psi(x), \quad 0 \leq x \leq l
$$


kezdeti feltételekkel tekintjük. A szakasz címének megfelelő homogén peremfeltételeink pedig:

$$
u(0, t)=0, \quad u_{x}(l, t)=0, \quad t \in \mathbb{R} .
$$

Ahogy a 2.1. Alfejezet esetében, úgy most is [3] 1.3. és 2.2. fejezetei alapján tudjuk, hogy tetszóleges $s \in \mathbb{R}$ és $(\varphi, \psi) \in D^{s+1} \times D^{s}$ esetén a (2.46)-(2.48) vegyes feladat megoldása kielégíti a (2.33), (2.34) feltételeinket, és ha figyelembe vesszük, hogy $q(x) \equiv c>0$, akkor azt kapjuk, hogy

$$
X_{n}=\sqrt{\frac{2}{l}} \sin \left(\frac{\left(n+\frac{1}{2}\right) \pi}{l} x\right), \quad n \in \mathbb{N}_{0},
$$

és

$$
u(x, t)=\sum_{n=0}^{\infty}\left[\alpha_{n} \cos \left(\omega_{n} t\right)+\beta_{n} \sin \left(\omega_{n} t\right)\right] \sqrt{\frac{2}{l}} \sin \left(\frac{\left(n+\frac{1}{2}\right) \pi}{l} x\right), \quad(x, t) \in[0, l] \times \mathbb{R} .
$$

Itt az $\omega_{n}$ sajátfrekvencia

$$
\omega_{n}=\sqrt{\left(\frac{\left(n+\frac{1}{2}\right) \pi a}{l}\right)^{2}+c,} \quad n \in \mathbb{N}_{0}
$$

amit átalakítva azt kapjuk, hogy

$$
\begin{gathered}
\omega_{n}=\frac{\left(n+\frac{1}{2}\right) \pi a}{l}+\left(\omega_{n}-\frac{\left(n+\frac{1}{2}\right) \pi a}{l}\right)=\frac{\left(n+\frac{1}{2}\right) \pi a}{l}+\frac{\omega_{n}^{2}-\left(\frac{\left(n+\frac{1}{2}\right) \pi a}{l}\right)^{2}}{\omega_{n}+\frac{\left(n+\frac{1}{2}\right) \pi a}{l}}= \\
=n \frac{\pi a}{l}+\frac{\pi a}{2 l}+\frac{c}{\omega_{n}+\frac{\left(n+\frac{1}{2}\right) \pi a}{l}} .
\end{gathered}
$$

Tekintsük a (2.32) megfigyelési feltételt:

$$
\begin{aligned}
& \left.A_{1} u\right|_{t=t_{1}}+\left.B_{1} u_{t}\right|_{t=t_{1}}=f_{1}, \quad\left|A_{1}\right|+\left|B_{1}\right|>0, \\
& \left.A_{2} u\right|_{t=t_{2}}+\left.B_{2} u_{t}\right|_{t=t_{2}}=f_{2}, \quad\left|A_{2}\right|+\left|B_{2}\right|>0,
\end{aligned}
$$

és továbbá tegyük fel, hogy $A_{1} B_{1} \geq 0$ és $A_{2} B_{2} \leq 0$. Az általánosság megszorítása nélkül feltehetjük, hogy $A_{1}, B_{1}, B_{2} \geq 0$ és $A_{2} \leq 0$. Ezeket az együtthatókat behelyettesítve a $\gamma_{n}, \delta_{n}$ szögek definíciójába (lásd a 2.11. Tételt), ebból az következik, hogy $\sin \gamma_{n} \rightarrow 0^{+}$, $\gamma_{n} \rightarrow 0^{+}, \sin \delta_{n} \rightarrow 0^{-}, \delta_{n} \rightarrow 0^{-} ;$amint $n \rightarrow \infty$. Tehát létezik egy $N \in \mathbb{N}$ küszöbszám 
úgy, hogy bármely $n>N$ esetén,

$$
0 \leq \frac{2}{\pi} \gamma_{n} \leq \sin \gamma_{n} \leq \gamma_{n}, \quad \delta_{n} \leq \sin \delta_{n} \leq \frac{2}{\pi} \delta_{n} \leq 0
$$

Köszönhetően annak, hogy

$$
\sin \gamma_{n}=\frac{A_{1}}{\sqrt{A_{1}^{2}+B_{1}^{2} \omega_{n}^{2}}}, \quad \sin \delta_{n}=\frac{A_{2}}{\sqrt{A_{2}^{2}+B_{2}^{2} \omega_{n}^{2}}}, \quad \omega_{n}=O(n),
$$

létezik olyan $M \in \mathbb{R}^{+} \bigcup\{0\}$ konstans, amire

$$
0 \leq \frac{M}{n} \leq \gamma_{n} \rightarrow 0, \quad 0 \leq \frac{M}{n} \leq-\delta_{n} \rightarrow 0 .
$$

Tehát a (2.36) feltétel teljesül az

$$
A=\left(t_{2}-t_{1}\right) \frac{a}{l}, \quad B=\left(t_{2}-t_{1}\right) \frac{\pi a}{2 l}, \quad C_{n}=\left(t_{2}-t_{1}\right) \frac{c}{\omega_{n}+\frac{\left(n+\frac{1}{2}\right) \pi a}{l}}+\gamma_{n}-\delta_{n}
$$

tagokkal, feltéve, hogy $\left(t_{2}-t_{1}\right) \frac{a}{l} \in \mathbb{Q}$.

Következésképpen alkalmazhatjuk a 2.11. Tételt, így pedig a következó állítást nyerjük.

2.17. Tétel. Legyen

$$
f_{1} \in D^{s+2}, f_{2} \in D^{s+2}, \quad s \in \mathbb{R},
$$

és tegyük fel, hogy

$$
\sin \left(\left(t_{2}-t_{1}\right) \omega_{n}+\gamma_{n}-\delta_{n}\right) \neq 0, \quad n \in \mathbb{N}_{0}
$$

Ekkor a (2.46), (2.47), (2.48) vegyes feladathoz kapcsolódó megfigyelési probléma a (2.32) megfigyelési feltétel mellett egyértelmüen megoldható a $(\varphi, \psi) \in D^{s+1} \times D^{s}$ kezdeti függvényekre, feltéve, hogy a megfigyelési feltételben szerepló együtthatókra teljesül, hogy $A_{1} B_{1} \geq 0, A_{2} B_{2} \leq 0$, továbbá a $t_{1}$ és $t_{2}$ megfigyelési idópontok között eltelt idó l/a racionális többszöröse.

\subsubsection{Rezgô húr szabad végpontokkal}

Az elôző problémához képest változtassunk annyit, hogy most legyen a rezgő húr mindkét végpontja szabad, azaz a következô, Neumann típusú peremfeltételt használjuk:

$$
u_{x}(0, t)=0, \quad u_{x}(l, t)=0, \quad t \in \mathbb{R} .
$$


A [3] könyv 1.3. és 2.2. fejezetei szerint tetszóleges $s \in \mathbb{R}$ és $(\varphi, \psi) \in D^{s+1} \times D^{s}$ esetén a (2.46), (2.47), (2.49) vegyes feladat megoldása kielégíti a (2.33), (2.34) feltételeket, továbbá ebben a speciális esetben az $X_{n}$ bázis és a (2.34)-beli sorfejtés a következő alakokat veszik fel:

$$
\begin{gathered}
X_{0}=\sqrt{\frac{1}{l}} \quad \text { és } \quad X_{n}=\sqrt{\frac{2}{l}} \cos \left(\frac{n \pi}{l} x\right), \quad n \in \mathbb{N}, \\
u(x, t)=\sum_{n=0}^{\infty}\left[\alpha_{n} \cos \left(\omega_{n} t\right)+\beta_{n} \sin \left(\omega_{n} t\right)\right] X_{n}(x), \quad(x, t) \in[0, l] \times \mathbb{R} .
\end{gathered}
$$

Itt a sajátfrekvencia

$$
\omega_{n}=\sqrt{\left(\frac{n \pi a}{l}\right)^{2}+c}, \quad n \in \mathbb{N}_{0},
$$

ahonnan

$$
\omega_{n}=\frac{n \pi a}{l}+\left(\omega_{n}-\frac{n \pi a}{l}\right)=n \frac{\pi a}{l}+\frac{\omega_{n}^{2}-\left(\frac{n \pi a}{l}\right)^{2}}{\omega_{n}+\frac{n \pi a}{l}}=n \frac{\pi a}{l}+\frac{c}{\omega_{n}+\frac{n \pi a}{l}} .
$$

Amennyiben $A_{1} B_{1} \geq 0$ és $A_{2} B_{2} \leq 0$, akkor megismételve a 2.3.1 Szakaszban szereplő gondolatmenetet a $\gamma_{n}, \delta_{n}$ szögekre arra jutunk, hogy (2.36) teljesül a következőekkel:

$$
A=\left(t_{2}-t_{1}\right) \frac{a}{l}, \quad B=0, \quad C_{n}=\left(t_{2}-t_{1}\right) \frac{c}{\omega_{n}+\frac{n \pi a}{l}}+\gamma_{n}-\delta_{n}
$$

feltéve, hogy $\left(t_{2}-t_{1}\right) \frac{a}{l} \in \mathbb{Q}$.

Ezek alapján a következóképpen alkalmazhatjuk a 2.11. Tételt a szabad végpontokkal rendelkező rezgő húrra.

2.18. Tétel. Legyen

$$
f_{1} \in D^{s+2}, f_{2} \in D^{s+2}, \quad s \in \mathbb{R},
$$

és tegyük fel, hogy

$$
\sin \left(\left(t_{2}-t_{1}\right) \omega_{n}+\gamma_{n}-\delta_{n}\right) \neq 0, \quad n \in \mathbb{N}_{0}
$$

Ekkor a (2.46), (2.47), (2.49) vegyes feladattal kapcsolatos megfigyelési probléma a (2.32) megfigyelési feltétel mellett egyértelmüen megoldható a $(\varphi, \psi) \in D^{s+1} \times D^{s}$ kezdeti függvényekre, feltéve, hogy a (2.32) megfigyelési feltételben szereplö együtthatókra $A_{1} B_{1} \geq 0$ és $A_{2} B_{2} \leq 0$ teljesülnek, továbbá a $t_{1}$ és $t_{2}$ megfigyelési idópontok között eltelt idố $l / a$ racionális többszöröse. 


\subsubsection{Rezgô húr Sturm-Liouville peremfeltételekkel}

Most tekintsük a véges, $[0, l]$ rezgô húr problémáját, változó nagyságú, az $u(x, t)$ kitéréssel arányos, azzal ellentétes irányú visszahúzóerő esetén Sturm-Liouville peremfeltételek mellett. Ekkor az egyenlet:

$$
u_{t t}(x, t)=a^{2} u_{x x}(x, t)-c(x) u(x, t), \quad(x, t) \in[0, l] \times \mathbb{R}, 0<a \in \mathbb{R},
$$

ahol $0<c(x) \in C^{2}[0, l]$; a kezdeti feltételek:

$$
u(x, 0)=\varphi(x), \quad u_{t}(x, 0)=\psi(x), \quad 0 \leq x \leq l
$$

és a Sturm-Liouville peremfeltételek:

$$
\begin{array}{cc}
u(0, t) \cos \alpha+u_{x}(0, t) \sin \alpha=0, & \cot \alpha<0, \\
u(l, t) \cos \beta+u_{x}(l, t) \sin \beta=0, & \cot \beta>0 .
\end{array}
$$

A (2.52) peremfeltételen belül a $\cot \alpha$ és $\cot \beta$ értékek előjelére vonatkozó feltétel biztosítja az energiamegmaradást, ezzel pedig garantálja, hogy a (2.50)-(2.52) vegyes feladat a klasszikus esetben egyértelmúen megoldható. Továbbá ennek a feltételnek köszönhetôen (a lentebb bevezetett) $\gamma$ konstans szigorúan pozitív lesz.

Ismét [3] 1.3. és 2.2. fejezetei szerint tetszóleges $s \in \mathbb{R}$ és $(\varphi, \psi) \in D^{s+1} \times D^{s}$ esetén a (2.50)-(2.52) vegyes feladat megoldása kielégíti (2.33), (2.34) feltételeket. A (2.34)-beli $\left\{X_{n}\right\}, n \in \mathbb{N}_{0}$ ortonormált bázis a [21], 5-13. o. eredményei alapján:

$$
X_{n}(x)=\sqrt{\frac{2}{\pi}}\left[\cos \left(\frac{n \pi}{l} x\right)+\frac{\beta(x)}{n} \sin \left(\frac{n \pi}{l} x\right)\right]+O\left(\frac{1}{n^{2}}\right)
$$

ahol

$$
\beta(x)=-\gamma \frac{\pi}{l} x-\frac{l}{\pi} \cot \alpha+\frac{1}{2 a^{2}} \int_{0}^{x} \frac{l}{\pi} c(\tau) d \tau .
$$

A (2.34) sorfejtett alak most

$$
u(x, t)=\sum_{n=0}^{\infty}\left[\alpha_{n} \cos \left(\omega_{n} t\right)+\beta_{n} \sin \left(\omega_{n} t\right)\right] X_{n}(x), \quad(x, t) \in[0, l] \times \mathbb{R},
$$

ahol

$$
\omega_{n}=\frac{a \pi}{l}\left(n+\frac{\gamma}{n}+O\left(\frac{1}{n^{3}}\right)\right), \quad \gamma=\frac{l}{\pi^{2}}\left(-\cot \alpha+\cot \beta+\frac{1}{2 a^{2}} \int_{0}^{l} c(\tau) d \tau\right) .
$$


Elvégezve a múveletet, $\omega_{n}$ felírható az

$$
\omega_{n}=n \frac{\pi a}{l}+\left(\frac{\gamma a \pi}{n l}+O\left(\frac{1}{n^{3}}\right)\right)
$$

alakban. Amennyiben $A_{1} B_{1} \geq 0$ és $A_{2} B_{2} \leq 0$, akkor a $\gamma_{n}$ és $\delta_{n}$ szögekre alkalmazva a korábbi, 2.3.1 Szakaszbeli gondolatmenetünket azt kapjuk, hogy (2.36) teljesül a következőekkel :

$$
A=\left(t_{2}-t_{1}\right) \frac{a}{l}, \quad B=0, \quad C_{n}=\left(t_{2}-t_{1}\right) \frac{\gamma a \pi}{n l}+\gamma_{n}-\delta_{n}+O\left(\frac{1}{n^{3}}\right)
$$

feltéve, hogy $\left(t_{2}-t_{1}\right) \frac{a}{l} \in \mathbb{Q}$.

Ezek alapján alkalmazhatjuk a 2.11. Tételt a Sturm-Liouville rögzítésú rezgő húrra.

2.19. Tétel. Legyen

$$
f_{1} \in D^{s+2}, f_{2} \in D^{s+2}, \quad s \in \mathbb{R},
$$

és tegyük fel, hogy

$$
\sin \left(\left(t_{2}-t_{1}\right) \omega_{n}+\gamma_{n}-\delta_{n}\right) \neq 0, \quad n \in \mathbb{N}_{0}
$$

Ekkor a (2.50), (2.51), (2.52) vegyes feladathoz kapcsolódó megfigyelési probléma a (2.32) megfigyelési feltétel mellett egyértelmüen megoldható a $(\varphi, \psi) \in D^{s+1} \times D^{s}$ kezdeti függvényekre, feltéve, hogy a megfigyelési feltételben szereplô együtthatókra teljesül, hogy $A_{1} B_{1} \geq 0, A_{2} B_{2} \leq 0$, továbbá a $t_{1}$ és $t_{2}$ megfigyelési idópontok között eltelt idó l/a racionális többszöröse.

\subsubsection{Megfigyelési eredmények tetszôleges megfigyelési idôpon- tok esetén}

Vizsgáljuk meg mi a helyzet akkor, amikor a 2.11. Tételben kitúzött megfigyelési probléma kapcsán a (2.36), (2.37) feltételek teljesülését nem követeljük meg, azaz abban az esetben, amikor a rendszer részleges állapotának a megfigyeléséhez a $t_{1}, t_{2}$ megfigyelési idôpontokat a megszorításainktól mentesen, tetszôlegesen választjuk. Ekkor a korábbitól eltérô, alternatív módszerhez folyamodhatunk, melyhez vezessük be a következô jelöléseket:

$$
\begin{gathered}
h_{n}:=\omega_{n}\left(t_{2}-t_{1}\right)+\gamma_{n}-\delta_{n}, \quad n \in \mathbb{N}_{0} \\
d_{n}:=\rho\left(h_{n}, \mathbb{N}_{0} \pi\right), \quad n \in \mathbb{N}_{0}, \quad \mathbb{N}_{0} \pi:=\bigcup_{k=0}^{\infty}\{k \pi\},
\end{gathered}
$$


azaz $d_{n}$ jelölje a $h_{n}$ érték távolságát a szinuszfüggvény legközelebbi zéróhelyétól.

- Amennyiben $d_{n}>0$ minden $n \in \mathbb{N}_{0}$ esetén (tehát (2.37) teljesül, csak (2.36) nem), akkor a megfigyelési probléma (formálisan) egyértelmúen megoldható, hiszen az $\alpha_{n}, \beta_{n}$ együtthatók egyértelmúen meghatározhatók a (2.42) egyenletrendszerból minden $n \in \mathbb{N}_{0}$ számra és definiálják a $\varphi$, $\psi$ kezdeti függvényeket. Viszont az $\alpha_{n}, \beta_{n}$ együtthatók becsléséhez (és így ahhoz, hogy a $\varphi, \psi$ függvények rendre a $D^{s+1}, D^{s}$ osztályhoz tartozzanak) speciális eszközök szükségesek (például a 2.2. Alfejezetben diofantikusakat használtunk). Egy általános eredmény lehet, a következô: a

$$
\varphi(x) \sim \sum_{n=0}^{\infty} \alpha_{n} X_{n}(x), \quad \psi(x) \sim \sum_{n=0}^{\infty} \omega_{n} \beta_{n} X_{n}(x)
$$

formális sorok rendelkeznek a következő tulajdonságokkal:

$$
\sum_{n=0}^{\infty} \alpha_{n} d_{n} X_{n}(x) \in D^{s+1}, \quad \sum_{n=0}^{\infty} \omega_{n} \beta_{n} d_{n} X_{n}(x) \in D^{s}
$$

mi több, a (2.53) tulajdonság akkor is teljesüljön, ha a $d_{n}$ távolságot helyettesítjük a $\widetilde{d}_{n}$ számmal, ami

$$
\widetilde{d}_{n}=\left\{\begin{array}{cl}
1, & d_{n} \geq \delta>0, \\
b_{n}, & d_{n}<\delta,
\end{array} \quad n \in \mathbb{N}_{0},\right.
$$

tetszőlegesen kicsi rögzített $\delta$ és tetszőleges $\left|b_{n}\right| \leq d_{n}$ esetén.

- Amennyiben bizonyos természetes számokra $d_{n}$ értéke nulla, akkor jelölje $\mathbb{N}(0)$ az összes ilyen természetes szám halmazát. Ekkor minden $n \in \mathbb{N}(0)$ szám esetén a (2.42) lineáris rendszer pontosan akkor oldható meg az $\left(\alpha_{n}, \beta_{n}\right)$ párra, ha a megfigyelt $f_{1}, f_{2}$ függvények Fourier együtthatóira teljesül, hogy

$$
\frac{D_{n}}{E_{n}}=\frac{A_{1} \cos \left(\omega_{n} t_{1}\right)-B_{1} \omega_{n} \sin \left(\omega_{n} t_{1}\right)}{A_{2} \cos \left(\omega_{n} t_{2}\right)-B_{2} \omega_{n} \sin \left(\omega_{n} t_{2}\right)}=\left(\frac{A_{1} \sin \left(\omega_{n} t_{1}\right)+B_{1} \omega_{n} \cos \left(\omega_{n} t_{1}\right)}{A_{2} \sin \left(\omega_{n} t_{2}\right)+B_{2} \omega_{n} \cos \left(\omega_{n} t_{2}\right)}\right) .
$$

Viszont a megoldás még így sem egyértelmú ezen $\left(\alpha_{n}, \beta_{n}\right)$ párokra, és ennélfogva a segítségükkel konstruált $\varphi, \psi$ kezdeti függvényekre sem, továbbá a $\varphi, \psi$ függvényeknek a rendre $D^{s+1}, D^{s}$ terekhez történő tartozása sem garantált. 


\section{3. fejezet}

\section{A Duhamel-elv egy változata}

A továbbiakban véges rezgések helyett rátérünk a végtelen rezgô húr vizsgálatára, a klasszikus tárgyalásmódra támaszkodva. Lényeges különbség az eddigiekhez képest, hogy ekkor rendelkezésünkre áll a D'Alembert formula, mely a Duhamel-elvvel együtt megadja az inhomogén egyenletú rezgó húr problémájának megoldását a kezdeti adatok és az inhomogenitást jelentő tag függvényeként. Szeretnénk a megfigyelési problémák témaköréhez tartozó eredményeinket a lehetô legáltalánosabb (de még klasszikus) külső erő hatása melletti húrrezgés egyenletekre megfogalmazni (lásd a következő fejezetben), ezért bemutatjuk a Duhamel-elv egy új változatát a végtelen rezgố húr esetére.

3.1. Tétel. Amennyiben $f(x, t) \in C\left(\mathbb{R}^{2}\right)$ és az $f$ függvény $t$ irány szerinti $f_{t}$ deriváltja létezik, továbbá $f_{t} \in C\left(\mathbb{R}^{2}\right)$, akkor a következô, (3.1)-(3.3) kezdeti érték problémának pontosan egy megoldása van.

$$
\begin{gathered}
v(x, t) \in C^{2}\left(\mathbb{R}^{2}\right), \\
v_{t t}(x, t)-a^{2} v_{x x}(x, t)=f(x, t), \quad(x, t) \in \mathbb{R}^{2}, \\
\left.v\right|_{t=0}=\left.v_{t}\right|_{t=0} \equiv 0
\end{gathered}
$$

A $v$ megoldás egy reprezentációját a

$$
v(x, t)=\frac{1}{2 a} \int_{0}^{t}\left(\int_{x-a(t-\tau)}^{x+a(t-\tau)} f(\xi, \tau) d \xi\right) d \tau, \quad(x, t) \in \mathbb{R}^{2}
$$

úgynevezett Duhamel-integrál adja meg.

A szokásos kitűzés $f(x, t) \in C^{1}\left(\mathbb{R}^{2}\right)$ simasági feltételét élesíti ez a tétel. De mielőtt 
bebizonyítjuk a 3.1. Tételt, elóbb bemutatunk négy példát, amik jellemzik az inhomogén hullámegyenlet klasszikus megoldásai simasági tulajdonságainak változatosságát, valamint azt, hogy a (3.4) Duhamel-integrál a 3.1. Tétel feltételeinél gyengébb feltételek mellett is megadhatja a (3.1)-(3.3) probléma (klasszikus) megoldását speciális $f$ erőfüggvény esetén.

3.2. Példa. Az $n$ dimenziós hullámegyenlet esetén, amennyiben $f(\underline{x}, t)=g(t) \in$ $\in C^{k}(\mathbb{R})$, akkor a

$$
\begin{gathered}
v_{t t}-a^{2} \sum_{i=1}^{n} v_{x_{i} x_{i}}=g(t), \quad(\underline{x}, t) \in \mathbb{R}^{n} \times \mathbb{R}, \\
\left.v\right|_{t=0}=\left.v_{t}\right|_{t=0} \equiv 0
\end{gathered}
$$

probléma v klasszikus megoldása a következố alakú:

$$
v(\underline{x}, t)=\int_{0}^{t}\left(\int_{0}^{\tau} g(s) d s\right) d \tau=\int_{0}^{t} g(\tau)(t-\tau) d \tau, \quad(\underline{x}, t) \in \mathbb{R}^{n} \times \mathbb{R}
$$

és nyilvánvaló, hogy $v \in C^{k+2}\left(\mathbb{R}^{n} \times \mathbb{R}\right)$. Azaz a $v \in C^{2}\left(\mathbb{R}^{n} \times \mathbb{R}\right)$ simasághoz elegendô, ha a g erófüggvény folytonos.

Természetesen ez a példa nem általánosítja a 3.1. Tételt, hiszen speciális alakú jobb oldalt vettünk, mindazonáltal ez a példa is azt mutatja, hogy a 3.1. Tételbeli feltételeink nem szükségesek a megoldás $v \in C^{2}$ simaságának biztosításához.

3.3. Példa. Rezgő húr esetén ( $n=1$ az elôzố példában), amennyiben $f(x, t)=h(x) \in$ $\in C(\mathbb{R})$ alakú, akkor a

$$
\begin{gathered}
v(x, t) \in C^{2}\left(\mathbb{R}^{2}\right), \\
v_{t t}(x, t)-a^{2} v_{x x}(x, t)=h(x), \quad(x, t) \in \mathbb{R}^{2}, \\
\left.v\right|_{t=0}=\left.v_{t}\right|_{t=0} \equiv 0
\end{gathered}
$$

probléma $v$ megoldása a következóképpen irható fel:

$$
v(x, t)=\frac{1}{2 a}\left[-\frac{2}{a} \widehat{H}(x)+\frac{1}{a} \widehat{H}(x+a t)+\frac{1}{a} \widehat{H}(x-a t)\right],
$$

ahol

$$
\widehat{H}(x)=\int_{0}^{x} H(s) d s, \quad H(x)=\int_{0}^{x} h(s) d s .
$$


A (3.5)-beli $v$ függvényt a (3.4) Duhamel-integrállal definiáljuk:

$$
\begin{gathered}
v(x, t)=\frac{1}{2 a} \int_{0}^{t}\left(\int_{x-a(t-\tau)}^{x+a(t-\tau)} h(s) d s\right) d \tau=\frac{1}{2 a} \int_{0}^{t}[H(x+a(t-\tau))-H(x-a(t-\tau))] d \tau= \\
=\frac{1}{2 a}\left[-\left.\frac{1}{a} \widehat{H}(x+a(t-\tau))\right|_{\tau=0} ^{\tau=t}-\left.\frac{1}{a} \widehat{H}(x-a(t-\tau))\right|_{\tau=0} ^{\tau=t}\right] .
\end{gathered}
$$

A (3.5) formulából közvetlenül látható, hogy ez a $v(x, t)$ függvény valóban megoldása a (3.1)-(3.3) problémának, és hogy a szokásos $f(x, t)=h(x) \in C^{1}(\mathbb{R})$ megkötés nem szükséges a $v$ megoldás $C^{2}\left(\mathbb{R}^{2}\right)$-beliségének biztosításához.

3.4. Példa. Továbbra is a rezgố húrnál maradva, ha

$$
f(x, t)=h(x)+g(t), \quad(x, t) \in \mathbb{R}^{2}, \quad h, g \in C(\mathbb{R}),
$$

alakra bontható, akkor a

$$
\begin{gathered}
v_{t t}(x, t)-a^{2} v_{x x}(x, t)=h(x)+g(t), \quad(x, t) \in \mathbb{R}^{2}, \\
\left.v\right|_{t=0}=\left.v_{t}\right|_{t=0}=0,
\end{gathered}
$$

probléma klasszikus $C^{2}$ megoldása $v=v_{1}+v_{2} \in C^{2}$, ahol a $v_{1}$ és $v_{2}$ függvények rendre a 3.2. ( $n=1$ esetben) és 3.3. Példa megoldásai.

Ezen 3.4. Példa eredménye élesebb mint a 3.1. Tételé a (3.6) speciális alakú jobboldal esetén.

3.5. Példa. Az általunk elózetesen megvizsgáltak közül ez van legközelebb a 3.1. Tételbeli helyzethez. Legyen $f(x, t)=h(x) g(t), h \in C(\mathbb{R}), g \in C^{1}(\mathbb{R})$. Ekkor a

$$
\begin{aligned}
v_{t t}(x, t)-a^{2} v_{x x}(x, t) & =h(x) g(t), \quad(x, t) \in \mathbb{R}^{2}, \\
\left.v\right|_{t=0} & =\left.v_{t}\right|_{t=0} \equiv 0
\end{aligned}
$$

probléma $v$ klasszikus megoldása a következô:

$$
v(x, t)=\frac{1}{2 a} \int_{0}^{t} g(\tau)[H(x+a(t-\tau))-H(x-a(t-\tau))] d \tau,
$$

ahol $v \in C^{2}\left(\mathbb{R}^{2}\right)$. Itt is (mint fentebb a 3.3. Példában) $H(x)=\int_{0}^{x} h(s) d s$. 
A (3.7)-beli $v$ függvényt szintén a (3.4) Duhamel-integrállal definiáljuk:

$$
\begin{gathered}
v(x, t)=\frac{1}{2 a} \int_{0}^{t}\left(\int_{x-a(t-\tau)}^{x+a(t-\tau)} h(s) g(\tau) d s\right) d \tau= \\
=\frac{1}{2 a} \int_{0}^{t} g(\tau)[H(x+a(t-\tau))-H(x-a(t-\tau))] d \tau .
\end{gathered}
$$

A (3.7) formula megmutatja, hogy $v$ valóban (klasszikus) megoldása a (3.1)-(3.3) problémának, és hogy a $g \in C^{1}(\mathbb{R}), h \in C(\mathbb{R})$ feltételek nem enyhíthetóek.

A $v$ függvény folytonossága nyilvánvalóan következik a (3.7) alakú felírásból. A $v_{t}$ és $v_{x}$ deriváltak létezése és folytonossága szintén a (3.7) alak folyománya, és ezek a következố reprezentációval rendelkeznek:

$$
\begin{aligned}
& v_{t}=\frac{1}{2} \int_{0}^{t} g(\tau)[h(x+a(t-\tau))+h(x-a(t-\tau))] d \tau, \\
& v_{x}=\frac{1}{2 a} \int_{0}^{t} g(\tau)[h(x+a(t-\tau))-h(x-a(t-\tau))] d \tau .
\end{aligned}
$$

Sajnos a másodrendû deriváltak létezése és folytonossága nem vezethetô le ezen reprezentációkból a szokásos érvelés segítségével, hiszen a fentebbi kifejezéseket nem lehet az integráláson belül deriválni. Ellenben használható hasonló gondolatmenet, mint amit a 3.1. Tétel bizonyítása során majd részletesen kifejtünk.

Ezek után lássunk neki a 3.1. Tétel bizonyításának.

Bizonyitás. Mint tudjuk, folytonosan differenciálható $f$ függvény esetén a szokásos Duhamel-elv szolgáltatja a (3.1)-(3.3) kezdeti érték probléma $v(x, t) \in C^{2}\left(\mathbb{R}^{2}\right)$ megoldását, melyre

$$
v(x, t)=\frac{1}{2 a} \int_{0}^{t}\left(\int_{x-a(t-\tau)}^{x+a(t-\tau)} f(\xi, \tau) d \xi\right) d \tau, \quad(x, t) \in \mathbb{R}^{2} .
$$

A bizonyítás alapja, hogy a (3.8) formula értelmes, és egy $v \in C^{2}\left(\mathbb{R}^{2}\right)$ függvényt definiál akkor is, ha csupán $f \in C\left(\mathbb{R}^{2}\right), f_{t} \in C\left(\mathbb{R}^{2}\right)$ simaságot tételezünk fel, a parciális deriváltak kiszámításából pedig majd láthatjuk, hogy meg is oldja a (3.1)-(3.3) problémát.

Lépésenként be fogjuk látni a (3.8) által definiált $v$ függvény $x$, illetve $t$ irány szerinti deriváltjainak létezését és folytonosságát a második rendủekig bezárólag, így eljutva a 
kívánt $v \in C^{2}\left(\mathbb{R}^{2}\right)$ tulajdonságig.

A $v$ függvény folytonossága azonnal következik a (3.8) formulából.

A $v_{x}$ és $v_{t}$ iránymenti deriváltak létezése és folytonossága $t>0$, illetve $t<0$ esetben szintén következik a (3.8) formulából, csakúgy, mint bármely $(x, t) \in \mathbb{R} \times(\mathbb{R} \backslash\{0\})$ esetén az alábbi reprezentációjuk:

$$
v_{x}(x, t)=\frac{1}{2 a} \int_{0}^{t}[f(x+a(t-\tau), \tau)-f(x-a(t-\tau), \tau)] d \tau,
$$

$$
v_{t}(x, t)=\frac{1}{2} \int_{0}^{t}[f(x+a(t-\tau), \tau)+f(x-a(t-\tau), \tau)] d \tau .
$$

Valójában ezen $v_{x}$ és $v_{t}$ deriváltak a $v$ függvény szokásos parciális deriváltjai. A (3.9) és (3.10) alakból a következô tulajdonságok egyból következnek:

$$
\begin{gathered}
v_{x}, v_{t} \in C(\mathbb{R} \times(0, \infty)), \\
v_{x}, v_{t} \in C(\mathbb{R} \times(-\infty, 0)) .
\end{gathered}
$$

Továbbá az is következik a (3.9), (3.10) kifejezésekből, hogy

$$
\begin{array}{ll}
v_{x}(x, t) \rightarrow 0 \quad \text { amint } & t \rightarrow 0+0 \quad \text { vagy } t \rightarrow 0-0, \\
& \\
v_{t}(x, t) \rightarrow 0 \quad \text { amint } & t \rightarrow 0+0 \quad \text { vagy } t \rightarrow 0-0 .
\end{array}
$$

A (3.11) és (3.12) határértékek megfelelnek a $v$ függvény deriváltjának a $t=0$ felületen. Egyrészt a (3.8) formulában $\left.v\right|_{t=0}=0$, és így $\left(\left.v\right|_{t=0}\right)_{x}=0$. Másrészt a $v_{t}$ derivált létezése $t=0$ pontban, és az, hogy $\left.v_{t}\right|_{t=0}=0$ a Lagrange középértéktételból következik:

$$
\frac{v(x, t)-v(x, 0)}{t-0}=v_{t}(x, \theta t) \rightarrow 0, \quad \text { amint } t \rightarrow 0, \quad \theta \in(0,1),
$$

köszönhetően (3.12)-nek.

Tehát ezek a számolások azt mutatják, hogy

$$
v, v_{x}, v_{t} \in C\left(\mathbb{R}^{2}\right)
$$

és (3.3) teljesül.

Most bebizonyítjuk $v$ második deriváltjainak létezését és folytonosságát $t>0$ ese- 
tén.

Kezdjük a $v_{x x}$ deriválttal, ami nem más, mint $v_{x}$ deriváltja az $x$ irány mentén. Behelyettesítve $x_{2}>x_{1}$ értékeket a (3.9) formulába és rögzítve egy $t>0$ időpontot, azt kapjuk, hogy

$$
\frac{v_{x}\left(x_{2}, t\right)-v_{x}\left(x_{1}, t\right)}{x_{2}-x_{1}}=\frac{1}{2 a}\left(I_{1}\left(f, x_{1}, x_{2}, t\right)-I_{2}\left(f, x_{1}, x_{2}, t\right)\right),
$$

ahol

$$
I_{1}\left(f, x_{1}, x_{2}, t\right)=\int_{0}^{t} \frac{f\left(x_{2}+a(t-\tau), \tau\right)-f\left(x_{1}+a(t-\tau), \tau\right)}{x_{2}-x_{1}} d \tau
$$

$$
I_{2}\left(f, x_{1}, x_{2}, t\right)=\int_{0}^{t} \frac{f\left(x_{2}-a(t-\tau), \tau\right)-f\left(x_{1}-a(t-\tau), \tau\right)}{x_{2}-x_{1}} d \tau
$$

Legyen $\delta:=\left(x_{2}-x_{1}\right) / a$. Mivel az $x_{2}$ értéket majd tartatjuk $x_{1}$-hez, így feltehetjük, hogy $\delta<t$. Tekintsük a következô két párhuzamos karakterisztikát:

$$
\begin{gathered}
l_{1}^{+}:=\left\{\left(x_{1}+a(t-\tau), \tau\right), 0 \leq \tau \leq t\right\}, \\
l_{2}^{+}:=\left\{\left(x_{2}+a(t-(\tau+\delta)), \tau+\delta\right),-\delta \leq \tau \leq t-\delta\right\} .
\end{gathered}
$$

Ezeket osszuk fel két-két részre:

$$
\begin{gathered}
l_{1}^{+}=l_{1,1}^{+} \cup l_{1,2}^{+}, \text {ahol } \\
l_{1,1}^{+}:=\left\{\left(x_{1}+a(t-\tau), \tau\right) \equiv A_{1,1}^{+}(\tau), \tau \in[0, t-\delta]\right\}, \\
l_{1,2}^{+}:=\left\{\left(x_{1}+a(t-\tau), \tau\right) \equiv A_{1,2}^{+}(\tau), \tau \in[t-\delta, t]\right\},
\end{gathered}
$$

és hasonlóképp

$$
\begin{gathered}
l_{2}^{+}=l_{2,1}^{+} \cup l_{2,2}^{+}, \text {ahol } \\
l_{2,1}^{+}:=\left\{\left(x_{2}+a(t-(\tau+\delta), \tau+\delta) \equiv A_{2,1}^{+}(\tau), \tau \in[-\delta, 0]\right\},\right. \\
l_{2,2}^{+}:=\left\{\left(x_{2}+a(t-(\tau+\delta)), \tau+\delta\right) \equiv A_{2,2}^{+}(\tau), \tau \in[0, t-\delta]\right\} .
\end{gathered}
$$


Felhasználva ezeket a jelöléseket arra jutunk, hogy

$$
\begin{aligned}
& I_{1}\left(f, x_{1}, x_{2}, t\right)=\frac{1}{x_{2}-x_{1}}\left[\int_{l_{2}^{+}} f d \tau-\int_{l_{1}^{+}} f d \tau\right]= \\
= & \frac{1}{x_{2}-x_{1}}\left[\int_{l_{2,2}^{+}} f d \tau-\int_{l_{1,1}^{+}} f d \tau+\int_{l_{2,1}^{+}} f d \tau-\int_{l_{1,2}^{+}} f d \tau\right] .
\end{aligned}
$$

Vegyük észre, hogy

$$
A_{2,2}^{+}(\tau)=A_{1,1}^{+}(\tau)+(0, \delta), \quad \forall \tau \in[0, t-\delta]
$$

A Lagrange középértéktétel alapján a (3.16) formula jobb oldalán szereplő első két integrálra a következôt kapjuk: ${ }^{1}$

$$
\begin{aligned}
\frac{1}{x_{2}-x_{1}} & {\left[\int_{l_{2,2}^{+}} f d \tau-\int_{l_{1,1}^{+}} f d \tau\right]=\frac{1}{x_{2}-x_{1}}\left[\int_{0}^{t-\delta} f\left(A_{2,2}^{+}(\tau)\right) d \tau-\int_{0}^{t-\delta} f\left(A_{1,1}^{+}(\tau)\right) d \tau\right]=} \\
& =\frac{1}{a} \int_{0}^{t-\delta} \frac{f\left(A_{1,1}^{+}(\tau)+(0, \delta)\right)-f\left(A_{1,1}^{+}(\tau)\right)}{\delta} d \tau=\frac{1}{a} \int_{0}^{t-\delta} f_{t}(D(\tau)) d \tau,
\end{aligned}
$$

egy alkalmas

$$
D(\tau) \in\left(A_{1,1}^{+}(\tau), A_{2,2}^{+}(\tau)\right), \quad \tau \in(0, t-\delta)
$$

függvénnyel. Képezve az $x_{2} \rightarrow x_{1}(\delta \rightarrow 0)$ határátmenetet arra jutunk, hogy

$$
\frac{1}{a} \int_{0}^{t-\delta} f_{t}(D(\tau)) d \tau \rightarrow \frac{1}{a} \int_{0}^{t} f_{t}\left(x_{1}+a(t-\tau), \tau\right) d \tau
$$

Az integrál-középértéktétel szerint létezik olyan $A_{2,1}^{*} \in l_{2,1}^{+}$pont, hogy a (3.16) formula jobb oldalán lévő harmadik tag a következóbe megy át amint $x_{2} \rightarrow x_{1}(\delta \rightarrow 0)$ :

$$
\frac{1}{x_{2}-x_{1}} \int_{l_{2,1}^{+}} f d \tau=\frac{1}{a} \int_{-\delta}^{0} \frac{f\left(A_{2,1}^{+}(\tau)\right)}{\delta} d \tau=\frac{1}{a} f\left(A_{2,1}^{*}\right) \rightarrow \frac{1}{a} f\left(x_{1}+a t, 0\right) .
$$

\footnotetext{
${ }^{1}$ Itt és a továbbiakban az $f_{t}\left(x_{i} \pm a(t-\tau), \tau\right):=f_{t}(x, t) \mid \begin{gathered}x=x_{i} \pm a(t-\tau) \\ t=\tau\end{gathered}$ jelölést fogjuk használni.
} 
Hasonlóképpen a (3.16)-beli utolsó tag esetére, létezik egy olyan $A_{1,2}^{*} \in l_{1,2}^{+}$pont, hogy

$$
\frac{1}{x_{2}-x_{1}} \int_{l_{1,2}^{+}} f d \tau=\frac{1}{a} \int_{t-\delta}^{t} \frac{f\left(A_{1,2}^{+}(\tau)\right)}{\delta} d \tau=\frac{1}{a} f\left(A_{1,2}^{*}\right) \rightarrow \frac{1}{a} f\left(x_{1}, t\right),
$$

amint $x_{2} \rightarrow x_{1}(\delta \rightarrow 0)$.

Összeadva a kiszámolt határértékeket, $x_{2} \rightarrow x_{1}$ esetén azt kaptuk, hogy

$$
I_{1}\left(f, x_{1}, x_{2}, t\right) \rightarrow \frac{1}{a} \int_{0}^{t} f_{t}\left(x_{1}+a(t-\tau), \tau\right) d \tau+\frac{1}{a} f\left(x_{1}+a t, 0\right)-\frac{1}{a} f\left(x_{1}, t\right) .
$$

Az $I_{2}$-re vonatkozó (3.15) formula abban különbözik az $I_{1}$-re vonatkozó (3.14) formulától, hogy benne $x_{2}+a(t-\tau)$ le van cserélve $x_{2}-a(t-\tau)$-ra, $x_{1}+a(t-\tau)$ pedig le van cserélve $x_{1}-a(t-\tau)$-ra. Ennek megfelelően az $I_{2}\left(f, x_{1}, x_{2}, t\right)$ kifejezésnek az $x_{2} \rightarrow x_{1}$ pontnál vett határértékének a kiszámításához az előzôhöz hasonló gondolatmenetet alkalmazhatunk, amennyiben a következô karakterisztikákat (illetve azok szegmenseit) definiáljuk:

$$
\begin{gathered}
l_{1}^{-}=l_{1,1}^{-} \cup l_{1,2}^{-}, \quad l_{2}^{-}=l_{2,1}^{-} \cup l_{2,2}^{-}, \\
l_{1,1}^{-}:=\left\{\left(x_{1}-a(t-\tau), \tau\right) \equiv A_{1,1}^{-}(\tau), \tau \in[0, t-\delta]\right\}, \\
l_{1,2}^{-}:=\left\{\left(x_{1}-a(t-\tau), \tau\right) \equiv A_{1,2}^{-}(\tau), \tau \in[t-\delta, t]\right\}, \\
l_{2,1}^{-}:=\left\{\left(x_{2}-a(t-(\tau+\delta), \tau+\delta) \equiv A_{2,1}^{-}(\tau), \tau \in[-\delta, 0]\right\},\right. \\
l_{2,2}^{-}:=\left\{\left(x_{2}-a(t-(\tau+\delta)), \tau+\delta\right) \equiv A_{2,2}^{-}(\tau), \tau \in[0, t-\delta]\right\},
\end{gathered}
$$

Megismételve a korábbi számolásokat, ezen karakterisztika szegmensek mentén integrálva azt kapjuk, hogy amennyiben $x_{2} \rightarrow x_{1}$, akkor

$$
I_{2}\left(f, x_{1}, x_{2}, t\right) \rightarrow-\frac{1}{a} \int_{0}^{t} f_{t}\left(x_{1}-a(t-\tau), \tau\right) d \tau-\frac{1}{a} f\left(x_{1}-a t, 0\right)+\frac{1}{a} f\left(x_{1}, t\right) .
$$

Összefoglalva az eddigieket, azt kaptuk a $v_{x x}$ jobb oldali deriváltra (tehát $x_{2} \rightarrow x_{1}$ a (3.13) formulában), hogy

$$
\begin{gathered}
v_{x x}\left(x_{1}, t\right)=\frac{1}{2 a^{2}} \int_{0}^{t}\left[f_{t}\left(x_{1}+a(t-\tau), \tau\right)+f_{t}\left(x_{1}-a(t-\tau), \tau\right)\right] d \tau+ \\
+\frac{f\left(x_{1}+a t, 0\right)+f\left(x_{1}-a t, 0\right)}{2 a^{2}}-\frac{1}{a^{2}} f\left(x_{1}, t\right), \quad x_{1} \in \mathbb{R}, t>0 .
\end{gathered}
$$


A $v_{x x}\left(x_{1}, t\right)$ bal oldali derivált kiszámítása $x_{1} \in \mathbb{R}$ és $t>0$ esetén a fentebbiekkel analóg módon történik, csak ki kell cserélni az $\left(x_{2}, x_{1}\right)$ párt az $\left(x_{1}, x_{2}\right)$ párra és figyelembe venni, hogy ekkor $x_{2}-x_{1}<0$.

Abban az esetben, ha $t<0$, helyettesítsük a

$$
t=-\widetilde{t}, \quad \tau=-\widetilde{\tau}, \quad f(\xi, \eta)=\widetilde{f}(\xi,-\eta)
$$

kifejezéseket a (3.14) formulába, mellyel arra jutunk, hogy ekkor

$$
I_{1}\left(f, x_{1}, x_{2}, t\right)=-\int_{0}^{\tilde{t}} \frac{\widetilde{f}\left(x_{2}-a(\tilde{t}-\tilde{\tau}), \widetilde{\tau}\right)-\widetilde{f}\left(x_{1}-a(\tilde{t}-\widetilde{\tau}), \widetilde{\tau}\right)}{x_{2}-x_{1}} d \widetilde{\tau}=-I_{2}\left(\tilde{f}, x_{1}, x_{2}, \widetilde{t}\right)
$$

Mivel $\widetilde{t}>0$, így a már kiszámolt (3.18) határértékból kiindulva, majd visszahelyettesítve a (3.20) kifejezéseket azt kapjuk, hogy ${ }^{2}$

$$
\begin{gathered}
-I_{2}\left(\widetilde{f}, x_{1}, x_{2}, \widetilde{t}\right) \rightarrow \frac{1}{a} \int_{0}^{\widetilde{t}} \widetilde{f}_{\widetilde{t}}\left(x_{1}-a(\widetilde{t}-\widetilde{\tau}), \widetilde{\tau}\right) d \widetilde{\tau}-\frac{1}{a} \widetilde{f}\left(x_{1}-a \widetilde{t}, 0\right)+\frac{1}{a} \widetilde{f}\left(x_{1}, \widetilde{t}\right)= \\
=\frac{1}{a} \int_{0}^{t} f_{t}\left(x_{1}+a(t-\tau), \tau\right) d \tau+\frac{1}{a} f\left(x_{1}+a t, 0\right)-\frac{1}{a} f\left(x_{1}, t\right),
\end{gathered}
$$

amint $x_{2} \rightarrow x_{1}(\delta \rightarrow 0)$. Ez pedig megegyezik azzal, amit $I_{1}\left(f, x_{1}, x_{2}, t\right)$ határértékére kaptunk a $t>0$ esetben.

Hasonlóképpen, $t<0$ esetén vizsgálva a (3.17) kifejezést, (3.15), (3.20) és (3.17) alapján azt kapjuk, hogy $I_{2}\left(f, x_{1}, x_{2}, t\right)=-I_{1}\left(\widetilde{f}, x_{1}, x_{2}, \widetilde{t}\right) \rightarrow-\frac{1}{a} \int_{0}^{t} f_{t}\left(x_{1}-a(t-\tau), \tau\right) d \tau-\frac{1}{a} f\left(x_{1}-a t, 0\right)+\frac{1}{a} f\left(x_{1}, t\right)$, és ez a határérték pedig egybeesik azzal, amit $I_{2}\left(f, x_{1}, x_{2}, t\right)$-re kaptunk, ha $t>0$ és $x_{2} \rightarrow x_{1}(\delta \rightarrow 0)$.

Következésképpen, (3.19) biztosítja a $v_{x x}(x, t)$ derivált létezését, mi több, a következő formulát szolgáltatja rá:

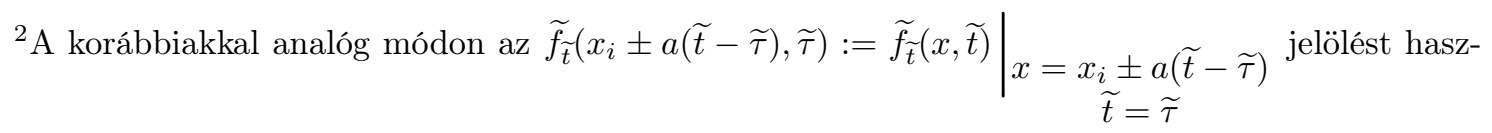
náljuk. 


$$
\begin{aligned}
& v_{x x}(x, t)=\frac{1}{2 a^{2}} \int_{0}^{t}\left[f_{t}(x+a(t-\tau), \tau)+f_{t}(x-a(t-\tau), \tau)\right] d \tau+ \\
& +\frac{f(x+a t, 0)+f(x-a t, 0)}{2 a^{2}}-\frac{1}{a^{2}} f(x, t), \quad x \in \mathbb{R}, t \in \mathbb{R} \backslash\{0\} .
\end{aligned}
$$

Ebból a (3.21) reprezentációból látható a $v_{x x}(x, t)$ folytonossága az $\mathbb{R} \times(-\infty, 0)$ és az $\mathbb{R} \times(0, \infty)$ félsíkokon. Képezve a $t \rightarrow 0$ határátmenetet pedig arra jutunk, hogy

$$
v_{x x}(x, t) \rightarrow 0, \quad x \in \mathbb{R}, t \rightarrow 0+0 \text { vagy } t \rightarrow 0-0,
$$

ami megfelel a

$$
v_{x x}(x, 0):=\left(v_{x}(x, 0)\right)_{x}=0
$$

tulajdonságnak. Ezzel beláttuk, hogy valóban $v_{x x} \in C\left(\mathbb{R}^{2}\right)$.

Most megmutatjuk, hogy $v_{t t}$, mint a $v_{t} \in C\left(\mathbb{R}^{2}\right)$ függvény $t$ szerinti deriváltja létezik és folytonos. Elôször tekintsük a $t>0$ esetet. Ha $t_{2}>t_{1}>0$, és rögzítjük az $x \in \mathbb{R}$ pontot, akkor (3.10) alapján azt kapjuk, hogy

$$
\frac{v_{t}\left(x, t_{2}\right)-v_{t}\left(x, t_{1}\right)}{t_{2}-t_{1}}=\frac{1}{2}\left(I_{3}\left(f, x, t_{1}, t_{2}\right)+I_{4}\left(f, x, t_{1}, t_{2}\right)\right),
$$

ahol az

$$
\begin{aligned}
& I_{3}\left(f, x, t_{1}, t_{2}\right)=\frac{1}{t_{2}-t_{1}}\left[\int_{0}^{t_{2}} f\left(x+a\left(t_{2}-\tau\right), \tau\right) d \tau-\int_{0}^{t_{1}} f\left(x+a\left(t_{1}-\tau\right), \tau\right) d \tau\right] \\
& I_{4}\left(f, x, t_{1}, t_{2}\right)=\frac{1}{t_{2}-t_{1}}\left[\int_{0}^{t_{2}} f\left(x-a\left(t_{2}-\tau\right), \tau\right) d \tau-\int_{0}^{t_{1}} f\left(x-a\left(t_{1}-\tau\right), \tau\right) d \tau\right]
\end{aligned}
$$

jelöléseket használtuk. Legyen $d:=t_{2}-t_{1}$, és vezessük be a következőeket:

$$
\begin{gathered}
l_{3}^{+}:=\left\{\left(x+a\left(t_{1}-\tau\right), \tau\right) \equiv A_{3,3}^{+}, 0 \leq \tau \leq t_{1}\right\}:=l_{3,3}^{+}, \\
l_{4}^{+}:=\left\{\left(x+a\left(t_{2}-(\tau+d)\right), \tau+d\right), \quad-d \leq \tau \leq t_{2}-d\right\} .
\end{gathered}
$$

Most (ellentétben a $v_{x x}$ derivált számításakor történttel) elegendő csak az $l_{4}^{+}$szakaszt tovább bontani: 


$$
\begin{gathered}
l_{4,3}^{+}:=\left\{\left(x+a\left(t_{2}-(\tau+d), \tau+d\right) \equiv A_{4,3}^{+}(\tau), \tau \in[-d, 0]\right\}\right. \\
l_{4,4}^{+}:=\left\{\left(x+a\left(t_{2}-(\tau+d)\right), \tau+d\right) \equiv A_{4,4}^{+}(\tau), \tau \in\left[0, t_{2}-d\right]=\left[0, t_{1}\right]\right\} .
\end{gathered}
$$

A (3.23) formulát a következóképp tudjuk átírni ezen szakaszok mentén vett integrálásokként:

$$
\begin{gathered}
I_{3}\left(f, x, t_{1}, t_{2}\right)=\frac{1}{t_{2}-t_{1}}\left[\int_{l_{4}^{+}} f d \tau-\int_{l_{3}^{+}} f d \tau\right]= \\
=\frac{1}{t_{2}-t_{1}}\left[\int_{l_{4,4}^{+}} f d \tau-\int_{l_{3,3}^{+}} f d \tau+\int_{l_{4,3}^{+}} f d \tau\right] .
\end{gathered}
$$

Vegyük észre, hogy

$$
A_{4,4}^{+}(\tau)=A_{3,3}^{+}(\tau)+(0, d), \quad \forall \tau \in\left[0, t_{1}\right] \text { esetén. }
$$

A Lagrange középértéktétel alapján a (3.25) jobb oldalán található integrálra azt kapjuk, hogy

$$
\begin{gathered}
\frac{1}{t_{2}-t_{1}}\left[\int_{l_{4,4}^{+}} f d \tau-\int_{l_{3,3}^{+}} f d \tau\right]=\frac{1}{t_{2}-t_{1}}\left[\int_{0}^{t_{1}} f\left(A_{4,4}^{+}(\tau)\right) d \tau-\int_{0}^{t_{1}} f\left(A_{3,3}^{+}(\tau)\right) d \tau\right]= \\
=\int_{0}^{t_{1}} \frac{f\left(A_{3,3}^{+}(\tau)+(0, d)\right)-f\left(A_{3,3}^{+}(\tau)\right)}{d} d \tau=\int_{0}^{t_{1}} f_{t}(D(\tau)) d \tau,
\end{gathered}
$$

egy alkalmas

$$
D(\tau) \in\left(A_{3,3}^{+}(\tau), A_{4,4}^{+}(\tau)\right), \quad \tau \in\left(0, t_{1}\right)
$$

függvénnyel. A $t_{2} \rightarrow t_{1}(d \rightarrow 0)$ határátmenet azt eredményezi, hogy

$$
\int_{0}^{t_{1}} f_{t}(D(\tau)) \rightarrow \int_{0}^{t_{1}} f_{t}\left(x+a\left(t_{1}-\tau\right), \tau\right) d \tau
$$

A (3.25) jobb oldalán lévő harmadik tagra pedig alkalmazhatjuk az integrál középértéktételt, így arra jutunk, hogy létezik egy $A_{4,3}^{*} \in l_{4,3}^{+}$pont, hogy

$$
\frac{1}{t_{2}-t_{1}} \int_{l_{4,3}^{+}} f d \tau=\int_{-\delta}^{0} \frac{f\left(A_{4,3}^{+}(\tau)\right)}{d} d \tau=f\left(A_{4,3}^{*}\right) \rightarrow f\left(x+a t_{1}, 0\right), \quad \text { ha } t_{2} \rightarrow t_{1}(d \rightarrow 0) .
$$


Tehát miután a (3.25) jobb oldalán lévő tagokat külön-külön kiszámoltuk, azt kaptuk, hogy

$$
I_{3}\left(f, x, t_{1}, t_{2}\right) \rightarrow \int_{0}^{t_{1}} f_{t}\left(x+a\left(t_{1}-\tau\right), \tau\right) d \tau+f\left(x+a t_{1}, 0\right), \quad \text { ha } t_{2} \rightarrow t_{1} .
$$

Az $I_{4}$-re vonatkozó (3.24) formula abban különbözik az $I_{3}$-ra vonatkozó (3.23) formulától, hogy $x+a\left(t_{2}-\tau\right)$ helyére $x-a\left(t_{2}-\tau\right), x+a\left(t_{1}-\tau\right)$ helyére pedig $x-a\left(t_{1}-\tau\right)$ került. Hasonlóan az $I_{3}\left(f, x, t_{1}, t_{2}\right)$ esetében alkalmazott gondolatmenethez, most a következô karakterisztika szegmenseket definiáljuk:

$$
\begin{gathered}
l_{3}^{-}:=\left\{\left(x-a\left(t_{1}-\tau\right), \tau\right) \equiv A_{3,3}^{-}, 0 \leq \tau \leq t_{1}\right\}:=l_{3,3}^{-}, \\
l_{4}^{-}:=\left\{\left(x-a\left(t_{2}-(\tau+\delta)\right), \tau+\delta\right),-d \leq \tau \leq t_{2}-d\right\} . \\
l_{4,3}^{-}:=\left\{\left(x-a\left(t_{2}-(\tau+d), \tau+d\right) \equiv A_{4,3}^{-}(\tau), \tau \in[-d, 0]\right\},\right. \\
l_{4,4}^{-}:=\left\{\left(x-a\left(t_{2}-(\tau+d)\right), \tau+d\right) \equiv A_{4,4}^{-}(\tau), \tau \in\left[0, t_{2}-d\right]=\left[0, t_{1}\right]\right\},
\end{gathered}
$$

Követve a korábbi okfejtésünket, az $I_{4}\left(f, x, t_{1}, t_{2}\right)$ esetére ezen karakterisztikák mentén integrálva arra jutunk, hogy

$$
I_{4}\left(f, x, t_{1}, t_{2}\right) \rightarrow \int_{0}^{t_{1}} f_{t}\left(x-a\left(t_{1}-\tau\right), \tau\right) d \tau+f\left(x-a t_{1}, 0\right), \quad \text { ha } t_{2} \rightarrow t_{1}(d \rightarrow 0)
$$

Összegezve, ha visszahelyettesítjük a kapott határértékeket (3.22)-be, a $v_{t t}$ jobb oldali deriváltra a

$$
\begin{gathered}
v_{t t}\left(x, t_{1}\right)=\frac{1}{2} \int_{0}^{t_{1}}\left[f_{t}\left(x+a\left(t_{1}-\tau\right), \tau\right)+f_{t}\left(x-a\left(t_{1}-\tau\right), \tau\right)\right] d \tau+ \\
+\frac{f\left(x+a t_{1}, 0\right)+f\left(x-a t_{1}, 0\right)}{2}, \quad 0<t_{1} \in \mathbb{R}, x \in \mathbb{R} .
\end{gathered}
$$

elóállítást nyertük.

Amennyiben $t_{2}<t_{1}<0$, akkor hajtsuk végre a

$$
t=-\widetilde{t}, \quad t_{1}=-\widetilde{t}_{1}, \quad t_{2}=-\widetilde{t}_{2}, \quad \tau=-\widetilde{\tau}, \quad f(\xi, \eta)=\widetilde{f}(\xi,-\eta)
$$


változótranszformációkat a (3.23) formulában. Így azt kapjuk, hogy

$$
\begin{gathered}
I_{3}\left(f, x, t_{1}, t_{2}\right)=\frac{-1}{\widetilde{t}_{1}-\widetilde{t}_{2}}\left[\int_{0}^{\widetilde{t}_{2}} \widetilde{f}\left(x-a\left(\widetilde{t_{2}}-\widetilde{\tau}\right), \widetilde{\tau}\right) d \widetilde{\tau}-\int_{0}^{\widetilde{t}_{1}} \widetilde{f}\left(x-a\left(\widetilde{t_{1}}-\widetilde{\tau}\right), \widetilde{\tau}\right) d \widetilde{\tau}\right]= \\
=I_{4}\left(\widetilde{f}, x, \widetilde{t}_{1}, \widetilde{t}_{2}\right) .
\end{gathered}
$$

Mivel $0<\widetilde{t}_{1}<\widetilde{t}_{2}$, erre alkalmazhatjuk a már kiszámolt (3.26) határátmenetet, majd visszahelyettesítve a (3.29) összefüggéseket megkapjuk, hogy

$$
\begin{aligned}
& I_{4}\left(\widetilde{f}, x, \widetilde{t}_{1}, \widetilde{t}_{2}\right) \rightarrow \int_{0}^{\tilde{t}_{1}} \widetilde{f}_{\widetilde{t}}\left(x-a\left(\widetilde{t}_{1}-\widetilde{\tau}\right), \widetilde{\tau}\right) d \widetilde{\tau}+\widetilde{f}\left(x-a \widetilde{t}_{1}, 0\right)= \\
= & \int_{0}^{t_{1}} f_{t}\left(x+a\left(t_{1}-\tau\right), \tau\right) d \tau+f\left(x+a t_{1}, 0\right), \quad \text { ha } t_{2} \rightarrow t_{1}(d \rightarrow 0),
\end{aligned}
$$

amely eredmény megegyezik azzal, amit $I_{3}\left(f, x, t_{1}, t_{2}\right)$-ra számoltunk a $t>0$ esetben.

Ismét a $t_{2}<t_{1}<0$ esetet vizsgálva, (3.24), (3.29) és (3.26) alapján arra jutunk, hogy

$I_{4}\left(f, x, t_{1}, t_{2}\right)=I_{3}\left(\widetilde{f}, x, \widetilde{t}_{1}, \widetilde{t}_{2}\right) \rightarrow \int_{0}^{t_{1}} f_{t}\left(x-a\left(t_{1}-\tau\right), \tau\right) d \tau+f\left(x-a t_{1}, 0\right), \quad$ ha $t_{2} \rightarrow t_{1}$,

ez a formula pedig egybeesik a $I_{4}\left(f, x, t_{1}, t_{2}\right)$ határértékére vonatkozó formulával a $t>0$ esetben, amint $t_{2} \rightarrow t_{1}(d \rightarrow 0)$.

A $v_{t t}\left(x, t_{1}\right)$ bal oldali derivált vizsgálata - azaz ha $0<t_{2}<t_{1}$ vagy $0>t_{2}>t_{1}-$ analóg módon kezelhetô, csak a fentebbi számításokban a $\left(t_{1}, t_{2}\right)$ párt a $\left(t_{2}, t_{1}\right)$ párra kell cserélni.

Így a $v_{t t}(x, t)$, mint iránymenti derivált létezik, és a (3.28) formula alapján a következô :

$$
\begin{gathered}
v_{t t}(x, t)=\frac{1}{2} \int_{0}^{t}\left[f_{t}(x+a(t-\tau), \tau)+f_{t}(x-a(t-\tau), \tau)\right] d \tau+ \\
+\frac{f(x+a t, 0)+f(x-a t, 0)}{2}, \quad x \in \mathbb{R}, \quad t \in \mathbb{R} \backslash\{0\} .
\end{gathered}
$$

Ez a (3.30) reprezentáció egyben a $v_{t t}(x, t)$ folytonosságát is mutatja amennyiben $(x, t) \in \mathbb{R} \times(0, \infty)$ vagy $(x, t) \in \mathbb{R} \times(-\infty, 0)$, továbbá azt, hogy

$$
v_{t t} \rightarrow f(x, 0), \quad x \in \mathbb{R}, t \rightarrow 0+0 \text { vagy } t \rightarrow 0-0 .
$$


Azaz $v_{t t}$ a $t=0$ egyenes mentén is létezik és folytonos.

A $v_{x t}$ vegyes parciális deriváltra a (3.9) formulából kiindulva azt kapjuk, hogy

$$
\frac{v_{x}\left(x, t_{2}\right)-v_{x}\left(x, t_{1}\right)}{t_{2}-t_{1}}=\frac{1}{2 a}\left(I_{3}\left(f, x, t_{1}, t_{2}\right)-I_{4}\left(f, x, t_{1}, t_{2}\right)\right)
$$

ugyanazon $I_{3}$ és $I_{4}$ kifejezésekkel, amiket (3.23) és (3.24) formulák adnak meg, és amelyek határértékét már kiszámoltuk. Így a $v_{x}$ függvény $t$ szerinti deriváltja a következô:

$$
\begin{gathered}
v_{x t}(x, t)=\frac{1}{2 a} \int_{0}^{t}\left[f_{t}(x+a(t-\tau), \tau)-f_{t}(x-a(t-\tau), \tau)\right] d \tau+ \\
+\frac{f(x+a t, 0)-f(x-a t, 0)}{2 a}, \quad x \in \mathbb{R}, t \in \mathbb{R} \backslash\{0\} .
\end{gathered}
$$

Hasonlóképpen járhatunk el a $v_{t x}$ parciális derivált esetén. Ekkor a (3.10) formulának köszönhetôen

$$
\frac{v_{t}\left(x_{2}, t\right)-v_{t}\left(x_{1}, t\right)}{x_{2}-x_{1}}=\frac{1}{2}\left(I_{1}\left(f, x_{1}, x_{2}, t\right)+I_{2}\left(f, x_{1}, x_{2}, t\right)\right),
$$

ahol $I_{1}$ és $I_{2}$ kifejezés megegyezik (3.14)-mal és (3.15)-gyel. Így a $v_{t}$ függvény $x$ szerinti deriváltja

$$
\begin{gathered}
v_{t x}(x, t)=\frac{1}{2 a} \int_{0}^{t}\left[f_{t}(x+a(t-\tau), \tau)-f_{t}(x-a(t-\tau), \tau)\right] d \tau+ \\
+\frac{f(x+a t, 0)-f(x-a t, 0)}{2 a}, \quad x \in \mathbb{R}, t \in \mathbb{R} \backslash\{0\} .
\end{gathered}
$$

A (3.32) és (3.34) formulák alapján továbbá $v_{x t}=v_{t x} \rightarrow 0$, ha $t \rightarrow 0$, ami összhangban van azzal, hogy

$$
\begin{gathered}
\left.v_{t x}\right|_{t=0}=\left(\left.\left(v_{t}\right)\right|_{t=0}\right)_{x}=0, \\
\left.v_{x t}\right|_{t=0}=\lim _{t \rightarrow 0} \frac{v_{x}(x, t)-v_{x}(x, 0)}{t-0}=\lim _{t \rightarrow 0} v_{x t}(x, \theta t)=0, \quad \theta \in(0,1) .
\end{gathered}
$$

Ez bizonyítja, hogy $v_{x t}, v_{t x} \in C\left(\mathbb{R}^{2}\right)$.

Összegezve az eddigieket, beláttuk, hogy a $v$ függvény deriváltjai léteznek és folytonosak a másodrendúekig bezárólag. Továbbá ha a (3.21) és (3.30) kifejezéseket visszahelyettesítjük, akkor látható, hogy a (3.8) formulával megadott $v$ függvény ki is elégíti a (3.2) egyenletet. A v függvény a (3.1)-(3.3) probléma egyetlen megoldása, hiszen két megoldás különbsége kielégíti a (3.1), (3.3) feltételeket és a homogén (3.2) egyenletet, ami az azonosan nulla függvény. 
Természetesen a 3.1. Tétel kimondása során nem szükséges a $t=0$ kezdô időpontra szorítkoznunk.

3.6. Következmény. $H a f(x, t) \in C\left(\mathbb{R}^{2}\right)$ és az $f_{t}$, mint az $f$ függvény $t$ szerinti deriváltja létezik és $f_{t} \in C\left(\mathbb{R}^{2}\right)$, akkor a (3.1), (3.2) és

$$
\left.v\right|_{t=t_{0}}=\left.v_{t}\right|_{t=t_{0}} \equiv 0
$$

kezdeti érték probléma egyértelmúen megoldható a $C^{2}\left(\mathbb{R}^{2}\right)$-beli függvények körében, és ez a $v(x, t)=v\left(x, t, t_{0}\right)$ megoldás felírható a következố alakban:

$$
v(x, t)=\frac{1}{2 a} \int_{t_{0}}^{t}\left(\int_{x-a(t-\tau)}^{x+a(t-\tau)} f(\xi, \tau) d \xi\right) d \tau, \quad(x, t) \in \mathbb{R}^{2} .
$$

Bizonyítás. Vezessük be a következő transzformációkat:

$$
\breve{v}(x, t)=v\left(x, t+t_{0}\right), \quad \breve{f}(x, t)=f\left(x, t+t_{0}\right) .
$$

Ekkor a következmény állítása azonnal következik a 3.1. Tételből, amint megoldjuk a (3.1)-(3.3) kezdeti érték problémát ezen $\breve{v}$ és $\breve{f}$ függvényekkel.

3.7. Megjegyzés. Megemlítjük még, hogy a 3.1. Tétel (és így az azt felhasználó 4. Fejezetbeli tételek is) igaz marad akkor is, ha

$$
f(x, t) \in C\left(\mathbb{R}^{2}\right), \quad f_{\nu}(x, t):=\frac{\partial f}{\partial \nu} \in C\left(\mathbb{R}^{2}\right),
$$

ahol $f_{\nu}$ az $f$ függvénynek egy $\nu=\left(\nu_{1}, \nu_{2}\right)$ irány szerinti deriváltja, feltéve, hogy $\nu$ transzverzális a karakterisztikákhoz. Ennek a bizonyítása hosszadalmas számolást igényel, ami számos részesetre bomlik a $\nu$ iránytól függóen. Viszont a $v$ megoldás másodrendû deriváltjaira a megengedett $\nu$ irányok mindegyike esetén igazak a következő előállítások:

$$
\begin{gathered}
v_{x x}(x, t)=\frac{1}{2 a}\left[\frac{\nu_{2} f(x+a t, 0)-\nu_{2} f(x, t)+\int_{0}^{t} f_{\nu}(x+a(t-\tau), \tau) d \tau}{\nu_{1}+a \nu_{2}}+\right. \\
\left.+\frac{\left.\nu_{2} f(x-a t, 0)-\nu_{2} f(x, t)+\int_{0}^{t} f_{\nu}(x-a(t-\tau), \tau) d \tau\right]}{a \nu_{2}-\nu_{1}}\right]
\end{gathered}
$$




$$
\begin{aligned}
v_{t x}(x, t)= & v_{x t}(x, t)=\frac{1}{2}\left[\frac{\nu_{2} f(x+a t, 0)-\nu_{2} f(x, t)+\int_{0}^{t} f_{\nu}(x+a(t-\tau), \tau) d \tau}{\nu_{1}+a \nu_{2}}\right. \\
& \left.-\frac{\left.\nu_{2} f(x-a t, 0)-\nu_{2} f(x, t)+\int_{0}^{t} f_{\nu}(x-a(t-\tau), \tau) d \tau\right]}{a \nu_{2}-\nu_{1}}\right], \\
v_{t t}(x, t) & =\frac{1}{2}\left[\frac{a \nu_{2} f(x+a t, 0)+\nu_{1} f(x, t)+a \int_{0}^{t} f_{\nu}(x+a(t-\tau), \tau) d \tau}{\nu_{1}+a \nu_{2}}\right. \\
& \left.+\frac{a \nu_{2} f(x-a t, 0)-\nu_{1} f(x, t)+a \int_{0}^{t} f_{\nu}(x-a(t-\tau), \tau) d \tau}{a \nu_{2}-\nu_{1}}\right] .
\end{aligned}
$$

Ezen eredmény részletes bizonyítását egy késôbbi, elôkészületben lévő dolgozatban szeretnénk közölni.

Végezetül megfogalmazunk egy sejtést.

Sejtés. A 3.1. Tétel általánosítható arra az esetre is, ha az

$$
f(x, t) \in C\left(\mathbb{R}^{2}\right), \quad f_{\nu}(x, t):=\frac{\partial f}{\partial \nu} \in C\left(\mathbb{R}^{2}\right)
$$

feltételben a karakterisztikákra transzverzális $\nu$ irány az $(x, t)$ változó folytonos függvénye, feltéve, hogy a $\nu=\left(\nu_{1}, \nu_{2}\right)$ irányok mindegyike egy és ugyanazon szektorba esik az alábbi három közül:

$$
0 \leq \frac{\nu_{2}}{\nu_{1}}<\frac{1}{a}, \quad-\frac{1}{a}<\frac{\nu_{2}}{\nu_{1}} \leq 0, \quad\left|\frac{\nu_{2}}{\nu_{1}}\right|>\frac{1}{a} .
$$




\section{4. fejezet}

\section{Klasszikus kitüzésû megfigyelési problémák}

Ebben a fejezetben a végtelen rezgő húrral kapcsolatos megfigyelési problémákat tárgyalunk klasszikus kitǔzés esetén.

\subsection{A végtelen rezgő húr problémája külső erôhatás mellett}

Tekintsük a következő kezdeti érték problémát:

$$
\begin{gathered}
u(x, t) \in C^{2}\left(\mathbb{R}^{2}\right) \\
u_{t t}(x, t)-a^{2} u_{x x}(x, t)=f(x, t), \quad(x, t) \in \mathbb{R}^{2}, \quad a>0, \\
\left.u\right|_{t=t_{0}}(x)=\varphi(x),\left.\quad u_{t}\right|_{t=t_{0}}(x)=\psi(x), \quad \varphi \in C^{2}(\mathbb{R}), \quad \psi \in C^{1}(\mathbb{R}) .
\end{gathered}
$$

Amennyiben (az előző fejezetnek megfelelően) $f(x, t)$ folytonos, és az $f_{t}$ iránymenti derivált létezik és folytonos, akkor a (4.1)-(4.3) kezdeti érték probléma u megoldása létezik, egyértelmú és folytonosan függ a kezdeti adatoktól (azaz $u(x, t)$ klasszikus megoldás). 
Ekkor az $u$ megoldást $u_{1}+u_{2}$ alakban állítjuk elő:

$$
\begin{aligned}
u=u_{1}+u_{2} & =\left[\frac{\varphi\left(x-a\left(t-t_{0}\right)\right)+\varphi\left(x+a\left(t-t_{0}\right)\right)}{2}+\frac{1}{2 a} \int_{x-a t}^{x+a t} \psi(s) d s\right]+ \\
& +\frac{1}{2 a} \int_{t_{0}}^{t}\left(\int_{x-a(t-\tau)}^{x+a(t-\tau)} f(\xi, \tau) d \xi\right) d \tau, \quad(x, t) \in \mathbb{R}^{2}
\end{aligned}
$$

ahol $u_{1}$ a homogén rezgő húr megoldása $(\varphi, \psi)$ kezdeti függvények mellett, melyet a közismert D'Alembert formula szolgáltat; $u_{2}$ pedig az inhomogén rezgô húr megoldása homogén kezdeti feltételekkel, mely a Duhamel-elvból származik. Szeretnénk felhívni rá a figyelmet, hogy a (4.4) formula tetszôleges $t \in \mathbb{R}$ időpontban megadja a megoldást, azaz időben előre és visszafele haladva is múködik. Továbbá lényeges, hogy ha ismerjük a végtelen rezgő húr teljes állapotát (pozició és sebesség) valamely időpontban, akkor annak segítségével már a teljes rezgés leírható. Ugyanis tegyük fel, hogy a $g_{1}, g_{2}$ függvények ismertek, amelyekre

$$
\left.u\right|_{t=T_{0}}(x)=g_{1}(x),\left.\quad u_{t}\right|_{t=T_{0}}(x)=g_{2}(x), \quad g_{1} \in C^{2}(\mathbb{R}), g_{2} \in C^{1}(\mathbb{R}),
$$

azaz a $T_{0}$ idôpontban $g_{1}$ és $g_{2}$ írja le a rezgô húr helyzetét, illetve sebességét. Ekkor ha tekintjük a $w(x, t)=u\left(x, t+\left(T_{0}-t_{0}\right)\right)$ eltolást, akkor a $w$ függvény a következő probléma klasszikus megoldása:

$$
\begin{gathered}
w_{t t}(x, t)-a^{2} w_{x x}(x, t)=f\left(x, t+\left(T_{0}-t_{0}\right)\right), \quad(x, t) \in \mathbb{R}^{2}, \quad a>0, \\
\left.w\right|_{t=t_{0}}=g_{1}(x),\left.\quad w_{t}\right|_{t=t_{0}}=g_{2}(x), \quad g_{1} \in C^{2}(\mathbb{R}), g_{2} \in C^{1}(\mathbb{R}) .
\end{gathered}
$$

Erre alkalmazva a (4.4) reprezentációt azt kapjuk, hogy

$$
\begin{aligned}
u(x, t)= & w\left(x, t-\left(T_{0}-t_{0}\right)\right)=\frac{g_{1}\left(x-a\left(t-T_{0}\right)\right)+g_{1}\left(x+a\left(t-T_{0}\right)\right)}{2}+ \\
& +\frac{1}{2 a} \int_{x-a\left(t-T_{0}\right)}^{x+a\left(t-T_{0}\right)} g_{2}(s) d s+\frac{1}{2 a} \int_{T_{0}}^{t}\left(\int_{x-a(t-\tau)}^{x+a(t-\tau)} f(\xi, \tau) d \xi\right) d \tau,
\end{aligned}
$$

mellyel sikeresen megadtuk az $u(x, t)$ függvényt. Emellett ebbe a (4.6) formulába, illetve a deriváltjába behelyettesítve a $t_{0}$ kezdeti időpontot megkapjuk a kezdeti függvényeket 
is, amelyek a következók:

$$
\begin{gathered}
\varphi(x)=\left.u\right|_{t=t_{0}}=\frac{g_{1}\left(x-a\left(t_{0}-T_{0}\right)\right)+g_{1}\left(x+a\left(t_{0}-T_{0}\right)\right)}{2}+\frac{1}{2 a} \int_{x-a\left(t_{0}-T_{0}\right)}^{x+a\left(t_{0}-T_{0}\right)} g_{2}(s) d s+ \\
+\frac{1}{2 a} \int_{T_{0}}^{t_{0}}\left(\int_{x-a\left(t_{0}-\tau\right)}^{x+a\left(t_{0}-\tau\right)} f(\xi, \tau) d \xi\right) d \tau, \\
\frac{a\left[g_{1}^{\prime}\left(x+a\left(t_{0}-T_{0}\right)\right)-g_{1}^{\prime}\left(x-a\left(t_{0}-T_{0}\right)\right)\right]}{2}+\frac{g_{2}\left(x+a\left(t_{0}-T_{0}\right)\right)+g_{2}\left(x-a\left(t_{0}-T_{0}\right)\right)}{2}+ \\
+\frac{1}{2} \int_{T_{0}}^{t_{0}}\left[f\left(x+a\left(t_{0}-\tau\right), \tau\right)+f\left(x-a\left(t_{0}-\tau\right), \tau\right)\right] d \tau .
\end{gathered}
$$

A továbbiakban a megfigyelési probléma megoldása során a célunk a rezgố húr teljes állapotának megadása lesz a két megfigyelési idôpont: $t_{1}, t_{2}$ egyikében, pl. $t=t_{1}$-ben. Amennyiben ez sikerül, akkor egyben a megfigyelési problémát is megoldottuk, hiszen ekkor a fentiek miatt egyszerúen meg tudjuk kapni a keresett kezdeti függvényeket a $t=t_{0}$ idôpontban is. Így a számolások egyszerúsítésének céljából az általánosság megszorítása nélkül feltesszük, hogy a kezdeti idôpont és az egyik megfigyelési idôpont egybeesik, azaz $t_{0}=t_{1}$.

A 4. Fejezet további részében az

$$
\begin{array}{ll}
\left.A_{1}(x) u\right|_{t=t_{1}}+\left.B_{1}(x) u_{t}\right|_{t=t_{1}}=f_{1}(x), & x \in \mathbb{R}, \\
\left.A_{2}(x) u\right|_{t=t_{2}}+\left.B_{2}(x) u_{t}\right|_{t=t_{2}}=f_{2}(x), & x \in \mathbb{R},
\end{array}
$$

megfigyelési feltétel segítségével kitüzött megfigyelési problémát fogjuk megvizsgálni, ahol az $A_{1}, A_{2}, B_{1}, B_{2}$ függvényegyütthatók és az $f_{1}, f_{2}$ megfigyelt állapotok ismertek.

\subsection{Egy speciális eset}

Ebben az alfejezetben azon azon speciális esetet tárgyaljuk, amikor $B_{1} \equiv B_{2} \equiv 0$. Ekkor a következő állítást tudjuk megfogalmazni.

4.1. Tétel. Tegyük fel, hogy a (4.7) feltételben

$$
A_{i}(x) \neq 0, x \in \mathbb{R}, \quad B_{i} \equiv 0, \quad A_{i}, f_{i} \in C^{2}(\mathbb{R}), \quad i=1,2 .
$$

Továbbá legyen $f(x, t) \in C\left(\mathbb{R}^{2}\right)$ és az $f_{t}$, mint az $f$ függvény $t$ irány szerinti deriváltja 
létezzen és $f_{t} \in C\left(\mathbb{R}^{2}\right)$. Ekkor a (4.1)-(4.3) problémához tartozó, (4.7) megfigyelési feltételú problémának létezik $u \in C^{2}\left(\mathbb{R}^{2}\right)$ megoldása.

Amennyiben a (4.7) feltételben

$$
B_{i} \equiv 0, \quad A_{i} \not \equiv 0, \quad A_{i}, f_{i} \in C^{2}(\mathbb{R}), \quad i=1,2,
$$

akkor a (4.1)-(4.3), (4.7) problémának pontosan akkor létezik $u \in C^{2}\left(\mathbb{R}^{2}\right)$ megoldása, ha $f_{1} / A_{1}$ és $f_{2} / A_{2}$ értelmezhetốk, mint $C^{2}(\mathbb{R})$ függvények (azaz $f_{i} / A_{i}, i=1,2$ kiterjeszthetốek a valós számok halmazára, mint $C^{2}$ függvények).

Bizonyitás. Az (i) megkötés mellett a (4.7)-ben szereplő megfigyelési feltételek a

$$
\begin{gathered}
\varphi(x)=\frac{f_{1}(x)}{A_{1}(x)}, \quad x \in \mathbb{R}, \\
\frac{\varphi(x-T)+\varphi(x+T)}{2}+\frac{\Psi(x+T)-\Psi(x-T)}{2 a}+v\left(x, t_{2}\right)=\frac{f_{2}(x)}{A_{2}(x)}, \quad x \in \mathbb{R}
\end{gathered}
$$

alakot nyerik, ahol az áttekinthetőség kedvéért a

$$
T=a\left(t_{2}-t_{1}\right), \quad \Psi(x)=\int_{0}^{x} \psi(s) d s, \quad v(x, t)=\frac{1}{2 a} \int_{t_{1}}^{t}\left(\int_{x-a(t-\tau)}^{x+a(t-\tau)} f(\xi, \tau) d \xi\right) d \tau
$$

jelöléseket használtuk. Figyelembe vettük továbbá, hogy $t_{0}=t_{1}$, így az elsô megfigyelési feltétel valójában a húr kezdőállapotára vonatkozik, így egyszerú osztással megkaphattuk (4.8)-at. A (4.9) formula pedig a második megfigyelési feltételból következik a (4.4) előállítás felhasználásával a $t=t_{2}$ idôpontra.

Amellett, hogy azonnal megkaptuk a keresett $\varphi$ kezdeti pozíciót, a (4.8) formulából az is látszik, hogy $\varphi \in C^{2}(\mathbb{R})$, így csak a $\psi \in C^{1}(\mathbb{R})$ kezdősebesség meghatározása van hátra. Ehhez behelyettesítjük a (4.8) formulát (4.9)-be, ahonnan átrendezés után azt kapjuk, hogy

$$
\Psi(x+T)-\Psi(x-T)=2 a \frac{f_{2}(x)}{A_{2}(x)}-a \frac{f_{1}(x-T)}{A_{1}(x-T)}-a \frac{f_{1}(x+T)}{A_{1}(x+T)}-2 a v\left(x, t_{2}\right):=h(x),
$$

ahol $h(x)$ ismert függvény és $h(x) \in C^{2}(\mathbb{R})$.

Megmutatjuk, hogy a (4.10) egyenletnek létezik $\Psi \in C^{2}(\mathbb{R})$ megoldása. Ahhoz, hogy egy $\Psi \in C^{2}$ függvény teljesítse (4.10)-et az $x=0$ pontban, a következő három 
egyenlőségnek kell teljesülnie:

$$
\begin{gathered}
\Psi(T)-\Psi(-T)=h(0), \\
\Psi^{\prime}(T)-\Psi^{\prime}(-T)=h^{\prime}(0), \\
\Psi^{\prime \prime}(T)-\Psi^{\prime \prime}(-T)=h^{\prime \prime}(0) .
\end{gathered}
$$

Válasszunk egy tetszóleges $\Psi \in C^{2}[-T, T]$ függvényt, ami teljesíti (4.11)-(4.13)-at. A (4.10) egyenlet alapján bármely $\Psi(x)$ függvényérték rekurzívan meghatározható az $x-2 T$, illetve $x+2 T$ pontokban felvett értékéból:

$$
\begin{gathered}
\Psi(x+T)=\Psi(x-T)+h(x), \quad x \in[0,2 T], \\
\Psi(x-T)=\Psi(x+T)-h(x), \quad x \in[-2 T, 0] .
\end{gathered}
$$

Ha eltoljuk az argumentumot, (4.14) és (4.15) rendre ekvivalensek a következő formulákkal:

$$
\begin{gathered}
\Psi(x)=\Psi(x-2 T)+h(x-T), \quad x \in[T, 3 T], \\
\Psi(x)=\Psi(x+2 T)-h(x+T), \quad x \in[-3 T,-T] .
\end{gathered}
$$

Ezzel a választott $\Psi \in C^{2}[-T, T]$ függvényt kiterjesztettük a $[-3 T, 3 T]$ intervallumra. Ezt ismételve, azaz $2 T$ értékkel lépdelve mindkét irányba, a következőeket nyerjük:

$$
\begin{gathered}
\Psi(x)=\Psi(x-2 n T)+\sum_{k=1}^{n} h(x-(2 k-1) T), \\
x \in I_{n}:=[(2 n-1) T,(2 n+1) T], n \in \mathbb{N}, \\
\Psi(x)=\Psi(x+2 n T)-\sum_{k=1}^{n} h(x+(2 k-1) T), \\
x \in I_{-n}:=[(-2 n-1) T,(-2 n+1) T], n \in \mathbb{N} .
\end{gathered}
$$

Mivel a $\Psi(x)$ függvényt $C^{2}$-belinek választottuk a $[-T, T]$ intervallumon, továbbá $h \in C^{2}(\mathbb{R})$, ezért az így kapott $\Psi(x)$ függvény a $2 T$ hosszúságú $I_{n}$ és $I_{-n}$ intervallumok belsejében nyilvánvalóan jól definiált és $C^{2}$-beli.

Bebizonyítjuk, hogy a $\Psi(x)$ függvény az $x=(2 n+1) T, n \in \mathbb{Z}$, csatlakozási pon- 
tokban is jól definiált és kellóképpen sima.

Tetszóleges $0<n \in \mathbb{Z}$ esetén vizsgáljuk meg a $\Psi$ függvényt a $x=(2 n+1) T$ csatlakozási pontban. A folytonosság igazolásához írjuk fel ebben a pontban a féloldali határértékeket a (4.16) formula segítségével:

$$
\begin{aligned}
& \lim _{r \rightarrow 0^{+}} \Psi((2 n+1) T-r)=\lim _{r \rightarrow 0^{+}}\left(\Psi(T-r)+\sum_{k=1}^{n} h(2 k T-r)\right), \\
& \lim _{r \rightarrow 0^{+}} \Psi((2 n+1) T+r)=\lim _{r \rightarrow 0^{+}}\left(\Psi(-T+r)+\sum_{k=0}^{n} h(2 k T+r)\right) .
\end{aligned}
$$

Láthatjuk, hogy a

$$
\lim _{r \rightarrow 0^{+}} \Psi((2 n+1) T+r)=\lim _{r \rightarrow 0^{+}} \Psi((2 n+1) T-r)
$$

egyenlőség pontosan akkor teljesül, ha a (4.11) feltétel fennáll. A (4.17) formula segítségével hasonlóképpen kaphatjuk meg, hogy (4.11) szükséges és elegendő feltétele annak is, hogy $\Psi(x)$ folytonos az $x=(2 n+1) T, 0>n \in \mathbb{Z}$ pontokban.

Amennyiben deriváljuk a (4.16) és (4.17) formula mindkét oldalát $x$ szerint, az elóbbihez hasonló gondolatmenet azt adja, hogy

$$
\lim _{r \rightarrow 0^{+}} \Psi^{\prime}((2 n+1) T+r)=\lim _{r \rightarrow 0^{+}} \Psi^{\prime}((2 n+1) T-r),
$$

azaz $\Psi(x)$ folytonosan differenciálható az $x=(2 n+1) T, n \in \mathbb{Z}$ pontokban pontosan akkor, ha (4.12) teljesül.

Ha kétszer deriváljuk (4.16) és (4.17) mindkét oldalát, majd vesszük a féloldali határértékeket az $x=(2 n+1) T$ pontokban akkor pedig arra jutunk, hogy

$$
\lim _{r \rightarrow 0^{+}} \Psi^{\prime \prime}((2 n+1) T+r)=\lim _{r \rightarrow 0^{+}} \Psi^{\prime \prime}((2 n+1) T-r)
$$

pontosan akkor teljesül, ha (4.13) fennáll. Ez pedig az adott pontban vett kétszer folytonosan differenciálhatóságot jelenti.

Mivel $\Psi$-t úgy választottuk, hogy (4.11)-(4.13) fennálljon, így kaptunk egy olyan $\Psi \in C^{2}(\mathbb{R})$ függvényt, mely kielégíti a (4.10) egyenlőséget. Vagyis a (4.8) által meghatározott $\varphi \in C^{2}(\mathbb{R})$, és a $\psi:=\Psi^{\prime} \in C^{1}(\mathbb{R})$ kezdeti függvényekkel a (4.4) formula segítségével előállított $u$ megoldása a (4.2) húrrezgésegyenletnek kielégíti a (4.7) megfigyelési feltételt az (i) megkötés mellett, azaz megoldja a megfigyelési problémát. A megoldás nem egyértelmú, hiszen a konstrukció során a $\Psi$ függvényt (és ezzel $\psi$-t is) a $[-T, T]$ intervallum belsejében tetszólegesen választhattuk. 
A (ii) megkötés mellett a 4.1. Tétel bizonyítása a következő. Ha valamely $x^{*} \in \mathbb{R}$ esetén $A_{1}\left(x^{*}\right)=0$ vagy $A_{2}\left(x^{*}\right)=0$, akkor a (4.8), (4.9) egyenletrendszer megoldhatóságának szükséges és elegendő feltétele, hogy rendre $f_{1}\left(x^{*}\right)=0$ vagy $f_{2}\left(x^{*}\right)=0$. Amennyiben ez a feltétel teljesül, és az $f_{1}(x) / A_{1}(x), f_{2}(x) / A_{2}(x)$ függvényeket rendre az $x \in \mathcal{M}\left(A_{1}\right), x \in \mathcal{M}\left(A_{2}\right)$ helyeken értelmezzük, ahol

$$
A_{1}(x) \neq 0, \quad \text { ha } x \in \mathcal{M}\left(A_{1}\right), \quad A_{2}(x) \neq 0, \quad \text { ha } x \in \mathcal{M}\left(A_{2}\right) \text {, }
$$

akkor $f_{1}(x) / A_{1}(x)$ és $f_{2}(x) / A_{2}(x)$ rendre kiterjeszthető a $\mathcal{M}\left(A_{1}\right), \mathcal{M}\left(A_{2}\right)$ halmazokról $\mathbb{R}$-re, mint $C^{2}(\mathbb{R})$ függvények. Ekkor a bizonyítás (i) megkötéshez tartozó részét megismételve megkapjuk a keresett $\varphi, \psi$ (és velük együtt az $u$ ) függvényeket.

A (ii) megkötéshez tartozó eset például ha az $A_{1}, A_{2}$ együtthatóknak izolált zéróhelyei vannak, vagy ha egy intervallumon azonosan nullák.

4.2. Megjegyzés. Egy másik lehetôség a (4.10) egyenlet megoldására, ha a $\Psi$ függvényt nem a $[-T, T]$ intervallumon választjuk tetszólegesnek, hanem olyan diszjunkt $\left[c_{i}, d_{i}\right], i \in \mathbb{N}$ intervallumok unióján adjuk meg, $\left.\Psi\right|_{\left[c_{i}, d_{i}\right]} \equiv \Psi_{i}$, amelyekre léteznek olyan $S_{i}$, a (4.16), (4.17)-nek alávetett eltolás transzformációk, hogy az $\left\{S_{i} \Psi_{i}\right\}_{i \in \mathbb{N}}$ rendszer diszjunkt tagokból áll (a grafikonok csatlakozási pontjaitól eltekintve), és

$$
\bigcup S_{i} \Psi_{i} \in C^{2}([-T, T]), \quad \text { és ez a függvény kielégíti (4.11)-(4.13)-at. }
$$

A 4.1. Tételhez hasonló állítások tehetők akkor, amikor a (4.7) megfigyelési feltételben szereplő $A_{1}, A_{2}, B_{1}, B_{2}$ együtthatók közül nem a $B_{1}, B_{2}$ pár azonosan egyenlő nullával. Mivel a számolás menete a fentebbihez hasonló, ezért itt a részletezésétól eltekintünk, de a [18] cikkben megtalálhatóak azok az esetek, amikor $B_{1} \equiv A_{2} \equiv 0$ vagy $A_{1} \equiv A_{2} \equiv 0$.

Mielőtt rátérnénk a végtelen húrra vonatkozó általános esetre, azaz amikor nem túnnek el az együtthatók, terjesszük ki a 4.1. Tétel eredményét félvégtelen húrokra. Ehhez a tükrözések módszerét használjuk.

\subsection{Kiterjesztés félvégtelen húrra}

\subsubsection{A rögzített végpont esete}

Rögzített végpontú félvégtelen húr esetén páratlan kiterjesztésekre lesz szükségünk, ezért tekintsük azt az esetet, amikor a paritások a következóek:

- a (4.2) húrrezgésegyenletben az $f(x, t)$ külső erô páratlan függvény az $x=0$ egyenesre nézve 
- a (4.7) feltételben az $f_{1}(x), f_{2}(x)$ megfigyelt részleges állapotok páratlan függvények, az $A_{1}(x), A_{2}(x)$ együtthatók pedig páros függvények az $x=0$ pontra nézve

- a 4.1. Tétel bizonyítása során a $\Psi(x)$ függvényt válasszuk párosnak a $[-T, T]$ intervallumon.

Ekkor a konstruált $\Psi(x)$ páros lesz az $x=0$ pontra az egész számegyenest tekintve is. Az ehhez a $\Psi$ függvényhez kapcsolódó $u$ megoldása a megfigyelési problémának így pedig páratlan lesz.

Ugyanis tekintsük a (4.16), (4.17) formulákat, és legyen $x \in I_{n}$. Ekkor

$$
\begin{aligned}
& \Psi(x)-\Psi(-x)=\Psi(x-2 n T)-\Psi(-(x-2 n T))+ \\
& +\sum_{k=1}^{n} h(x-(2 k-1) T)+\sum_{k=1}^{n} h(-(x-(2 k-1) T)) .
\end{aligned}
$$

Mivel $v(x, t)$ páratlan amennyiben $f(x, t)$ páratlan az $x=0$ egyenesre, és $f_{1} / A_{1}, f_{2} / A_{2}$ is páratlan függvények, így a (4.10)-ben definiált $h(x)$ függvény is páratlan a valós számok halmazán az $x=0$ pontra nézve. Továbbá $\pm(x-2 n T) \in[-T, T]$ és $\Psi$ páros az $x=0$ pontra a $[-T, T]$ intervallumon, ezért azt kapjuk, hogy (4.18) jobb oldala 0 , azaz $\Psi$ páros a teljes számegyenest tekintve. Ebból pedig az következik, hogy a $\varphi=f_{1} / A_{1}$, $\psi=\Psi^{\prime}$ és $f(x, t)$ páratlan függvényekbool a (4.4) formula segítségével előállított $u$ megoldás szintén páratlan.

Ezenkívül a (4.11), (4.12) és (4.13) feltételek egyszerûsíthetôek amennyiben az elóbbinek megfelelô paritású függvényeket tekintünk. Ahogy említettük, ekkor $h(x) \in$ $\in C^{2}(\mathbb{R})$ páratlan, ami egyben azt is jelenti, hogy $h(0)=0$, így pedig (4.11) automatikusan fennáll, hiszen $\Psi$ páros. Mivel $\Psi^{\prime}$ páratlan, így azt kapjuk, hogy

$$
\Psi^{\prime}(T)=\frac{h^{\prime}(0)}{2}
$$

A $\Psi^{\prime \prime}$ függvény ismét páros, és ez a $h^{\prime \prime}(0)=0$ egyenlóséggel együtt azt jelenti, hogy ekkor (4.13) is teljesül.

Tekintsük a félvégtelen $(x \geq 0)$ rezgő húr egyenletét:

$$
\begin{gathered}
u(x, t) \in C^{2}([0, \infty) \times \mathbb{R}), \\
u_{t t}(x, t)-a^{2} u_{x x}(x, t)=g(x, t), \quad(x, t) \in[0, \infty) \times \mathbb{R}, \quad a>0,
\end{gathered}
$$


ahol

$$
g(x, t) \in C([0, \infty) \times \mathbb{R}), \quad g_{t}(x, t) \in C([0, \infty) \times \mathbb{R}) .
$$

Legyen a végpont rögzített:

$$
u(0, t)=0, \quad t \in \mathbb{R},
$$

és legyenek a megfigyelt részleges állapotok a következôek:

$$
\left.u\right|_{t=t_{1}}=g_{1}(x),\left.\quad u\right|_{t=t_{2}}=g_{2}(x), \quad g_{1}, g_{2} \in C^{2}([0, \infty)) .
$$

4.3. Tétel. A (4.19)-(4.23) megfigyelési problémának létezik u megoldása minden olyan $g_{1}, g_{2}$ és g függvények esetén, amelyek teljesitik a következố illeszkedési feltételt:

$$
g(0, t)=g_{1}(0)=g_{1}^{\prime \prime}(0)=g_{2}(0)=g_{2}^{\prime \prime}(0)=0 .
$$

A megoldás nem egyértelmú, viszont bármely u megoldás felírható a következố alakban:

$$
\begin{gathered}
u(x, t)=\frac{f_{1}\left(x-a\left(t-t_{1}\right)\right)+f_{1}\left(x+a\left(t-t_{1}\right)\right)}{2}+\frac{1}{2 a} \int_{x-a\left(t-t_{1}\right)}^{x+a\left(t-t_{1}\right)} \psi(s) d s+ \\
+\frac{1}{2 a} \int_{t_{1}}^{t}\left(\int_{x-a(t-\tau)}^{x+a(t-\tau)} f(\xi, \tau) d \xi\right) d \tau,
\end{gathered}
$$

ahol a jobb oldalt megszorítjuk $x \geq 0-r a . A z f_{1}$ és $f$ függvények a $g_{1}$ és $g$ függvények páratlan kiterjesztései a valós számok halmazára az $x=0$ pontra, illetve egyenesre nézve, a

$$
\Psi(x)=\int_{0}^{x} \psi(s) d s \in C^{2}(\mathbb{R})
$$

függvény pedig tetszólegesen választható a $[0, T]$ intervallumon, feltéve, hogy $\Psi^{\prime}(0)=0$ és kielégíti $\widetilde{(4.12)}$-ót.

Bizonyítás. Először kiterjesztjük páratlanul a $g, g_{1}$ és $g_{2}$ függvényeket, azaz legyen

$$
f(x, t):=\left\{\begin{array}{cl}
g(x, t), & \text { ha } x \geq 0, \\
-g(-x, t), & \text { ha } x<0,
\end{array} \quad(x, t) \in \mathbb{R}^{2},\right.
$$




$$
\begin{aligned}
& f_{1}(x):=\left\{\begin{array}{cc}
g_{1}(x), & \text { ha } x \geq 0, \\
-g_{1}(-x), & \text { ha } x<0,
\end{array} \quad x \in \mathbb{R},\right. \\
& f_{2}(x):=\left\{\begin{array}{cc}
g_{2}(x), & \text { ha } x \geq 0, \\
-g_{2}(-x), & \text { ha } x<0,
\end{array} \quad x \in \mathbb{R} .\right.
\end{aligned}
$$

A (4.24) feltételnek köszönhetóen $f \in C\left(\mathbb{R}^{2}\right), f_{t} \in C\left(\mathbb{R}^{2}\right)$ és $f_{1}, f_{2} \in C^{2}(\mathbb{R})$.

Az ezekkel az $f, f_{1}, f_{2}$ függvényekkel kitúzött (4.1), (4.2), (4.3), (4.7) (ahol $A_{1} \equiv$ $\left.\equiv A_{2} \equiv 1, B_{1} \equiv B_{2} \equiv 0\right)$ megfigyelési problémát a 4.1. Tétel megoldja. A 4.1. Tétel bizonyításában szereplő $\Psi \in C^{2}$ függvényt a $[-T, T]$ intervallumon párosnak választjuk, és ahogy láttuk ekkor a kapott megoldás páratlan. Ennek a megoldásnak a $[0, \infty) \times \mathbb{R}$-ra való megszorítása szolgáltatja a 4.3. Tételbeli probléma $u$ megoldását.

\subsubsection{A szabad végpont esete}

Ebben a szakaszban tekintsük azt a speciális esetet, amikor:

- a (4.2) egyenletben $f(x, t)$ páros az $x=0$ egyenesre nézve

- a (4.7) feltételben $f_{1}(x), f_{2}(x), A_{1}(x), A_{2}(x)$ páros függvények az $x=0$ pontra nézve

- a 4.1. Tétel bizonyításában szereplő $\Psi(x)$ függvényt pedig válasszuk páratlannak a $[-T, T]$ intervallumon.

Ekkor a 4.1. Tétel bizonyítása során konstruált $\Psi(x), x \in \mathbb{R}$ függvény páratlan lesz az $x=0$ pontra nézve a teljes számegyenest tekintve is. Ebból pedig az következik, hogy az ehhez a $\Psi(x)$ függvényhez tartozó $u$ megoldása a (4.1), (4.2), (4.3), (4.7) megfigyelési problémának páros lesz.

Ennek igazolásához adjuk össze a (4.16) és (4.17) formula megfelelő oldalait:

$$
\begin{aligned}
& \Psi(x)+\Psi(-x)=\Psi(x-2 n T)+\Psi(-(x-2 n T))+ \\
& +\sum_{k=1}^{n} h(x-(2 k-1) T)-\sum_{k=1}^{n} h(-(x-(2 k-1) T)) .
\end{aligned}
$$

A $\pm(x-2 n T)$ érték $[-T, T]$ közötti, ott pedig a $\Psi(x)$ függvényt páratlannak választottuk, továbbá a paritásokra vonatkozó megkötéseink miatt a (4.10)-ben definiált $h(x)$ függvény is páros. Ezek következtében a (4.25) jobb oldala 0, tehát $\Psi(x)$ páratlan a valós számok halmazán az $x=0$ pontra nézve. Ekkor a (4.4) formula, és a páros $f$, illetve páros $\varphi=f_{1} / A_{1}, \psi=\Psi^{\prime}$ függvények segítségével előállított $u$ függvény páros lesz. 
A (4.11), (4.12) és (4.13) feltételek a fentebbi paritású függvények esetén a következő alakra egyszerúsödnek:

$$
\Psi(T)=\frac{h(0)}{2}
$$

$$
\Psi^{\prime \prime}(T)=\frac{h^{\prime \prime}(0)}{2}
$$

miközben a (4.12) feltétel $h^{\prime}(0)=0$ és $\Psi^{\prime}$ párossága miatt automatikusan teljesül.

Ebben a szakaszban Neumann peremérték feltétel mellett tekintjük a félvégtelen rezgő húrt, azaz

$$
u_{x}(0, t)=0, \quad t \in \mathbb{R}
$$

4.4. Tétel. A (4.19), (4.20), (4.21), (4.23), (4.26) megfigyelési problémának létezik $u$ megoldása minden olyan $g_{1}$ és $g_{2}$ függvények mellett, melyek kielégítik a következô illeszkedési feltételt:

$$
g_{1}^{\prime}(0)=g_{2}^{\prime}(0)=0 \text {. }
$$

A megoldás nem egyértelmú, viszont felírható a következó alakban:

$$
\begin{gathered}
u(x, t)=\frac{f_{1}\left(x-a\left(t-t_{1}\right)\right)+f_{1}\left(x+a\left(t-t_{1}\right)\right)}{2}+\frac{1}{2 a} \int_{x-a\left(t-t_{1}\right)}^{x+a\left(t-t_{1}\right)} \psi(s) d s, \\
+\frac{1}{2 a} \int_{t_{1}}^{t}\left(\int_{x-a(t-\tau)}^{x+a(t-\tau)} f(\xi, \tau) d \xi\right) d \tau,
\end{gathered}
$$

ahol a jobb oldalt $x \geq 0$-ra tekintjük. Itt az $f_{1}$ függvény $g_{1}$, az $f(x, t)$ függvény pedig $g(x, t)$ páros kiterjesztése az $x=0$ pontra, illetve egyenesre nézve. A

$$
\Psi(x)=\int_{0}^{x} \psi(s) d s \in C^{2}(\mathbb{R})
$$

függvény tetszólegesen választható a $[0, T]$ intervallumon úgy, hogy teljesitse a $\Psi(0)=$ $=\Psi^{\prime \prime}(0)=0$ egyenlóségeket, továbbá $\widehat{(4.11)}$-et és $\widehat{(4.13)}$-at.

Bizonyítás. Ennek a problémának a megoldásához is a tükrözések módszerét fogjuk 
használni, a 4.1. Tétel állítását alapul véve. Terjesszük ki a $g$, a $g_{1}$ és a $g_{2}$ függvényeket párosan, azaz legyen

$$
\begin{aligned}
& f(x, t):=\left\{\begin{array}{rl}
g(x, t), & \text { ha } x \geq 0, \\
g(-x, t), & \text { ha } x<0,
\end{array} \quad(x, t) \in \mathbb{R}^{2},\right. \\
& f_{1}(x):=\left\{\begin{array}{rl}
g_{1}(x), & \text { ha } x \geq 0, \\
g_{1}(-x), & \text { ha } x<0,
\end{array} \quad x \in \mathbb{R},\right. \\
& f_{2}(x):=\left\{\begin{array}{rl}
g_{2}(x), & \text { ha } x \geq 0, \\
g_{2}(-x), & \text { ha } x<0,
\end{array} \quad x \in \mathbb{R} .\right.
\end{aligned}
$$

Ezután a 4.1. Tétel segítségével megoldjuk a (4.1), (4.2), (4.3), (4.7) ( $A_{1} \equiv A_{2} \equiv$ $\equiv 1, B_{1} \equiv B_{2} \equiv 0$ együtthatók mellett) megfigyelési problémát. A $\Psi$ függvényt a megoldás megkonstruálása során a $[-T, T]$ intervallumon páratlannak választjuk, és ahogy láttuk ekkor a kapott megoldás páros lesz az $x=0$ pontra nézve. Ezt a megoldást megszorítva $[0, \infty) \times \mathbb{R}$ halmazra megkapjuk a 4.4. Tételbeli probléma $u$ megoldását.

\subsection{Az általános megfigyelési feltételek esete}

Térjünk rá arra az esetre, amikor a megfigyelési feltételben az együtthatók nemeltûnôek, azaz amikor valóban a rezgô húr pozíciójának és sebességének egy lineáris kombinációját figyeljük meg, és ez alapján próbáljuk megtalálni a kezdeti helyzetet és sebességet.

4.5. Tétel. Tegyük fel, hogy a (4.7) megfigyelési feltételben

$$
A_{1}(x), A_{2}(x), B_{1}(x), B_{2}(x) \neq 0, x \in \mathbb{R}, \quad A_{1}, A_{2}, B_{1}, B_{2}, f_{1}, f_{2} \in C^{1}(\mathbb{R}) .
$$

Ekkor a (4.1)-(4.3), (4.7) megfigyelési problémának létezik megoldása.

Bizonyítás. A (4.1), (4.2) összes megoldása előáll (4.4) alakban, amit ha $t$ szerint deriválunk azt kapjuk, hogy

$$
\begin{aligned}
& u_{t}(x, t)=a \frac{\varphi^{\prime}\left(x+a\left(t-t_{0}\right)\right)-\varphi^{\prime}\left(x-a\left(t-t_{0}\right)\right)}{2}+ \\
& +\frac{\psi\left(x+a\left(t-t_{0}\right)\right)+\psi\left(x-a\left(t-t_{0}\right)\right)}{2}+v_{t}(x, t) .
\end{aligned}
$$


ahol

$$
v(x, t)=\frac{1}{2 a} \int_{t_{1}}^{t}\left(\int_{x-a(t-\tau)}^{x+a(t-\tau)} f(\xi, \tau) d \xi\right) d \tau .
$$

Helyettesítsük be a $t=t_{2}$ idópontot a (4.4) és (4.28) reprezentációkba, amiket felhasználva a (4.7) megfigyelési feltételre a következô alakot nyerjük:

$$
\begin{gathered}
A_{1}(x) \varphi(x)+B_{1}(x) \psi(x)=f_{1}(x), \\
A_{2}(x)\left(\frac{\varphi(x+T)+\varphi(x-T)}{2}+\frac{1}{2 a} \int_{x-T}^{x+T} \psi(s) d s+v\left(x, t_{2}\right)\right)+ \\
+B_{2}(x)\left(a \frac{\varphi^{\prime}(x+T)-\varphi^{\prime}(x-T)}{2}+\frac{\psi(x+T)+\psi(x-T)}{2}+v_{t}\left(x, t_{2}\right)\right)=f_{2}(x),
\end{gathered}
$$

ahol a $T=a\left(t_{2}-t_{1}\right)$ jelölést használjuk az átláthatóság kedvéért. A (4.29) egyenletból azt kapjuk, hogy

$$
\begin{gathered}
\psi(x)=\frac{f_{1}(x)}{B_{1}(x)}-\frac{A_{1}(x)}{B_{1}(x)} \varphi(x), \quad x \in \mathbb{R}, \\
\psi^{\prime}(x)=\left(\frac{f_{1}(x)}{B_{1}(x)}\right)^{\prime}-\left(\frac{A_{1}(x)}{B_{1}(x)}\right)^{\prime} \varphi(x)-\frac{A_{1}(x)}{B_{1}(x)} \varphi^{\prime}(x), \quad x \in \mathbb{R} .
\end{gathered}
$$

Előbb elosztjuk (4.30) mindkét oldalát az $A_{2}(x)$ függvénnyel, majd deriváljuk mindkét oldalt $x$ szerint, így arra jutunk, hogy

$$
\begin{gathered}
\left(\frac{\varphi(x+T)+\varphi(x-T)}{2}+\frac{1}{2 a} \int_{x-T}^{x+T} \psi(s) d s+v\left(x, t_{2}\right)\right)^{\prime}+ \\
+\left(\frac{B_{2}(x)}{A_{2}(x)}\left(a \frac{\varphi^{\prime}(x+T)-\varphi^{\prime}(x-T)}{2}+\frac{\psi(x+T)+\psi(x-T)}{2}+v_{t}\left(x, t_{2}\right)\right)\right)^{\prime}= \\
=\left(\frac{g_{2}(x)}{A_{2}(x)}\right)^{\prime} .
\end{gathered}
$$

Miután behelyettesítjük (4.31)-et (4.32)-be, a következô másodrendú differenciálegyenletet nyerjük a $\varphi$ függvényre:

$$
\begin{gathered}
D_{1}(x) \varphi^{\prime \prime}(x+T)+D_{2}(x) \varphi^{\prime}(x+T)+D_{3}(x) \varphi(x+T)= \\
=E_{1}(x) \varphi^{\prime \prime}(x-T)+E_{2}(x) \varphi^{\prime}(x-T)+E_{3}(x) \varphi(x-T)+h(x),
\end{gathered} \quad x \in \mathbb{R},
$$

ahol az $E_{i}(x), D_{i}(x), i=1,2,3$ együtthatók és a $h(x)$ függvény ismertek minden $x \in$ $\in \mathbb{R}$ számra. A pontos formula az $E_{i}(x), D_{i}(x), i=1,2,3$ együtthatókra és $h(x)$-re a 
bizonyítás szempontjából nem lényeges ugyan, de a következő alakban lehet kifejezni óket :

$$
\begin{aligned}
D_{1}(x) & =E_{1}(x)=\frac{a B_{2}(x)}{2 A_{2}(x)} \neq 0, \quad x \in \mathbb{R}, \\
D_{2}(x) & =\frac{1}{2}+\left(\frac{a B_{2}(x)}{2 A_{2}(x)}\right)^{\prime}-\frac{B_{2}(x) A_{1}(x+T)}{2 A_{2}(x) B_{1}(x+T)}, \\
E_{2}(x) & =-\frac{1}{2}+\left(\frac{a B_{2}(x)}{2 A_{2}(x)}\right)^{\prime}+\frac{B_{2}(x) A_{1}(x-T)}{2 A_{2}(x) B_{1}(x-T)}, \\
D_{3}(x) & =-\frac{A_{1}(x+T)}{2 a B_{1}(x+T)}-\left(\frac{B_{2}(x)}{A_{2}(x)}\right)^{\prime} \frac{A_{1}(x+T)}{2 B_{1}(x+T)}-\frac{B_{2}(x)}{2 A_{2}(x)}\left(\frac{A_{1}(x+T)}{B_{1}(x+T)}\right)^{\prime}, \\
E_{3}(x) & =-\frac{A_{1}(x-T)}{2 a B_{1}(x-T)}+\left(\frac{B_{2}(x)}{A_{2}(x)}\right)^{\prime} \frac{A_{1}(x-T)}{2 B_{1}(x-T)}+\frac{B_{2}(x)}{2 A_{2}(x)}\left(\frac{A_{1}(x-T)}{B_{1}(x-T)}\right)^{\prime}, \\
h(x): & =\left(-\frac{1}{a}-\left(\frac{B_{2}(x)}{A_{2}(x)}\right)^{\prime}\right)\left(\frac{g_{1}(x+T)}{2 B_{1}(x+T)}-\frac{g_{1}(x-T)}{2 B_{1}(x-T)}\right)- \\
& -\left(v\left(x, t_{2}\right)\right)^{\prime}-\left(\frac{B_{2}(x)}{A_{2}(x)}\right)^{\prime}\left(v_{t}\left(x, t_{2}\right)\right)^{\prime} .
\end{aligned}
$$

A 4.5. Tétel feltételei miatt ezek értelmezettek és folytonosak a valós számok halmazán, továbbá a (4.33) egyenlet fótagjának együtthatója nem 0.

A (4.33) differenciálegyenletet lépésenként fogjuk megoldani, melyhez a következô lemmát fogjuk használni.

4.6. Lemma. Ha adott egy $x_{0} \in \mathbb{R}$ és egy $\Phi_{1} \in C^{2}\left(\left[x_{0}-T, x_{0}+T\right]\right)$ függvény úgy, hogy

$$
\begin{gathered}
D_{1}\left(x_{0}\right) \Phi_{1}^{\prime \prime}\left(x_{0}+T\right)+D_{2}\left(x_{0}\right) \Phi_{1}^{\prime}\left(x_{0}+T\right)+D_{3}\left(x_{0}\right) \Phi_{1}\left(x_{0}+T\right)= \\
=E_{1}\left(x_{0}\right) \Phi_{1}^{\prime \prime}\left(x_{0}-T\right)+E_{2}\left(x_{0}\right) \Phi_{1}^{\prime}\left(x_{0}-T\right)+E_{3}\left(x_{0}\right) \Phi_{1}\left(x_{0}-T\right)+h\left(x_{0}\right),
\end{gathered}
$$

akkor létezik egy $\Phi_{2} \in C^{2}\left(\left[x_{0}+T, x_{0}+3 T\right]\right)$, aminek a segítségével definiált

$$
\varphi(x):= \begin{cases}\Phi_{1}(x), & \text { ha } x \in\left[x_{0}-T, x_{0}+T\right] \\ \Phi_{2}(x), & \text { ha } x \in\left[x_{0}+T, x_{0}+3 T\right]\end{cases}
$$

függvény kielégíti a (4.33) egyenletet minden $x \in\left[x_{0}, x_{0}+2 T\right]$ esetén, továbbá $\varphi \in$ $\in C^{2}\left(\left[x_{0}-T, x_{0}+3 T\right]\right)$.

Bizonyítás. A $\varphi$ függvény ki fogja elégíteni (4.33)-at minden $x \in\left[x_{0}, x_{0}+2 T\right]$-re, ha 
találunk hozzá olyan $\Phi_{2}$ függvényt, amire

$$
\begin{gathered}
D_{1}(x) \Phi_{2}^{\prime \prime}(x+T)+D_{2}(x) \Phi_{2}^{\prime}(x+T)+D_{3}(x) \Phi_{2}(x+T)= \\
=E_{1}(x) \Phi_{1}^{\prime \prime}(x-T)+E_{2}(x) \Phi_{1}^{\prime}(x-T)+E_{3}(x) \Phi_{1}(x-T)+h(x)
\end{gathered}
$$

fennáll minden $x \in\left[x_{0}, x_{0}+2 T\right]$ esetén. Ez a (4.35) egyenlet átírható a következő, $\Phi_{2}$-re vonatkozó másodrendú, lineáris differenciálegyenletre:

$$
\widetilde{D_{1}}(x) \Phi_{2}^{\prime \prime}(x)+\widetilde{D_{2}}(x) \Phi_{2}^{\prime}(x)+\widetilde{D_{3}}(x) \Phi_{2}(x)=\widetilde{h}(x), \quad x \in\left[x_{0}+T, x_{0}+3 T\right]
$$

ahol a jobb oldalon szereplő

$\widetilde{h}(x)=E_{1}(x-T) \Phi_{1}^{\prime \prime}(x-2 T)+E_{2}(x-T) \Phi_{1}^{\prime}(x-2 T)+E_{3}(x-T) \Phi_{1}(x-2 T)+h(x-T)$

függvény ismert és $C\left(\left[x_{0}+T, x_{0}+3 T\right]\right)$-beli, továbbá

$$
\widetilde{D_{1}}(x)=D_{1}(x-T), \quad \widetilde{D_{2}}(x)=D_{2}(x-T), \quad \widetilde{D_{3}}(x)=D_{3}(x-T) .
$$

Jól ismert, hogy a (4.36) típusú differenciálegyenlet egyértelmúen megoldható a

$$
\Phi_{2}\left(x_{0}+T\right)=\Phi_{1}\left(x_{0}+T\right), \quad \Phi_{2}^{\prime}\left(x_{0}+T\right)=\Phi_{1}^{\prime}\left(x_{0}+T\right)
$$

kezdeti feltételek mellett és a $\Phi_{2}$ megoldásra teljesül, hogy $\Phi_{2} \in C^{2}\left(\left[x_{0}+T, x_{0}+3 T\right]\right)$.

$\mathrm{Az}$ ezzel a $\Phi_{2}$ függvénnyel konstruált $\varphi$ függvény kielégíti (4.33)-at minden $x \in\left[x_{0}, x_{0}+2 T\right]$ esetén, és nyilvánvalóan $C^{2}$ simaságú az $\left[x_{0}-T, x_{0}+T\right]$ és az $\left[x_{0}+T, x_{0}+3 T\right]$ intervallumok belsejében. A (4.37) kezdeti feltételek miatt $\varphi$ jól definiált és folytonosan differenciálható az $x_{0}+T$ pontban, így már csak azt kell megmutatnunk, hogy a $\varphi$ függvény kétszer is folytonosan differenciálható $x_{0}+T$-ben, azaz hogy

$$
\lim _{r \rightarrow 0^{+}} \varphi^{\prime \prime}\left(x_{0}+T+r\right)=\lim _{r \rightarrow 0^{-}} \varphi^{\prime \prime}\left(x_{0}+T+r\right) .
$$

Ha használjuk $\varphi$ definícióját, a tényt, hogy $\varphi$ kielégíti (4.33)-at az $x_{0}+T+r$ 
pontokban, és hogy (4.34) fennáll, akkor azt kapjuk, hogy

$$
\begin{gathered}
\lim _{r \rightarrow 0^{+}}\left(\widetilde{D_{1}}\left(x_{0}+T+r\right) \varphi^{\prime \prime}\left(x_{0}+T+r\right)\right)=\lim _{r \rightarrow 0^{+}} \widetilde{h}\left(x_{0}+T+r\right)- \\
-\lim _{r \rightarrow 0^{+}}\left(\widetilde{D_{2}}\left(x_{0}+T+r\right) \varphi^{\prime}\left(x_{0}+T+r\right)\right)-\lim _{r \rightarrow 0^{+}}\left(\widetilde{D_{3}}\left(x_{0}+T+r\right) \varphi\left(x_{0}+T+r\right)\right)= \\
=\widetilde{h}\left(x_{0}+T\right)-\widetilde{D_{2}}\left(x_{0}+T\right) \varphi^{\prime}\left(x_{0}+T\right)-\widetilde{D_{3}}\left(x_{0}+T\right) \varphi\left(x_{0}+T\right)= \\
=\widetilde{h}\left(x_{0}+T\right)-\widetilde{D_{2}}\left(x_{0}+T\right) \Phi_{1}^{\prime}\left(x_{0}+T\right)-\widetilde{D_{3}}\left(x_{0}+T\right) \Phi_{1}\left(x_{0}+T\right)= \\
=\widetilde{D_{1}}\left(x_{0}+T\right) \Phi_{1}^{\prime \prime}\left(x_{0}+T\right)=\lim _{r \rightarrow 0^{-}}\left(\widetilde{D_{1}}\left(x_{0}+T+r\right) \varphi^{\prime \prime}\left(x_{0}+T+r\right)\right) .
\end{gathered}
$$

Vegyük észre, hogy a 4.6. Lemmához hasonlóan a $\Phi_{1} \in C^{2}\left(\left[x_{0}-T, x_{0}+T\right]\right)$ függvényhez létezik olyan $\Phi_{2} \in C^{2}\left(\left[x_{0}-3 T, x_{0}-T\right]\right)$, hogy

$$
\varphi(x):= \begin{cases}\Phi_{1}(x), & \text { ha } x \in\left[x_{0}-T, x_{0}+T\right] \\ \Phi_{2}(x), & \text { ha } x \in\left[x_{0}-3 T, x_{0}-T\right]\end{cases}
$$

kielégíti a (4.33) egyenletet minden $x \in\left[x_{0}-2 T, x_{0}\right]$-ra. Ez az állítás könnyedén következik (4.35) átrendezéséból.

A megfigyelési probléma megoldásához válasszunk olyan $\varphi \in C^{2}([-T, T])$ függvényt, amely $\varphi( \pm T), \varphi^{\prime}( \pm T), \varphi^{\prime \prime}( \pm T)$ függvényértékeire (4.33) fennáll az $x=0$ pontban. Emellett legyen a választott $\varphi \in C^{2}([-T, T])$ olyan, hogy teljesül rá a

$$
\begin{gathered}
\frac{1}{2 a} \int_{-T}^{T} \frac{A_{1}(s)}{B_{1}(s)} \varphi(s) d s= \\
=A_{2}(0)\left(\frac{\varphi(T)+\varphi(-T)}{2}+\frac{1}{2 a} \int_{-T}^{T} \frac{f_{1}(s)}{B_{1}(s)} d s+v\left(0, t_{2}\right)\right)+B_{2}(0)\left(a \frac{\varphi^{\prime}(T)-\varphi^{\prime}(-T)}{2}\right)+ \\
+B_{2}(0)\left(\frac{f_{1}(T)}{2 B_{1}(T)}-\frac{A_{1}(T)}{2 B_{1}(T)} \varphi(T)+\frac{f_{1}(-T)}{2 B_{1}(-T)}-\frac{A_{1}(-T)}{2 B_{1}(-T)} \varphi(-T)+v_{t}\left(0, t_{2}\right)\right)-f_{2}(0),
\end{gathered}
$$

egyenlőség, azaz a $\varphi$ függvény elégítse ki a (4.30) egyenletet az $x=0$-ban. Tetszőleges $\varphi( \pm T), \varphi^{\prime}( \pm T), \varphi^{\prime \prime}( \pm T)$ értékekhez létezik ilyen $\varphi \in C^{2}([-T, T])$ függvény, így ez megtehető. Ekkor a 4.6. Lemma segítségével lépésenként meg tudjuk konstruálni a $\varphi \in$ $\in C^{2}((-\infty, \infty))$ megoldását a (4.29), (4.32) egyenletrendszernek, ahol a hozzá tartozó $\psi$ kezdeti függvényt a (4.31) egyenletból tudjuk kiszámolni:

$$
\psi(x)=\frac{g_{1}(x)}{B_{1}(x)}-\frac{A_{1}(x)}{B_{1}(x)} \varphi(x) .
$$

Mivel a (4.30) is fennáll egy pontban, ezért ez a $(\varphi, \psi)$ egyben a (4.29) és (4.30) egyen- 
letrendszer megoldása is minden $x \in \mathbb{R}$ számra. Továbbá $(\varphi, \psi) \in C^{2} \times C^{1}$, tehát ezzel a $(\varphi, \psi)$ függvénypárral indított rezgó húr (mely a (4.4) reprezentációval elóállítható) megoldja a (4.1), (4.2), (4.3), (4.7) megfigyelési problémát. 


\section{5. fejezet}

\section{Összefoglalás}

A disszertáció húrrezgésekkel kapcsolatos megfigyelési problémák megoldhatóságával, illetve a megoldások simaságával foglalkozik.

Egy ilyen megfigyelési feladat, amikor a rezgó húr több (esetünkben 2) idôpontban megfigyelt részleges állapotát ismerve kíséreljük meg leírni a teljes rezgést, vagy legalább megadni a húr olyan kezdeti pozícióját és sebességét, melyból indulva a megfigyelt állapotok előállnak.

A bevezetés után következő 2. Fejezet általánosított függvények körében kitüzött megfigyelési problémákat tárgyal. Ehhez a [3]-ban is megtalálható $D^{s}(S), s \in \mathbb{R}$ tereket hívjuk segítségül.

Legyen adva egy $\left\{X_{n}(x)\right\}_{n=0}^{\infty}$ teljes ortonormált bázis az $L_{2}(S)$ térben. Tetszóleges valós $s$ szám esetén tekintsük az $X_{n}(x)$ függvények által kifeszített lineáris $D$ alteret, ahol $n \in \mathbb{N}_{0}=\mathbb{N} \bigcup\{0\}, x \in \bar{S}$. Tekintsük ezen a téren a következô euklideszi normát:

$$
\left\|\sum_{n=0}^{\infty} c_{n} X_{n}(x)\right\|_{s}:=\left(\sum_{n=0}^{\infty} n^{2 s}\left|c_{n}\right|^{2}\right)^{\frac{1}{2}} .
$$

Teljessé téve a $D$ teret erre a normára nézve egy Hilbert teret kapunk, melyet $D^{s}$-sel jelölünk. A húrrezgésekkel kapcsolatban mi az $S=(0, l)$ intervallumot használjuk.

A 2.1. Alfejezetben egy, a Klein-Gordon egyenlettel kapcsolatos egyszerúbb megfigyelési problémát vizsgálunk. Erre vonatkozó tételünk a következô:

2.1. Tétel. Tegyük fel, hogy adottak $f_{1}, f_{2}$ megfigyelt állapotok és $t_{1}, t_{2}$ megfigyelési idópontok úgy, hogy

$$
f_{1} \in D^{s+2}, \quad f_{2} \in D^{s+2}, \quad s \in \mathbb{R},
$$

és

$$
t_{2}-t_{1}=\frac{p}{q} \frac{2 l}{a}, \quad p, q \in \mathbb{N}
$$


ahol $p$ és q relativ prímek. Továbbá tegyük fel, hogy

$$
\sin \left(\left(t_{2}-t_{1}\right) \sqrt{\left(\frac{n \pi}{l} a\right)^{2}+c}\right) \neq 0, \quad \forall n \in \mathbb{N} .
$$

Ekkor egyértelmúen meghatározhatók olyan $(\varphi, \psi)=\left(u(x, 0), u_{t}(x, 0)\right) \in D^{s+1} \times D^{s}$ kezdeti függvények, melyekkel indított

$$
u_{t t}(x, t)=a^{2} u_{x x}(x, t)-c u(x, t), \quad(x, t) \in[0, l] \times \mathbb{R}, \quad 0<a, c \in \mathbb{R}
$$

egyenletú,

$$
u(0, t)=0, \quad u(l, t)=0, \quad t \in \mathbb{R}
$$

rögzítésú rezgố húr a $t_{1}, t_{2}$ idốpontokban az

$$
u\left(x, t_{1}\right)=f_{1}(x), \quad u\left(x, t_{2}\right)=f_{2}(x), \quad 0 \leq x \leq l
$$

elöirt pozíciókat veszi fel.

A bizonyítás konstruktív, a kezdeti függvények Fourier soros reprezentációja a bizonyításban megtalálható.

Kutatásunk során késóbb ezt az eredményt sikerült általánosítanunk mind a rezgést leíró egyenletet, mind a peremfeltételeket, mind a megfigyelt állapotokat tekintve. Ez az általánosítás a 2.2. Alfejezetben található meg, mely tétel (ami egyben a 2. Fejezet fố eredménye) a következó megfigyelési problémát oldja meg:

Tekintsük a következô vegyes feladatot ismeretlen $\varphi, \psi$ kezdeti függvényekkel:

$$
\begin{gathered}
u_{t t}=\left(p(x) u_{x}\right)_{x}-q(x) u \equiv L u, \quad(x, t) \in[0, l] \times \mathbb{R}, \quad 0<p, q \in C^{\infty}([0, l]), \\
\left.u\right|_{t=0}=\varphi(x),\left.\quad u_{t}\right|_{t=0}=\psi(x), \\
\mathcal{U}_{i}[u] \equiv \mathcal{U}_{i}\left(\left.u\right|_{x=0},\left.u\right|_{x=l},\left.\quad u_{x}\right|_{x=0},\left.\quad u_{x}\right|_{x=l}\right)=0, \quad i=1,2,
\end{gathered}
$$

ahol $\mathcal{U}_{1}, \mathcal{U}_{2}$ független, önadjungált lineáris kifejezések, az $u, \varphi, \psi$ függvények a $D^{s}$ általánosított függvénytérből származnak.

Tegyük fel, hogy bármely $s \in \mathbb{R}$ és bármely $(\varphi, \psi) \in D^{s+1}(0, l) \times D^{s}(0, l)$ esetén ez a vegyes feladat rendelkezik az alábbi jó tulajdonságokkal:

$$
\exists ! u \text { megoldás és } u \in C\left(D^{s+1}, \mathbb{R}\right) \cap C^{1}\left(D^{s}, \mathbb{R}\right) \cap C^{2}\left(D^{s-1}, \mathbb{R}\right),
$$


továbbá $u$ felírható a következő alakban

$$
\begin{gathered}
u(x, t)=\sum_{n=0}^{\infty}\left[\alpha_{n} \cos \left(\omega_{n} t\right)+\beta_{n} \sin \left(\omega_{n} t\right)\right] X_{n}(x), \quad(x, t) \in[0, l] \times \mathbb{R}, \text { ahol } \\
L X_{n}=-\omega_{n}^{2} X_{n}, \quad \mathcal{U}_{i} X_{n}=0, \quad i=1,2 .
\end{gathered}
$$

Megfigyelési feltételeink a $t_{1}$ és $t_{2}$ időpontokban a pozíció és sebesség valamely ismert, tetszőleges lineáris kombinációját tartalmazzák:

$$
\begin{array}{ll}
\left.A_{1} u\right|_{t=t_{1}}+\left.B_{1} u_{t}\right|_{t=t_{1}}=f_{1}, & \left|A_{1}\right|+\left|B_{1}\right|>0, \\
\left.A_{2} u\right|_{t=t_{2}}+\left.B_{2} u_{t}\right|_{t=t_{2}}=f_{2}, & \left|A_{2}\right|+\left|B_{2}\right|>0,
\end{array}
$$

ahol az $A_{1}, A_{2}, B_{1}, B_{2} \in \mathbb{R}$ együtthatók és az $f_{1}, f_{2}$ függvények adottak.

Legyen

$$
f_{1} \in D^{s+2}, f_{2} \in D^{s+2}, \quad s \in \mathbb{R},
$$

és tegyük fel, hogy léteznek $0<A \in \mathbb{Q}, B \in \mathbb{R}, 0<M_{1} \in \mathbb{R}$ konstansok és $C_{n} \in \mathbb{R} \backslash\{0\}$ sorozat úgy, hogy

$$
\begin{gathered}
\omega_{n}\left(t_{2}-t_{1}\right)+\gamma_{n}-\delta_{n}=n \pi A+B+C_{n}, \\
0<\frac{M_{1}}{n}<\left|C_{n}\right|, \forall n \in \mathbb{N} \quad \text { és } \quad C_{n} \rightarrow 0 \text { amint } n \rightarrow \infty,
\end{gathered}
$$

és

$$
\sin \left(\omega_{n}\left(t_{2}-t_{1}\right)+\gamma_{n}-\delta_{n}\right) \neq 0, \quad n \in \mathbb{N}_{0}
$$

Az itt szereplő $\gamma_{n}, \delta_{n} \in[0,2 \pi)$ szögek az alábbi egyenletek által egyértelmúen meghatározottak:

$$
\begin{aligned}
& \sin \gamma_{n}=\frac{A_{1}}{\sqrt{A_{1}^{2}+B_{1}^{2} \omega_{n}^{2}}}, \quad \cos \gamma_{n}=\frac{B_{1} \omega_{n}}{\sqrt{A_{1}^{2}+B_{1}^{2} \omega_{n}^{2}}}, \\
& \sin \delta_{n}=\frac{A_{2}}{\sqrt{A_{2}^{2}+B_{2}^{2} \omega_{n}^{2}}}, \quad \cos \delta_{n}=\frac{B_{2} \omega_{n}}{\sqrt{A_{2}^{2}+B_{2}^{2} \omega_{n}^{2}}} .
\end{aligned}
$$

2.11. Tétel. Az itt vázolt (1)-(7) megfigyelési problémának létezik pontosan egy $(\varphi, \psi)$ $\in D^{s+1} \times D^{s}$ megoldása.

A 2.3. Alfejezetben a 2.11. Tétel alkalmazhatóságának illusztrálására megadunk három példát a Klein-Gordon egyenlet esetén, különböző peremfeltételek mellett. A 2.3.1. Szakaszban a rögzített végpontú, a 2.3.2. Szakaszban a szabad végpontú, a 2.3.3. Szakaszban a Sturm-Liouville rögzítésú húrt tekintjük. Ezen vizsgálatok során láthatjuk, 
hogy a 2.11. Tétel technikai jellegú feltételei konkrét példa esetén jelentôsen egyszerüsödhetnek, vagy akár automatikusan teljesülhetnek. A 2.3.4. Szakaszban megnézzük mi történik, ha a $t_{1}, t_{2}$ megfigyelési idôpontokra nem teszünk megszorításokat a 2.11. Tételben.

A 3. Fejezetben a Duhamel-elv egy új változatát mutatjuk be végtelen rezgó húr esetére, amely a következő:

3.1. Tétel. Amennyiben $f(x, t) \in C\left(\mathbb{R}^{2}\right)$ és az $f$ függvény $t$ irány szerinti $f_{t}$ deriváltja létezik, továbbá $f_{t} \in C\left(\mathbb{R}^{2}\right)$, akkor a

$$
\begin{gathered}
v(x, t) \in C^{2}\left(\mathbb{R}^{2}\right), \\
v_{t t}(x, t)-a^{2} v_{x x}(x, t)=f(x, t), \quad(x, t) \in \mathbb{R}^{2}, \\
\left.v\right|_{t=0}=\left.v_{t}\right|_{t=0} \equiv 0
\end{gathered}
$$

kezdeti érték problémának van megoldása. A megoldás egyértelmú.

A szokásos kitúzés $f(x, t) \in C^{1}\left(\mathbb{R}^{2}\right)$ simasági feltételét élesíti ez a tétel. A $v$ megoldás felírató a következő alakban:

$$
v(x, t)=\frac{1}{2 a} \int_{0}^{t}\left(\int_{x-a(t-\tau)}^{x+a(t-\tau)} f(\xi, \tau) d \xi\right) d \tau, \quad(x, t) \in \mathbb{R}^{2} .
$$

Ez a reprezentáció megegyezik azzal, amit a szokásos kitúzés esetén kapunk. A bizonyítás alapja az, hogy az így definiált függvény értelmezve van és $C^{2}$-beli akkor is, ha csak az általunk tett enyhébb megkötéseket tesszük az $f$ erőfüggvényre.

A 4. Fejezetben klasszikus eszközöket alkalmazunk megfigyelési problémák vizsgálatára, s eközben a minél élesebb állítások megfogalmazásához felhasználjuk az elôző fejezet eredményét. Itt elsősorban végtelen rezgő húrral kapcsolatos megfigyelési problémákat vizsgálunk, de a 4.3.1. és 4.3.2. Szakaszokban a tükrözések módszerének segítségével kitekintünk a félvégtelen rezgő húrok esetére is. A fejezet fố tétele a következő:

4.5. Tétel. Tekintsük az

$$
\begin{gathered}
u(x, t) \in C^{2}\left(\mathbb{R}^{2}\right) \\
u_{t t}(x, t)-a^{2} u_{x x}(x, t)=f(x, t), \quad(x, t) \in \mathbb{R}^{2}, \quad a>0,
\end{gathered}
$$

módon megadott húrrezgést, ahol $f(x, t)$ folytonos, és az $f_{t}$ iránymenti derivált létezik 
és folytonos. A megfigyelt részleges állapotokat pedig a

$$
\begin{array}{ll}
\left.A_{1}(x) u\right|_{t=t_{1}}+\left.B_{1}(x) u_{t}\right|_{t=t_{1}}=f_{1}(x), & x \in \mathbb{R}, \\
\left.A_{2}(x) u\right|_{t=t_{2}}+\left.B_{2}(x) u_{t}\right|_{t=t_{2}}=f_{2}(x), & x \in \mathbb{R},
\end{array}
$$

feltételek irják le, ahol az adott együtthatókra és jobb oldalakra teljesül, hogy

$$
A_{1}(x), A_{2}(x), B_{1}(x), B_{2}(x) \neq 0, x \in \mathbb{R}, \quad A_{1}, A_{2}, B_{1}, B_{2}, f_{1}, f_{2} \in C^{1}(\mathbb{R}) .
$$

Az igy kitúzött megfigyelési problémának létezik megoldása, azaz találhatóak olyan

$$
\left.u\right|_{t=t_{0}}(x)=\varphi(x),\left.\quad u_{t}\right|_{t=t_{0}}(x)=\psi(x), \quad \varphi \in C^{2}(\mathbb{R}), \quad \psi \in C^{1}(\mathbb{R})
$$

kezdeti függvények, amikkel indított húrrezgés során a megfigyelt állapotok elóállnak. A megoldás nem egyértelmú.

Az értekezés a szerző következő négy publikációján alapul:

- Szijártó, A., Hegedûs, J., Observation problems posed for the Klein-Gordon equation, E. J. Qualitative Theory of Differential Equations, 7 (2012), 1-13.

- Szijártó, A., Hegedús, J., Observability of string vibrations, E. J. Qualitative Theory of Differential Equations, 77 (2013), 1-16.

- Szijártó, A., Hegedûs, J., Classical solutions to observation problems for infinite strings under minimally smooth force, Acta Sci. Math., 81 (2015), 503-526.

- Szijártó, A., Hegedús, J., Vibrating infinite string under general observation conditions and minimally smooth force, E. J. Qualitative Theory of Differential Equations, közlésre benyújtva 


\section{6. fejezet}

\section{Summary}

This thesis investigates the solvability of observation problems related to vibrating strings, and the smoothness of their solutions.

An observation problem is, when we observe the partial state of the string in multiple time instants (in our cases, two time instants), and we try to describe the whole vibration process, or at least give such initial position and speed of the string, from which the observed states are reproduced.

Chapter 2 studies observation problems appointed among generalized functions. For this purpose, we use the definition of the spaces $D^{s}(S), s \in \mathbb{R}$ given in [3].

Let the system $\left\{X_{n}(x)\right\}_{n=0}^{\infty}$ be a complete orthonormal basis in $L_{2}(S)$. Given arbitrary real number $s$, we consider on the linear span $D$ of the functions $X_{n}(x), n \in \mathbb{N}_{0}=$ $=\mathbb{N} \bigcup\{0\}, x \in \bar{S}$, the following Euclidean norm:

$$
\left\|\sum_{n=0}^{\infty} c_{n} X_{n}(x)\right\|_{s}:=\left(\sum_{n=0}^{\infty} n^{2 s}\left|c_{n}\right|^{2}\right)^{\frac{1}{2}} .
$$

Completing $D$ with respect to this norm, we obtain a Hilbert space denoted by $D^{s}$. We use the notation $S=(0, l)$ associated with string vibrations.

The subject of Section 2.1 is a somewhat simple observation problem related to the Klein-Gordon equation. Our statement is the following:

Theorem 2.1. Let the given observed states $f_{1}, f_{2}$ and the observation instants $t_{1}, t_{2}$ be such that

$$
f_{1} \in D^{s+2}, \quad f_{2} \in D^{s+2}, \quad s \in \mathbb{R},
$$

and

$$
t_{2}-t_{1}=\frac{p}{q} \frac{2 l}{a}, \quad p, q \in \mathbb{N},
$$


where $p$ and $q$ are relative primes. Moreover let us suppose, that

$$
\sin \left(\left(t_{2}-t_{1}\right) \sqrt{\left(\frac{n \pi}{l} a\right)^{2}+c}\right) \neq 0, \quad \forall n \in \mathbb{N}
$$

Then the initial functions $(\varphi, \psi)=\left(u(x, 0), u_{t}(x, 0)\right) \in D^{s+1} \times D^{s}$ can be uniquely determined, such that the corresponding solution of the equation

$$
u_{t t}(x, t)=a^{2} u_{x x}(x, t)-c u(x, t), \quad(x, t) \in[0, l] \times \mathbb{R}, \quad 0<a, c \in \mathbb{R}
$$

with boundary conditions

$$
u(0, t)=0, u(l, t)=0, \quad t \in \mathbb{R}
$$

will satisfy the observation condition

$$
u\left(x, t_{1}\right)=f_{1}(x), \quad u\left(x, t_{2}\right)=f_{2}(x), \quad 0 \leq x \leq l .
$$

The proof is constructive, the Fourier series representation of the initial functions can be found in the proof.

During our research, we managed to generalize this result in terms of each the equation describing the vibration, the boundary conditions and the observed states. This generalization can be found in Section 2.2, and it solves the following observation problem (which is the main result of Chapter 2):

Consider the following mixed problem with unknown initial functions $\varphi, \psi$ :

$$
\begin{gathered}
u_{t t}=\left(p(x) u_{x}\right)_{x}-q(x) u \equiv L u, \quad(x, t) \in[0, l] \times \mathbb{R}, \quad 0<p, q \in C^{\infty}([0, l]), \\
\left.u\right|_{t=0}=\varphi(x),\left.\quad u_{t}\right|_{t=0}=\psi(x), \\
\mathcal{U}_{i}[u] \equiv \mathcal{U}_{i}\left(\left.u\right|_{x=0},\left.u\right|_{x=l},\left.\quad u_{x}\right|_{x=0},\left.\quad u_{x}\right|_{x=l}\right)=0, \quad i=1,2,
\end{gathered}
$$

where $\mathcal{U}_{1}, \mathcal{U}_{2}$ independent, self-adjoint linear expressions, and the functions $u, \varphi, \psi$ are from the generalized function space $D^{s}$.

Let us suppose, that for every $s \in \mathbb{R}$ and for every $(\varphi, \psi) \in D^{s+1}(0, l) \times D^{s}(0, l)$, this mixed problem possesses the following good properties:

$$
\exists ! u \text { solution and } u \in C\left(D^{s+1}, \mathbb{R}\right) \cap C^{1}\left(D^{s}, \mathbb{R}\right) \cap C^{2}\left(D^{s-1}, \mathbb{R}\right),
$$


and $u$ can be written in the following form:

$$
\begin{gathered}
u(x, t)=\sum_{n=0}^{\infty}\left[\alpha_{n} \cos \left(\omega_{n} t\right)+\beta_{n} \sin \left(\omega_{n} t\right)\right] X_{n}(x), \quad(x, t) \in[0, l] \times \mathbb{R}, \text { where } \\
L X_{n}=-\omega_{n}^{2} X_{n}, \quad \mathcal{U}_{i} X_{n}=0, \quad i=1,2 .
\end{gathered}
$$

Our observation conditions are some known linear combination of the position and the speed of the string at the time instants $t_{1}$ and $t_{2}$ :

$$
\begin{array}{ll}
\left.A_{1} u\right|_{t=t_{1}}+\left.B_{1} u_{t}\right|_{t=t_{1}}=f_{1}, & \left|A_{1}\right|+\left|B_{1}\right|>0, \\
\left.A_{2} u\right|_{t=t_{2}}+\left.B_{2} u_{t}\right|_{t=t_{2}}=f_{2}, & \left|A_{2}\right|+\left|B_{2}\right|>0,
\end{array}
$$

where the coefficients $A_{1}, A_{2}, B_{1}, B_{2}$ and the functions $f_{1}, f_{2}$ are given.

Let

$$
f_{1} \in D^{s+2}, f_{2} \in D^{s+2}, \quad s \in \mathbb{R},
$$

and assume, that there are constants $0<A \in \mathbb{Q}, B \in \mathbb{R}, 0<M_{1} \in \mathbb{R}$ and a series $C_{n} \in \mathbb{R} \backslash\{0\}$ such that

$$
\begin{gathered}
\omega_{n}\left(t_{2}-t_{1}\right)+\gamma_{n}-\delta_{n}=n \pi A+B+C_{n}, \\
0<\frac{M_{1}}{n}<\left|C_{n}\right|, \forall n \in \mathbb{N} \quad \text { and } \quad C_{n} \rightarrow 0 \text { as } n \rightarrow \infty,
\end{gathered}
$$

and

$$
\sin \left(\omega_{n}\left(t_{2}-t_{1}\right)+\gamma_{n}-\delta_{n}\right) \neq 0, \quad n \in \mathbb{N}_{0}
$$

Here the angles $\gamma_{n}, \delta_{n} \in[0,2 \pi)$ are uniquely determined by the following relationships:

$$
\begin{aligned}
& \sin \gamma_{n}=\frac{A_{1}}{\sqrt{A_{1}^{2}+B_{1}^{2} \omega_{n}^{2}}}, \quad \cos \gamma_{n}=\frac{B_{1} \omega_{n}}{\sqrt{A_{1}^{2}+B_{1}^{2} \omega_{n}^{2}}}, \\
& \sin \delta_{n}=\frac{A_{2}}{\sqrt{A_{2}^{2}+B_{2}^{2} \omega_{n}^{2}}}, \quad \cos \delta_{n}=\frac{B_{2} \omega_{n}}{\sqrt{A_{2}^{2}+B_{2}^{2} \omega_{n}^{2}}} .
\end{aligned}
$$

Theorem 2.11. The observation problem (1)-(7) described above has a unique solution $(\varphi, \psi) \in D^{s+1} \times D^{s}$.

In Section 2.3, we give three examples to illustrate the applicability of Theorem 2.11 in the case of the Klein-Gordon equation with various boundary conditions. We consider the vibrating string with fixed ends in Subsection 2.3.1, with free ends in Subsection 
2.3.2, and with Sturm-Liouville boundary condition in Subsection 2.3.3. During these considerations we can see, that the rather technical conditions of Theorem 2.11 can be significantly simplified or they even automatically hold in certain cases. In Subsection 2.3.4 we investigate the case when we doesn't make any restrictions to the observation instants $t_{1}$ and $t_{2}$ in Theorem 2.11 .

In Chapter 3 we introduce a new version of Duhamel's principle for the infinite vibrating string, which is the following:

Theorem 3.1. If $f(x, t) \in C\left(\mathbb{R}^{2}\right)$ and the directional derivative $f_{t}$ of $f$ along $t$ exists and $f_{t} \in C\left(\mathbb{R}^{2}\right)$, then the problem

$$
\begin{gathered}
v(x, t) \in C^{2}\left(\mathbb{R}^{2}\right), \\
v_{t t}(x, t)-a^{2} v_{x x}(x, t)=f(x, t), \quad(x, t) \in \mathbb{R}^{2}, \\
\left.v\right|_{t=0}=\left.v_{t}\right|_{t=0} \equiv 0
\end{gathered}
$$

can be uniquely solved.

This theorem sharpens the smoothness condition $f(x, t) \in C^{1}\left(\mathbb{R}^{2}\right)$ of the classical result. The solution $v$ can be written in the following form:

$$
v(x, t)=\frac{1}{2 a} \int_{0}^{t}\left(\int_{x-a(t-\tau)}^{x+a(t-\tau)} f(\xi, \tau) d \xi\right) d \tau, \quad(x, t) \in \mathbb{R}^{2}
$$

This representation corresponds to the one in the usual setting. The base of the proof is that the function defined by this expression is well-defined and from $C^{2}$ even with our weaker condition for the function $f$.

In Chapter 4, we utilize classical tools for investigating observation problems. To formulate as sharp statements as possible, we use the result of the previous chapter. Here we primarily study observation problems related to the infinite vibrating string, but in Subsections 4.3.1 and 4.3.2 we consider the case of half-infinite strings with the help of the reflection method. The main result of the chapter is the following:

Theorem 4.5. Consider the problem of the infinite vibrating string given by

$$
\begin{gathered}
u(x, t) \in C^{2}\left(\mathbb{R}^{2}\right) \\
u_{t t}(x, t)-a^{2} u_{x x}(x, t)=f(x, t), \quad(x, t) \in \mathbb{R}^{2}, \quad a>0,
\end{gathered}
$$


where $f(x, t)$ is continuous, and the directional derivative $f_{t}$ exists and $f_{t} \in C\left(\mathbb{R}^{2}\right)$. The observed partial states of the string are described by the conditions

$$
\begin{array}{ll}
\left.A_{1}(x) u\right|_{t=t_{1}}+\left.B_{1}(x) u_{t}\right|_{t=t_{1}}=f_{1}(x), & x \in \mathbb{R}, \\
\left.A_{2}(x) u\right|_{t=t_{2}}+\left.B_{2}(x) u_{t}\right|_{t=t_{2}}=f_{2}(x), & x \in \mathbb{R},
\end{array}
$$

where the given coefficients and right-hand sides satisfy

$$
A_{1}(x), A_{2}(x), B_{1}(x), B_{2}(x) \neq 0, x \in \mathbb{R}, \quad A_{1}, A_{2}, B_{1}, B_{2}, f_{1}, f_{2} \in C^{1}(\mathbb{R}) .
$$

This observation problem can be solved, namely there can be found initial functions

$$
\left.u\right|_{t=t_{0}}(x)=\varphi(x),\left.\quad u_{t}\right|_{t=t_{0}}(x)=\psi(x), \quad \varphi \in C^{2}(\mathbb{R}), \quad \psi \in C^{1}(\mathbb{R}),
$$

such that the corresponding vibration described by $u(x, t)$ attain the observed states. The solution is not unique.

The dissertation is based on the following four papers of the author:

- Szijártó, A., Hegedús, J., Observation problems posed for the Klein-Gordon equation, E. J. Qualitative Theory of Differential Equations, 7 (2012), 1-13.

- Szijártó, A., Hegedús, J., Observability of string vibrations, E. J. Qualitative Theory of Differential Equations, 77 (2013), 1-16.

- Szijártó, A., Hegedús, J., Classical solutions to observation problems for infinite strings under minimally smooth force, Acta Sci. Math., 81 (2015), 503-526.

- Szijártó, A., Hegedús, J., Vibrating infinite string under general observation conditions and minimally smooth force, E. J. Qualitative Theory of Differential Equations, submitted 


\section{Köszönetnyilvánítás}

Mindenekelőtt szeretnék köszönetet mondani dr. Hegedûs Jenônek, akinek a támogatására, tanácsaira és bátorítására az elmúlt években közösen végzett kutatómunka és ezen disszertáció megírása során is mindig számíthattam.

Szeretnék továbbá köszönetet mondani dr. Móricz Ferencnek, akihez szintén bármikor fordulhattam, és aki javaslataival, hasznos észrevételeivel rengeteget segített a disszertáció elkészüléséhez vezető úton.

Ezenkívül köszönettel tartozok a Bolyai Intézet oktatóinak és munkatársainak a remek munkakörülmények és a jó munkahelyi légkör biztosításáért. 


\section{Irodalomjegyzék}

[1] Horváth, M., Vibrating strings with free ends, Acta Math. Hungar, 51 (1988), 171-180.

[2] Joó, I., On the vibration of a string, Studia Sci. Math. Hungar, 22 (1987), 1-9.

[3] Komornik, V., Exact controllability and stabilization. The multiplier method, Research in Applied Mathematics 36, Chichester: Wiley, Paris: Masson, 1994.

[4] Lions, J. L., Magenes, E., Problèmes aux limites non homogenès et applications I-III, Dunod, Paris, 1968-1970.

[5] Lions, J. L., Exact controllability, stabilization and perturbations for distributed systems, SIAM Rev. 30 (1988), 1-68.

[6] Il'in, V. A., Boundary control of the vibration process at two ends, Dokl. Acad. Nauk 369:5 (1999), 592-596.

[7] Moiseev, E. I., Kholomeeva, A. A., Optimal boundary displacement control of string vibrations with nonlocal oddness condition of the first kind, Differential Equations $46: 11$ (2010), 1624-1630.

[8] Il'in, V. A., Moiseev, E. I., Optimization of boundary controls of string vibrations, Uspekhi Mat. Nauk 60:6 (2005), 89-114.

[9] Romanov, I. V., Control of plate oscillations by boundary forces (in Russian), Vestnik Moskov. Univ. Ser. I Mat. Mekh., 2 (2011), 3-9; translation in Moscow Univ. Math. Bull. 66:2 (2011), 53-59.

[10] Romanov, I. V., Exact control of the oscillations of a rectangular plate by boundary forces (in Russian), Vestnik Moskov. Univ. Ser. I Mat. Mekh., 4 (2011), 49-53; translation in Moscow Univ. Math. Bull. 66:4 (2011), 166-170.

[11] Komornik, V., Loreti, P., Fourier series in control theory, Springer Monographs in Mathematics, Springer-Verlag, New York, 2005. 
[12] Znamenskaya, L. N., State observability of elastic string vibrations under the boundary conditions of the first kind, Differential Equations, 46 (2010), 748-752.

[13] Szijártó, A., Parciális differenciálegyenletek: kiegészító fejezetek, diplomamunka, Szeged, 2010.

[14] Szijártó, A., Hegedûs, J., Observation problems posed for the Klein-Gordon equation, E. J. Qualitative Theory of Differential Equations, 7 (2012), 1-13.

[15] Szijártó, A., Hegedús, J., Observability of string vibrations, E. J. Qualitative Theory of Differential Equations, 77 (2013), 1-16.

[16] Vest, A., Observation of vibrating systems at different time instants, E. J. Qualitative Theory of Differential Equations, 14 (2014), 1-14.

[17] Szijártó, A., Hegedûs, J., Classical solutions to observation problems for infinite strings under minimally smooth force, Acta Sci. Math., 81 (2015), 503-526.

[18] Szijártó, A., Hegedús, J., Vibrating infinite string under general observation conditions and minimally smooth force, E. J. Qualitative Theory of Differential Equations, közlésre benyújtva

[19] Egorov, A. I., On the observability of elastic vibration of a beam, Zh. Vychisl. Mat. Mat. Fiz. 48:6 (2008), 967-973.

[20] Komornik, V., Loreti, P., Multiple-point internal observability of membranes and plates, Applicable Analysis 90:10 (2011), 1545-1555.

[21] Levitan, B. M., Sargsjan, I. S., Introduction to spectral theory, Nauka, Moscow, 1970. English translation: Translations of Mathematical Monographs, Vol. 39. American Mathematical Society, Providence, R.I., 1975. 